\title{
Testing and Characterization of Engineered Forms of Monosodium Titanate (MST)
}

\author{
K. M. L. Taylor-Pashow \\ C. A. Nash \\ D. T. Hobbs
}

May 2012

Savannah River National Laboratory Savannah River Nuclear Solutions, LLC Aiken, SC 29808

Prepared for the U.S. Department of Energy under contract number DE-AC09-08SR22470. 
SRNL-STI-2012-00193

Revision 0

\section{DISCLAIMER}

This work was prepared under an agreement with and funded by the U.S. Government. Neither the U.S. Government or its employees, nor any of its contractors, subcontractors or their employees, makes any express or implied:

1. warranty or assumes any legal liability for the accuracy, completeness, or for the use or results of such use of any information, product, or process disclosed; or

2. representation that such use or results of such use would not infringe privately owned rights; or

3. endorsement or recommendation of any specifically identified commercial product, process, or service.

Any views and opinions of authors expressed in this work do not necessarily state or reflect those of the United States Government, or its contractors, or subcontractors.

\section{Printed in the United States of America \\ Prepared for \\ U.S. Department of Energy}


Keywords: MST, mMST, engineered titanates, strontium, actinides

Retention: Permanent

\title{
Testing and Characterization of Engineered Forms of Monosodium Titanate (MST)
}

\author{
K. M. L. Taylor-Pashow \\ C. A. Nash \\ D. T. Hobbs
}

May 2012

Savannah River National Laboratory Savannah River Nuclear Solutions, LLC Aiken, SC 29808

Prepared for the U.S. Department of Energy under contract number DE-AC09-08SR22470. 


\section{REVIEWS AND APPROVALS}

AUTHORS:

K. M. L. Taylor-Pashow, Separations and Actinide Science Programs

Date

C. A. Nash, Advanced Characterization and Processing

Date

D. T. Hobbs, Separations and Actinide Science Programs

Date

TECHNICAL REVIEW:

F. F. Fondeur, Separations and Actinide Science Programs

Date

APPROVAL:

S. D. Fink, Manager

Date

Separations and Actinide Science Programs

S.L. Marra, Manager

Date

Environmental \& Chemical Process Technology Research Programs 


\section{EXECUTIVE SUMMARY}

Engineered forms of MST and mMST were prepared at ORNL using an internal gelation process. Samples of these two materials were characterized at SRNL to examine particle size and morphology, peroxide content, tapped densities, and $\mathrm{Na}$, $\mathrm{Ti}$, and $\mathrm{C}$ content. Batch contact tests were also performed to examine the performance of the materials. The ${ }^{\mathrm{E}} \mathrm{mMST}$ material was found to contain less than $10 \%$ of the peroxide found in a freshly prepared batch of mMST. This was also evidenced in batch contact testing with both simulated and actual waste, where little difference in performance was seen between the two engineered materials, ${ }^{\mathrm{E}} \mathrm{MST}$ and ${ }^{\mathrm{E}} \mathrm{mMST}$.

Based on these results, attempts were made to increase the peroxide content of the materials by post-treatment with hydrogen peroxide. The peroxide treatment resulted in a slight $(\sim 10 \%)$ increase in peroxide content; however, the peroxide:Ti molar ratio was still much lower $(\sim 0.1 \mathrm{X})$ than what is seen in a freshly prepared batch of mMST. Testing with simulated waste showed the performance of the peroxide treated materials was improved.

Batch contact tests were also performed with an earlier (2003) prepared lot of ${ }^{\mathrm{E}} \mathrm{MST}$ to examine the effect of ionic strength on the performance of the material. In general the results showed a decrease in removal performance with increasing ionic strength, which is consistent with previous testing with MST. A Sr loading isotherm was also determined, and the ${ }^{\mathrm{E}} \mathrm{MST}$ material was found to reach a Sr loading as high as $13.2 \mathrm{wt} \%$ after 100 days of contact at a phase ratio of 20000 $\mathrm{mL} / \mathrm{g}$. At the typical MST phase ratio of $2500 \mathrm{~mL} / \mathrm{g}(0.4 \mathrm{~g} / \mathrm{L})$, a Sr loading of $2.64 \mathrm{wt} \%$ was reached after 506 hours of contact.

Samples of ${ }^{\mathrm{E}} \mathrm{MST}$ and the post-peroxide treated ${ }^{\mathrm{E}} \mathrm{mMST}$ were also tested in a column configuration using simulated waste solution. The breakthrough curves along with analysis of the sorbent beds at the conclusion of the experiments showed that the peroxide treated ${ }^{\mathrm{E}} \mathrm{mMST}$ has a higher $\mathrm{Sr}$ and $\mathrm{Np}$ capacity, but that both materials have similar $\mathrm{Pu}$ capacities. The ${ }^{\mathrm{E}} \mathrm{MST}$ removed a larger percentage of $U$ than the peroxide treated ${ }^{\mathrm{E}} \mathrm{mMST}$, which is consistent with previous testing which showed that mMST has little affinity for U under these conditions. 


\section{TABLE OF CONTENTS}

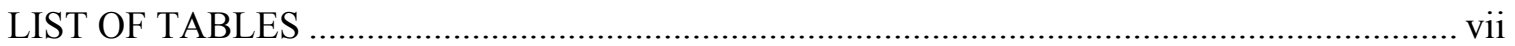

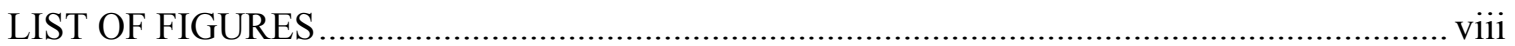

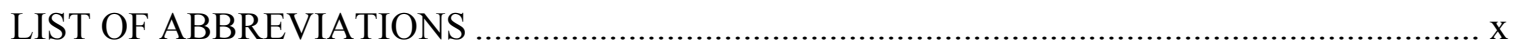

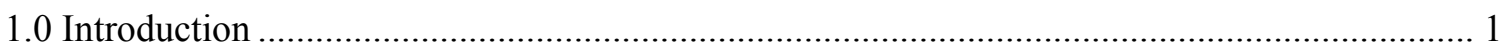

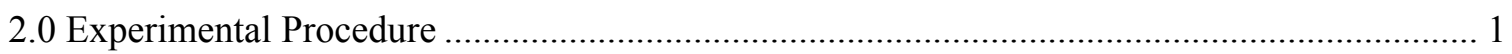

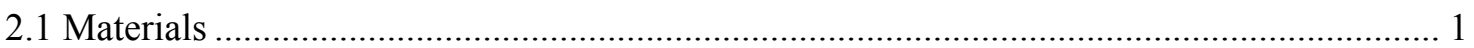

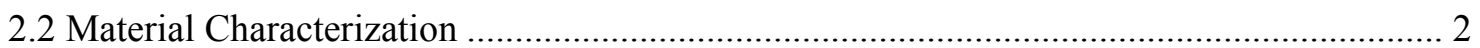

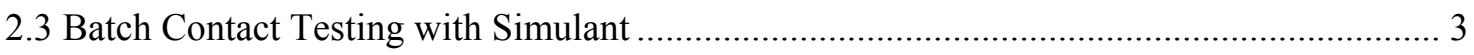

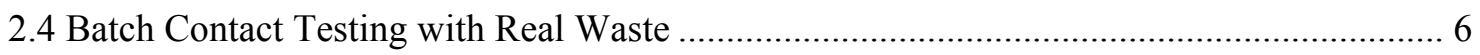

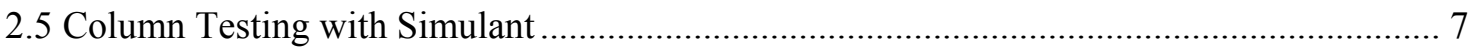

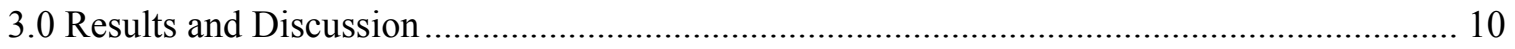

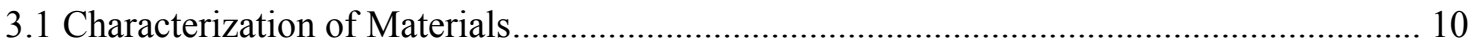

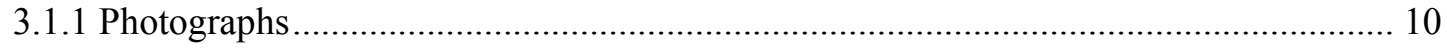

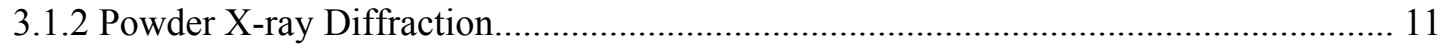

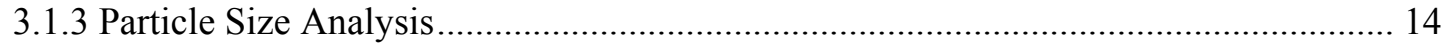

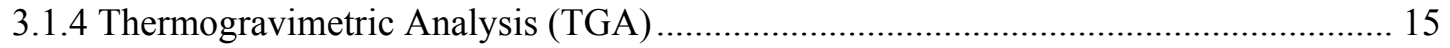

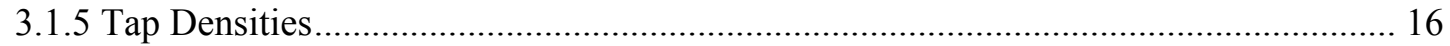

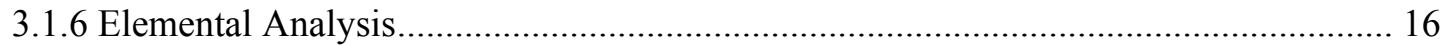

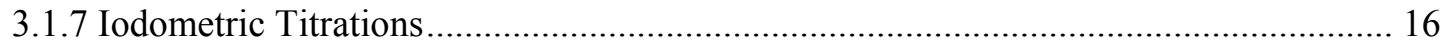

3.2 Batch Contact Testing - Effect of Ionic Strength ............................................................ 17

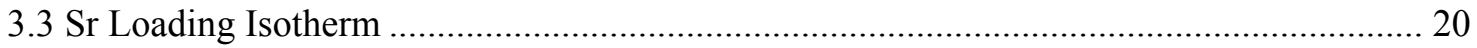

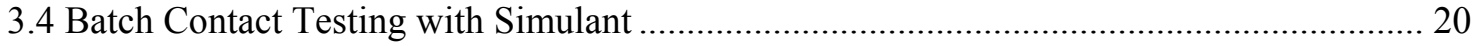

${ }^{*}$ Results indicated an error in sampling, these results should be disregarded............................ 23

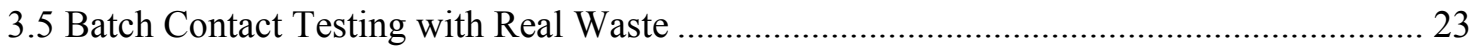

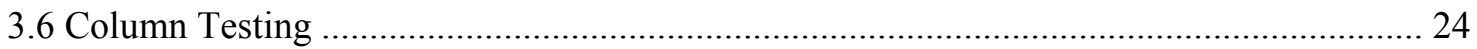

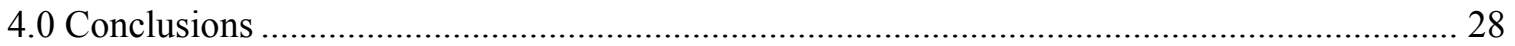

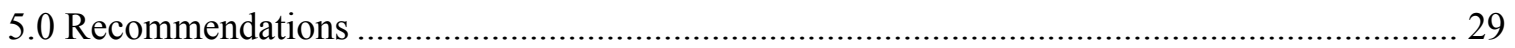

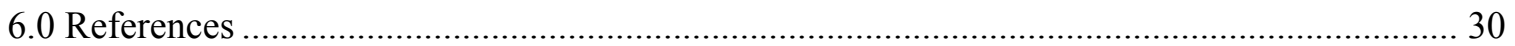




\section{LIST OF TABLES}

Table 2-1. Composition of Simulants Used in Tests ET 1-14 (Varying Ionic Strength). ............. 4

Table 2-2. Composition of Simulant Used for Sr Loading Isotherm Testing (ET 15-21)............. 5

Table 2-3. Composition of Simulant Used for Tests ET 24-37 (SWS-5-2009). .......................... 5

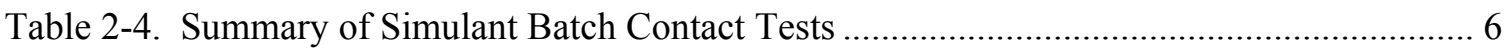

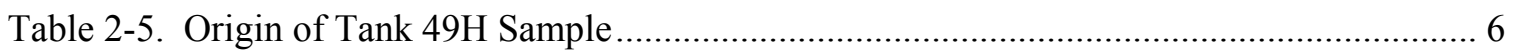

Table 2-6. Composition of the Tank 49H Sample..................................................................... 7

Table 2-7. Composition of Simulant Used for Column Testing................................................... 8

Table 2-8. Composition of Salt Solution Used for Pre-Soaking Materials for Column (SWS-1-

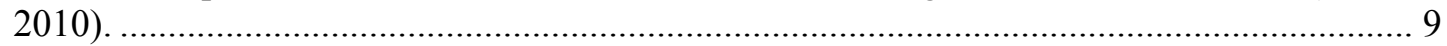

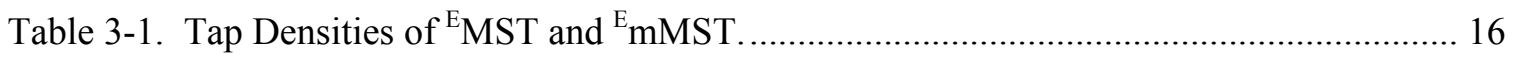

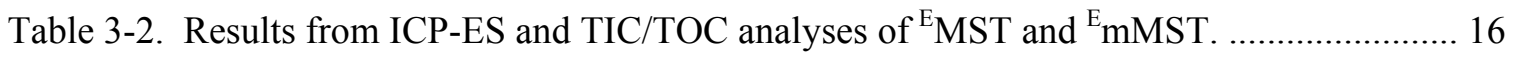

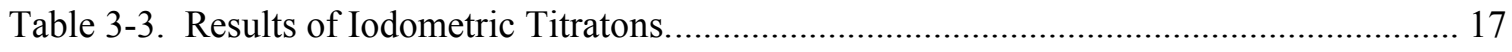

Table 3-4. Summary of DFs for Batch Contact Testing with Simulant. ..................................... 22

Table 3-5. Comparison of DFs for ${ }^{\mathrm{E}} \mathrm{MST}$ and ${ }^{\mathrm{E}} \mathrm{mMST}$ before and after peroxide treatment....... 23

Table 3-6. Summary of DF values from real waste testing. (Number in parentheses represents 1

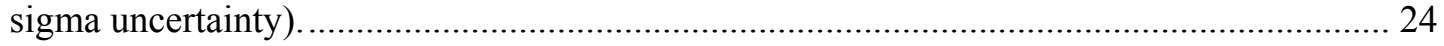

Table 3-7. Sorbate loadings on ${ }^{\mathrm{E}} \mathrm{MST}$ and peroxide treated ${ }^{\mathrm{E}} \mathrm{mMST}$ at the end of the column runs. The values in parenthesis indicate the percentage of the feed that was sorbed...................... 28

Table A-1. Summary of DFs obtained in varying ionic strength simulants. ........................... A-2

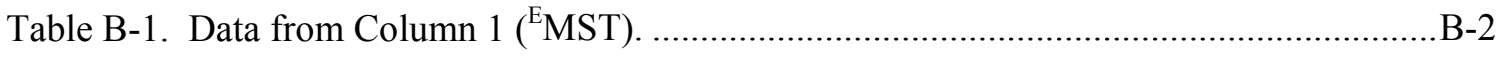

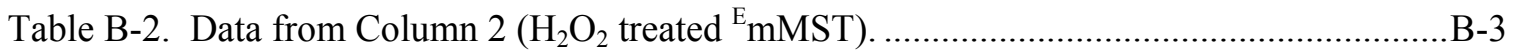




\section{LIST OF FIGURES}

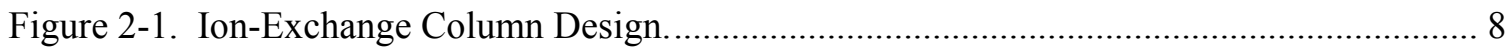

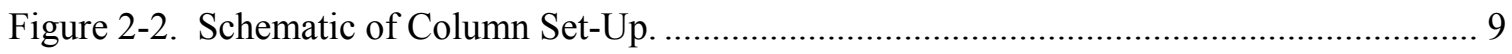

Figure 3-1. Photos of 2010 ORNL prepared ${ }^{\mathrm{E}} \mathrm{MST}$ at 10x (left) and 55x (right) magnification.. 10

Figure 3-2. Photos of 2010 ORNL prepared ${ }^{\mathrm{E}} \mathrm{mMST}$ at 10x (left) and 55x (right) magnification. 10

Figure 3-3. Photos of peroxide treated ${ }^{\mathrm{E}} \mathrm{MST}$ at 16x (left) and 63x (right) magnification.......... 11

Figure 3-4. Photos of peroxide treated ${ }^{\mathrm{E}} \mathrm{mMST}$ at 16x (left) and 63x (right) magnifications...... 11

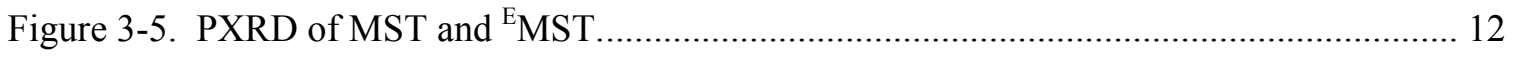

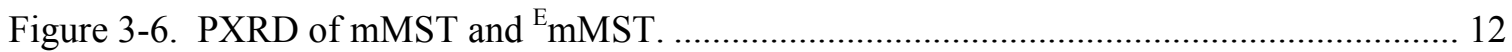

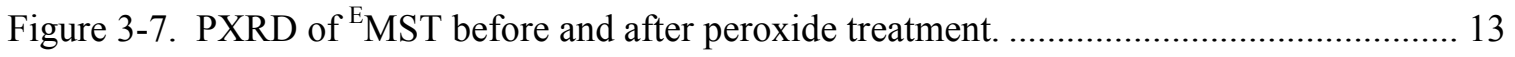

Figure 3-8. PXRD of ${ }^{\mathrm{E}} \mathrm{mMST}$ before and after peroxide treatment. ......................................... 13

Figure 3-9. Number based particle size distribution of ${ }^{\mathrm{E}} \mathrm{MST},{ }^{\mathrm{E}} \mathrm{mMST}$, and the peroxide treated

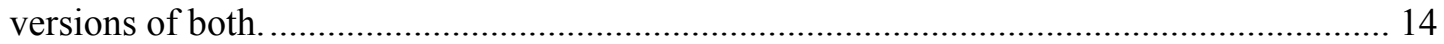

Figure 3-10. Volume based particle size distribution of ${ }^{\mathrm{E}} \mathrm{MST}$, ${ }^{\mathrm{E}} \mathrm{mMST}$, and the peroxide treated versions of both. 15

Figure 3-11. TGA of 2010 ORNL Prepared Samples of ${ }^{\mathrm{E}} \mathrm{MST}$ and ${ }^{\mathrm{E}} \mathrm{mMST}$.............................. 15

Figure 3-12. ${ }^{85} \mathrm{Sr}$ DF values versus Na concentration of the simulant for ${ }^{\mathrm{E}} \mathrm{MST}$ and MST........ 18

Figure 3-13. Pu DF values versus Na concentration of the simulant for ${ }^{\mathrm{E}} \mathrm{MST}$ and MST.......... 18

Figure 3-14. Np DF values versus Na concentration of the simulant for ${ }^{\mathrm{E}} \mathrm{MST}$ and MST. ......... 19

Figure 3-15. U DF values versus Na concentration of the simulant for ${ }^{\mathrm{E}} \mathrm{MST}$ and MST. ........... 19

Figure 3-16. Sr loading isotherms for ${ }^{\mathrm{E}} \mathrm{MST}$ (per g of MST basis) at various liquid:solid phase

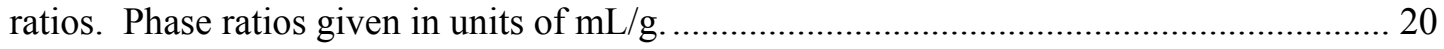

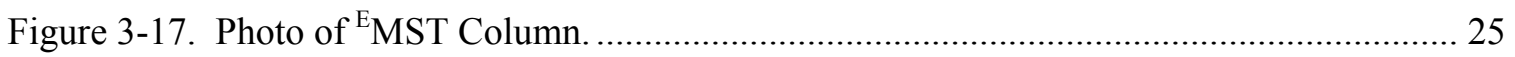

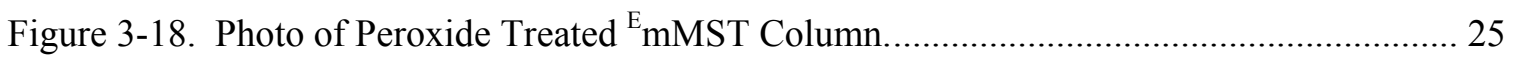

Figure 3-19. ${ }^{85} \mathrm{Sr}$ breakthrough curves for the ${ }^{\mathrm{E}} \mathrm{MST}$ and peroxide treated ${ }^{\mathrm{E}} \mathrm{mMST}$ columns. .... 26

Figure 3-20. Pu breakthrough curves for the ${ }^{\mathrm{E}} \mathrm{MST}$ and peroxide treated ${ }^{\mathrm{E}} \mathrm{mMST}$ columns...... 27

Figure 3-21. Np breakthrough curves for the ${ }^{\mathrm{E}} \mathrm{MST}$ and peroxide treated ${ }^{\mathrm{E}} \mathrm{mMST}$ columns....... 27

Figure 3-22. U breakthrough curves for the ${ }^{\mathrm{E}} \mathrm{MST}$ and peroxide treated ${ }^{\mathrm{E}} \mathrm{mMST}$ columns........ 28

Figure A-1. ${ }^{85} \mathrm{Sr}$ activity versus contact time for Tests ET-24 through ET-33 ......................... A-3 
Figure A-2. ${ }^{85} \mathrm{Sr}$ DF versus contact time for Tests ET-25 through ET-33 ............................... A-3

Figure A-3. Pu concentration versus contact time for Tests ET-24 through ET-33.................. A-4

Figure A-4. Pu DF versus contact time for Tests ET-25 through ET-33. ............................... A-4

Figure A-5. ${ }^{237} \mathrm{~Np}$ concentration versus contact time for Tests ET-24 through ET-33 ............. A-5

Figure A-6. ${ }^{237} \mathrm{~Np}$ DF versus contact time for Tests ET-25 through ET-33 ............................ A-5

Figure A-7. U concentration versus contact time for Tests ET-24 through ET-33 .................. A-6

Figure A-8. U DF versus contact time for Tests ET-25 through ET-33 .................................. A-6

Figure A-9.u ${ }^{90} \mathrm{Sr}$ activity versus contact time for real waste tests....................................... A-7

Figure A-10. ${ }^{90} \mathrm{Sr}$ DF versus contact time for real waste tests................................................ A-7

Figure A-11. Pu concentration versus contact time for real waste tests................................. A-8

Figure A-12. Pu DF versus contact time for real waste tests. ........................................... A-8

Figure A-13. ${ }^{237} \mathrm{~Np}$ concentration versus contact time for real waste tests. ............................. A-9

Figure A-14. ${ }^{237} \mathrm{~Np}$ DF versus contact time for real waste tests. ........................................... A-9

Figure A-15. U concentration versus contact time for real waste tests. ................................ A-10

Figure A-16. U DF versus contact time for real waste tests.................................................. A-10 


\section{LIST OF ABBREVIATIONS}

$\begin{array}{ll}\text { ARP } & \text { Actinide Removal Process } \\ \text { CST } & \text { crystalline silicotitanate } \\ \text { DF } & \text { decontamination factor } \\ \text { DWPF } & \text { Defense Waste Processing Facility } \\ { }^{\text {E}} \text { MST } & \text { engineered monosodium titanate } \\ { }^{\text {EmMST }} & \text { engineered modified monosodium titanate } \\ \text { ICP-ES } & \text { inductively coupled plasma - emission spectroscopy } \\ \text { ICP-MS } & \text { inductively coupled plasma - mass spectroscopy } \\ \text { MST } & \text { monosodium titanate } \\ \text { mMST } & \text { modified monosodium titanate } \\ \text { ORNL } & \text { Oak Ridge National Laboratory } \\ \text { PuTTA } & \text { plutonium thenoyltrifluoroacetone scintillation } \\ \text { PVDF } & \text { polyvinylidene fluoride } \\ \text { PXRD } & \text { powder X-ray diffraction } \\ \text { SCIX } & \text { small column ion exchange } \\ \text { SRNL } & \text { Savannah River National Laboratory } \\ \text { SRS } & \text { Savannah River Site } \\ \text { SWPF } & \text { Salt Waste Processing Facility } \\ \text { TGA } & \text { Thermogravimetric Analysis } \\ \text { TIC/TOC } & \text { total organic carbon/total inorganic carbon } \\ \text { WTP } & \text { Waste Treatment and Immobilization Plant }\end{array}$




\subsection{Introduction}

The Department of Energy - Office of Environmental Management is funding development of At Tank or Near Tank HLW treatment processes for use at the Hanford Site and the Savannah River Site (SRS). The primary objective is to accelerate waste processing by maximizing the available compliant tank space to efficiently support permanent waste disposal including vitrification and to treat problematic waste prior to transfer to the either the Waste Treatment and Immobilization Plant (WTP) or Salt Waste Processing Facility (SWPF). This technology will also assist in the alignment of the salt and sludge processing life cycle at SRS, thereby eliminating the 7-year salt only campaign at the Defense Waste Processing Facility (DWPF).

Transformational acceleration of waste pretreatment will be realized by combining all radiochemical separations into a single unit operation within waste tanks. Combined radiochemical separations can be achieved using a combined ion-exchange and sorption process within a waste tank. The ion-exchange portion of this concept is currently being developed for cesium removal and is referred to as small column ion exchange (SCIX). However, the SCIX process as currently planned uses the ion-exchanger crystalline silicotitanate (CST). This material is very effective for removal of cesium and, to a lesser degree, strontium. However, this material has no affinity for the actinide elements and, thus, an additional treatment step would be needed to remove the alpha activity in the waste. The purpose of this work is to develop a sorption material for deployment in a column configuration in combination with an ion-exchange material.

The proposed process would add an engineered form of monosodium titanate ( $\left.{ }^{\mathrm{E}} \mathrm{MST}\right)$ or peroxide-modified monosodium titanate ( ${ }^{\mathrm{E}} \mathrm{mMST}$ ) that could be deployed in a SCIX column. The ${ }^{\mathrm{E}}$ MST and ${ }^{\mathrm{E}} \mathrm{mMST}$ could be utilized in a separate column or mixed with CST to provide a mixed ion-exchange bed in the SCIX column. Earlier work identified an internal gelation process as an efficient method for producing an engineered form of MST. ${ }^{1}$ In the current work, limited quantities of engineered forms of both MST and mMST ( ${ }^{\mathrm{E}} \mathrm{MST}$ and ${ }^{\mathrm{E}} \mathrm{mMST}$ ) were produced using the internal gelation process. These materials have been extensively characterized, and their $\mathrm{Sr}$ and actinide removal performance has been tested through batch contact testing with both simulated and actual waste, and also in a small column using a simulated waste solution.

\subsection{Experimental Procedure}

\subsection{Materials}

The baseline MST used in these studies was prepared using a sol-gel process developed at the Savannah River National Laboratory (SRNL) and supplied by Optima Chemical Group LLC (Douglas, GA, Lot \#00-QAB-417) as a 15 wt \% suspension in water containing 0.10-0.15 M $\mathrm{NaOH}$ and $100-150 \mathrm{mg} \mathrm{L}{ }^{-1} \mathrm{NaNO}_{2}{ }^{2}$ Modified monosodium titanate (mMST) used in these studies was prepared by the post-synthesis treatment of MST with hydrogen peroxide. The details of this procedure have been previously published. ${ }^{3}$ A quantity of the mMST (LS-10) was prepared using 25 grams of the Optima-supplied MST.

The engineered forms of MST and mMST ( ${ }^{\mathrm{E}} \mathrm{MST}$ and $\left.{ }^{\mathrm{E}} \mathrm{mMST}\right)$ were prepared by researchers at Oak Ridge National Laboratory (ORNL) using an internal gelation process to incorporate the MST or mMST into a hydrous titanium oxide matrix. ${ }^{1}$ The first samples of ${ }^{\mathrm{E}} \mathrm{MST}$ were prepared by ORNL in 2003. These materials were prepared by incorporating either $32 \mathrm{wt} \%$ or $50 \mathrm{wt} \%$ MST. The MST used for this material was from Optima, Lot \# 00-QAB-417. Additional samples of both ${ }^{\mathrm{E}}$ MST and ${ }^{\mathrm{E}} \mathrm{mMST}$ were prepared by ORNL in 2010 using the same method. 
These samples incorporated $45 \mathrm{wt} \%$ of the MST or mMST. For the 2010 material, SRNL provided ORNL with MST from Harrell Industries, along with a laboratory prepared sample of mMST. The mMST was prepared by treatment of the same Harrell MST with $\mathrm{H}_{2} \mathrm{O}_{2}$ following the previously published procedure. ${ }^{3}$

Samples of the $2010{ }^{\mathrm{E}}$ MST and ${ }^{\mathrm{E}} \mathrm{mMST}$ were also post-treated with $\mathrm{H}_{2} \mathrm{O}_{2}$, in an attempt to improve the performance of the materials. For this process, a similar procedure to that used to prepare mMST from MST was used. Samples of ${ }^{\mathrm{E}} \mathrm{MST}$ and ${ }^{\mathrm{E}} \mathrm{mMST}$ were suspended in water, and the $\mathrm{pH}$ of the suspensions was adjusted to 7 . Hydrogen peroxide $(30 \mathrm{wt} \%)$ was then added dropwise, while mixing. The amount of $\mathrm{H}_{2} \mathrm{O}_{2}$ added was the amount needed to provide a $3: 1$ $\mathrm{H}_{2} \mathrm{O}_{2}$ :Ti mole ratio. The moles of Ti was based on the total Ti content of the material, including $\mathrm{Ti}$ from the binder. After the addition was complete, the reactions were mixed at $25{ }^{\circ} \mathrm{C}$ for 24 hours. The products were then isolated and washed 6 times with distilled water. After the washing was complete, the products were suspended in water, and the $\mathrm{pH}$ of the suspension was adjusted to 4 . The products were then collected by filtration, washed again with distilled water, and then dried in a vacuum oven at $50{ }^{\circ} \mathrm{C}$. The peroxide treatment resulted in the formation of some fines; however, these were removed during the washing sequence.

\subsection{Material Characterization}

Samples of the ${ }^{\mathrm{E}} \mathrm{MST}$ and ${ }^{\mathrm{E}} \mathrm{mMST}$, along with the peroxide treated versions, were characterized using a number of methods. Samples of each material were submitted for powder X-ray diffraction (PXRD), particle size analysis, and total organic carbon/total inorganic carbon (TIC/TOC) analysis. Thermogravimetric analysis (TGA) was also performed for 2010 ORNL prepared materials. Photos of the materials were obtained using an optical microscope (Leica MZ Apo).

Samples of the ${ }^{\mathrm{E}} \mathrm{MST}$ and ${ }^{\mathrm{E}} \mathrm{mMST}$ were digested and submitted for inductively coupled plasma emission spectroscopy (ICP-ES). For the digestion, samples of approximately $50 \mathrm{mg}$ were placed in a small glass beaker. Distilled water $(2 \mathrm{~mL})$ and concentrated sulfuric acid $(2 \mathrm{~mL})$ were then added to the particles. The mixture was then heated on a hot-plate, with stirring, until the solids had dissolved. Once dissolved, the solution was transferred to a $50-\mathrm{mL}$ volumetric flask, and diluted to volume with distilled water. Samples of this solution were then submitted for ICP-ES analysis.

The tap densities of the ${ }^{\mathrm{E}} \mathrm{MST}$ and ${ }^{\mathrm{E}} \mathrm{mMST}$ were also determined. For these measurements, a $10-\mathrm{mL}$ graduated cylinder was loosely filled to the $10-\mathrm{mL}$ mark with either ${ }^{\mathrm{E}} \mathrm{MST}$ or ${ }^{\mathrm{E}} \mathrm{mMST}$. The mass was then determined. The graduated cylinder was then gently tapped until the volume of the beads was no longer changing. This volume was then recorded. The tap density was then determined by dividing the mass by the final tapped volume, giving the density in $\mathrm{g} / \mathrm{mL}$. The measurements were performed in triplicate.

The peroxide contents of the materials were also measured using an iodometric titration method. The general procedure for the titrations involved first performing the reaction between sodium iodide and peroxide to form iodine, which was then titrated with sodium thiosulfate using starch as an indicator. See reactions 1 and 2 below.

$$
\begin{array}{r}
\mathrm{H}_{2} \mathrm{O}_{2}+2 \mathrm{I}^{-}+2 \mathrm{H}^{+} \rightarrow \mathrm{I}_{2}+2 \mathrm{H}_{2} \mathrm{O} \\
2 \mathrm{Na}_{2} \mathrm{~S}_{2} \mathrm{O}_{3}+\mathrm{I}_{2} \rightarrow \mathrm{Na}_{2} \mathrm{~S}_{4} \mathrm{O}_{6}+2 \mathrm{NaI}
\end{array}
$$


Samples of the engineered materials were first ground using a mortar and pestle to reduce the particle size of the material. Samples of each material $(\sim 0.77-0.80 \mathrm{~g})$ were then placed in $25-\mathrm{mL}$ volumetric flasks. The particles were suspended in approximately $15-20 \mathrm{~mL}$ of distilled water. Next, $0.42 \mathrm{~mL}$ aliquots of $18 \mathrm{M}$ sulfuric acid were added to the suspensions, and the samples were then diluted to the $25-\mathrm{mL}$ mark with additional distilled water. The suspensions were then transferred to glass vessels containing stir bars, and $20 \mathrm{~mL}$ aliquots of a $0.27 \mathrm{M}$ solution of sodium iodide were added. These reactions were then stirred at room temperature for $\sim 24$ hours. Aliquots of the reaction mixture were then removed and titrated with a $0.1 \mathrm{M}$ solution of sodium thiosulfate, using starch as an indicator. All titrations were performed in triplicate.

\subsection{Batch Contact Testing with Simulant}

A series of batch contact tests were performed with simulated waste solutions to examine the uptake of $\mathrm{Sr}$ and actinides by the engineered materials. Testing of the materials included both the 2003 prepared ORNL sample of ${ }^{\mathrm{E}} \mathrm{MST}$ with a $50 \mathrm{wt} \%$ MST loading, and the 2010 prepared ORNL samples of ${ }^{\mathrm{E}} \mathrm{MST}$ and ${ }^{\mathrm{E}} \mathrm{mMST}$ with $45 \mathrm{wt} \%$ loadings of MST and mMST. The first set of tests performed (ET 1-14) examine the performance of the $2003{ }^{\mathrm{E}} \mathrm{MST}$ in simulants with varying ionic strength. The target sodium concentrations of the simulants ranged from $5.6 \mathrm{M}$ to $8.0 \mathrm{M}$. The composition of the simulants is provided in Table 2-1. A sample of the Optima MST (00QAB-417) was also tested at the lowest and highest ionic strengths for comparison. The sorption tests were performed as follows. Fifty milliliters of the appropriate simulant was placed into each of $14125-\mathrm{mL}$ polyethylene bottles. ${ }^{\mathrm{E}} \mathrm{MST}$ or MST was then added to the appropriate test bottles, at an MST concentration of $0.4 \mathrm{~g} / \mathrm{L}$. The amount of ${ }^{\mathrm{E}} \mathrm{MST}$ added was based on the $50 \mathrm{wt} \%$ reported loading of MST. The bottles were then placed in a temperature controlled waterbath shaker, and were mixed at $25{ }^{\circ} \mathrm{C}$. Samples were removed after 6, 30, 120, and 191 hours. At each sampling event, the bottle was removed from the waterbath and manually shaken for 30 seconds to ensure the solids were homogeneously suspended. A sample was then removed and filtered through a $0.1-\mu \mathrm{m}$ polyvinylidene fluoride (PVDF) syringe filter to remove the solids. An aliquot of the filtrate $(3 \mathrm{~mL})$ was acidified with $5 \mathrm{M}$ nitric acid $(6 \mathrm{~mL})$ and submitted for inductively coupled plasma - mass spectroscopy (ICP-MS), gamma scan, and plutonium thenoyltrifluoroacetone scintillation (PuTTA) analyses. 
Table 2-1. Composition of Simulants Used in Tests ET 1-14 (Varying Ionic Strength).

\begin{tabular}{|c|c|c|c|c|c|c|}
\hline \multirow{2}{*}{ Component } & \multicolumn{2}{|c|}{ SWS-7-2010-1 } & \multicolumn{2}{|c|}{ SWS-7-2010-2 } & \multicolumn{2}{|c|}{ SWS-7-2010-3 } \\
\hline & Target & Measured & Target & Measured & Target & Measured \\
\hline $\mathrm{NaNO}_{3}$ & $2.03 \mathrm{M}$ & $1.98 \mathrm{M}$ & $2.18 \mathrm{M}$ & $2.05 \mathrm{M}$ & $2.36 \mathrm{M}$ & $1.94 \mathrm{M}$ \\
\hline $\mathrm{NaOH}$ & $2.21 \mathrm{M}$ & $2.01 \mathrm{M}$ & $2.37 \mathrm{M}$ & $2.20 \mathrm{M}$ & $2.57 \mathrm{M}$ & $1.88 \mathrm{M}$ \\
\hline $\mathrm{Na}_{2} \mathrm{SO}_{4}$ & $0.140 \mathrm{M}$ & $0.127 \mathrm{M}$ & $0.150 \mathrm{M}$ & $0.134 \mathrm{M}$ & $0.163 \mathrm{M}$ & $0.125 \mathrm{M}$ \\
\hline $\mathrm{NaAl}(\mathrm{OH})_{4}$ & $0.280 \mathrm{M}$ & $0.278 \mathrm{M}$ & $0.300 \mathrm{M}$ & $0.289 \mathrm{M}$ & $0.325 \mathrm{M}$ & $0.303 \mathrm{M}$ \\
\hline $\mathrm{NaNO}_{2}$ & $0.500 \mathrm{M}$ & $0.496 \mathrm{M}$ & $0.536 \mathrm{M}$ & $0.513 \mathrm{M}$ & $0.580 \mathrm{M}$ & $0.489 \mathrm{M}$ \\
\hline $\mathrm{Na}_{2} \mathrm{CO}_{3}$ & $0.150 \mathrm{M}$ & $0.160 \mathrm{M}$ & $0.161 \mathrm{M}$ & $0.162 \mathrm{M}$ & $0.174 \mathrm{M}$ & $0.184 \mathrm{M}$ \\
\hline Total Na & $5.6 \mathrm{M}$ & $5.39 \mathrm{M}$ & $6.00 \mathrm{M}$ & $5.65 \mathrm{M}$ & $6.50 \mathrm{M}$ & $5.79 \mathrm{M}$ \\
\hline $\mathbf{K}^{+}$ & $0.007 \mathrm{M}$ & NM & $0.007 \mathrm{M}$ & NM & $0.007 \mathrm{M}$ & NM \\
\hline Total Sr & $2.0 \mathrm{mg} / \mathrm{L}$ & $1.68 \mathrm{mg} / \mathrm{L}$ & $2.0 \mathrm{mg} / \mathrm{L}$ & $2.67 \mathrm{mg} / \mathrm{L}$ & $2.0 \mathrm{mg} / \mathrm{L}$ & $2.21 \mathrm{mg} / \mathrm{L}$ \\
\hline${ }^{85} \mathrm{Sr}$ & $\begin{array}{c}30,000 \\
\mathrm{dpm} / \mathrm{mL}\end{array}$ & $\begin{array}{c}2.77 \mathrm{E}+04 \\
\mathrm{dpm} / \mathrm{mL}\end{array}$ & $\begin{array}{c}30,000 \\
\mathrm{dpm} / \mathrm{mL}\end{array}$ & $\begin{array}{l}1.99 \mathrm{E}+04 \\
\mathrm{dpm} / \mathrm{mL}\end{array}$ & $\begin{array}{c}30,000 \\
\mathrm{dpm} / \mathrm{mL}\end{array}$ & $\begin{array}{c}3.56 \mathrm{E}+04 \\
\mathrm{dpm} / \mathrm{mL}\end{array}$ \\
\hline Total Pu & $200 \mu \mathrm{g} / \mathrm{L}$ & $114 \mu \mathrm{g} / \mathrm{L}$ & $200 \mu \mathrm{g} / \mathrm{L}$ & $143 \mu \mathrm{g} / \mathrm{L}$ & $200 \mu \mathrm{g} / \mathrm{L}$ & $167 \mu \mathrm{g} / \mathrm{L}$ \\
\hline${ }^{237} \mathrm{~Np}$ & $500 \mu \mathrm{g} / \mathrm{L}$ & $457 \mu \mathrm{g} / \mathrm{L}$ & $500 \mu \mathrm{g} / \mathrm{L}$ & $402 \mu \mathrm{g} / \mathrm{L}$ & $500 \mu \mathrm{g} / \mathrm{L}$ & $497 \mu \mathrm{g} / \mathrm{L}$ \\
\hline Total U & $10,000 \mu \mathrm{g} / \mathrm{L}$ & $9,260 \mu \mathrm{g} / \mathrm{L}$ & $10,000 \mu \mathrm{g} / \mathrm{L}$ & $9,600 \mu \mathrm{g} / \mathrm{L}$ & $10,000 \mu \mathrm{g} / \mathrm{L}$ & $9,290 \mu \mathrm{g} / \mathrm{L}$ \\
\hline${ }^{137} \mathrm{Cs}$ & $\begin{array}{c}30,000 \\
\mathrm{dpm} / \mathrm{mL}\end{array}$ & $\begin{array}{l}1.05 \mathrm{E}+05 \\
\mathrm{dpm} / \mathrm{mL}\end{array}$ & $\begin{array}{c}30,000 \\
\mathrm{dpm} / \mathrm{mL}\end{array}$ & $\begin{array}{c}2.14 \mathrm{E}+05 \\
\mathrm{dpm} / \mathrm{mL}\end{array}$ & $\begin{array}{c}30,000 \\
\mathrm{dpm} / \mathrm{mL}\end{array}$ & $\begin{array}{c}2.11 \mathrm{E}+05 \\
\mathrm{dpm} / \mathrm{mL}\end{array}$ \\
\hline \multirow{2}{*}{ Component } & \multicolumn{2}{|c|}{ SWS-7-2010-4 } & \multicolumn{2}{|c|}{ SWS-7-2010-5 } & \multicolumn{2}{|c|}{ SWS-7-2010-6 } \\
\hline & Target & Measured & Target & Measured & Target & Measured \\
\hline $\mathrm{NaNO}_{3}$ & $2.54 \mathrm{M}$ & $2.40 \mathrm{M}$ & $2.72 \mathrm{M}$ & $2.61 \mathrm{M}$ & $2.90 \mathrm{M}$ & $2.71 \mathrm{M}$ \\
\hline $\mathrm{NaOH}$ & $2.76 \mathrm{M}$ & $2.48 \mathrm{M}$ & $2.96 \mathrm{M}$ & $1.91 \mathrm{M}$ & $3.16 \mathrm{M}$ & $2.14 \mathrm{M}$ \\
\hline $\mathrm{Na}_{2} \mathrm{SO}_{4}$ & $0.175 \mathrm{M}$ & $0.112 \mathrm{M}$ & $0.188 \mathrm{M}$ & $0.119 \mathrm{M}$ & $0.200 \mathrm{M}$ & $0.129 \mathrm{M}$ \\
\hline $\mathrm{NaAl}(\mathrm{OH})_{4}$ & $0.350 \mathrm{M}$ & $0.311 \mathrm{M}$ & $0.375 \mathrm{M}$ & $0.388 \mathrm{M}$ & $0.400 \mathrm{M}$ & $0.358 \mathrm{M}$ \\
\hline $\mathrm{NaNO}_{2}$ & $0.625 \mathrm{M}$ & $0.522 \mathrm{M}$ & $0.670 \mathrm{M}$ & $0.565 \mathrm{M}$ & $0.714 \mathrm{M}$ & $0.604 \mathrm{M}$ \\
\hline $\mathrm{Na}_{2} \mathrm{CO}_{3}$ & $0.188 \mathrm{M}$ & $0.191 \mathrm{M}$ & $0.201 \mathrm{M}$ & $0.207 \mathrm{M}$ & $0.214 \mathrm{M}$ & $0.220 \mathrm{M}$ \\
\hline Total Na & $7.00 \mathrm{M}$ & $5.92 \mathrm{M}$ & $7.50 \mathrm{M}$ & $6.44 \mathrm{M}$ & $8.00 \mathrm{M}$ & 6.83 \\
\hline $\mathbf{K}^{+}$ & $0.007 \mathrm{M}$ & NM & $0.007 \mathrm{M}$ & NM & $0.007 \mathrm{M}$ & NM \\
\hline Total Sr & $2.0 \mathrm{mg} / \mathrm{L}$ & $1.37 \mathrm{mg} / \mathrm{L}$ & $2.0 \mathrm{mg} / \mathrm{L}$ & $2.82 \mathrm{mg} / \mathrm{L}$ & $2.0 \mathrm{mg} / \mathrm{L}$ & $2.42 \mathrm{mg} / \mathrm{L}$ \\
\hline${ }^{85} \mathrm{Sr}$ & $\begin{array}{c}30,000 \\
\mathrm{dpm} / \mathrm{mL}\end{array}$ & $\begin{array}{c}3.37 \mathrm{E}+04 \\
\mathrm{dpm} / \mathrm{mL}\end{array}$ & $\begin{array}{c}30,000 \\
\mathrm{dpm} / \mathrm{mL}\end{array}$ & $\begin{array}{c}3.15 \mathrm{E}+04 \\
\mathrm{dpm} / \mathrm{mL}\end{array}$ & $\begin{array}{c}30,000 \\
\mathrm{dpm} / \mathrm{mL}\end{array}$ & $\begin{array}{c}3.12 \mathrm{E}+04 \\
\mathrm{dpm} / \mathrm{mL}\end{array}$ \\
\hline Total Pu & $200 \mu \mathrm{g} / \mathrm{L}$ & $160 \mu \mathrm{g} / \mathrm{L}$ & $200 \mu \mathrm{g} / \mathrm{L}$ & $168 \mu \mathrm{g} / \mathrm{L}$ & $200 \mu \mathrm{g} / \mathrm{L}$ & $142 \mu \mathrm{g} / \mathrm{L}$ \\
\hline${ }^{237} \mathrm{~Np}$ & $500 \mu \mathrm{g} / \mathrm{L}$ & $482 \mu \mathrm{g} / \mathrm{L}$ & $500 \mu \mathrm{g} / \mathrm{L}$ & $475 \mu \mathrm{g} / \mathrm{L}$ & $500 \mu \mathrm{g} / \mathrm{L}$ & $487 \mu \mathrm{g} / \mathrm{L}$ \\
\hline Total U & $10,000 \mu \mathrm{g} / \mathrm{L}$ & $10,300 \mu \mathrm{g} / \mathrm{L}$ & $10,000 \mu \mathrm{g} / \mathrm{L}$ & $8,170 \mu \mathrm{g} / \mathrm{L}$ & $10,000 \mu \mathrm{g} / \mathrm{L}$ & $4,010 \mu \mathrm{g} / \mathrm{L}$ \\
\hline${ }^{137} \mathrm{Cs}$ & $\begin{array}{c}30,000 \\
\mathrm{dpm} / \mathrm{mL}\end{array}$ & $\begin{array}{c}2.10 \mathrm{E}+05 \\
\mathrm{dpm} / \mathrm{mL}\end{array}$ & $\begin{array}{r}30,000 \\
\mathrm{dpm} / \mathrm{mL}\end{array}$ & $\begin{array}{c}1.14 \mathrm{E}+05 \\
\mathrm{dpm} / \mathrm{mL}\end{array}$ & $\begin{array}{c}30,000 \\
\mathrm{dpm} / \mathrm{mL}\end{array}$ & $\begin{array}{c}1.06 \mathrm{E}+05 \\
\mathrm{dpm} / \mathrm{mL}\end{array}$ \\
\hline
\end{tabular}

The second set of tests (ET 15-21) was performed to determine the Sr loading isotherm of the ${ }^{\mathrm{E}}$ MST. For these tests, samples of the 2003 prepared ${ }^{\mathrm{E}} \mathrm{MST}$ were contacted with a non-rad simulant having a $\mathrm{Sr}$ concentration of $5.5 \mathrm{mg} / \mathrm{L}$. The composition of the simulant is provided in Table 2-2. Samples of the ${ }^{\mathrm{E}}$ MST (0.040 g each) were placed in polyethylene bottles. Aliquots of the simulant were then added to provide liquid:solid ratios of 20000 (duplicate), 5000 (duplicate), 2500 and $1250 \mathrm{~mL} / \mathrm{g}$. The test bottles were then placed in a $25^{\circ} \mathrm{C}$ shaker oven, and were shaken at a speed of $200 \mathrm{rpm}$. Samples were removed after 24, 168, 336, 504, and 2400 hours. The test bottles with liquid:solid ratios of 2500 and 1250 were only sampled once at the 504 hour time point. For each sampling event, the shaking was stopped and the bottles were left to stand undisturbed for 1 hour. A sample of the supernate was then removed and filtered through a 0.1- $\mu \mathrm{m}$ PVDF syringe filter and submitted for $\mathrm{Sr}$ analysis. 
Table 2-2. Composition of Simulant Used for Sr Loading Isotherm Testing (ET 15-21).

\begin{tabular}{|c|c|c|}
\hline \multirow{2}{*}{ Component } & \multicolumn{2}{|c|}{ SWS-10-2010 } \\
\cline { 2 - 3 } & Target & Measured \\
\hline Free NaOH & $1.33 \mathrm{M}$ & $1.11 \mathrm{M}$ \\
\hline $\mathbf{N a N O}_{3}$ & $2.60 \mathrm{M}$ & $2.54 \mathrm{M}$ \\
\hline $\mathbf{N a A l}_{\mathbf{3}}(\mathbf{O H})_{4}$ & $0.429 \mathrm{M}$ & $0.413 \mathrm{M}$ \\
\hline $\mathrm{NaNO}_{2}$ & $0.134 \mathrm{M}$ & $0.134 \mathrm{M}$ \\
\hline $\mathbf{N a}_{2} \mathrm{SO}_{4}$ & $0.521 \mathrm{M}$ & $0.496 \mathrm{M}$ \\
\hline $\mathbf{N a}_{\mathbf{2}} \mathbf{C O}_{3}$ & $0.026 \mathrm{M}$ & $0.042 \mathrm{M}$ \\
\hline Total Na & $5.6 \mathrm{M}$ & $5.68 \mathrm{M}$ \\
\hline Total Sr & $5.5 \mathrm{mg} / \mathrm{L}$ & $5.64 \mathrm{mg} / \mathrm{L}$ \\
\hline
\end{tabular}

The third set of tests (ET 24-28) examined the performance of the 2010 ORNL prepared materials, both ${ }^{\mathrm{E}} \mathrm{MST}$ and ${ }^{\mathrm{E}} \mathrm{mMST}$. The performance of these materials was compared to samples of nonengineered MST and mMST. The composition of the simulant used in this testing is provided in Table 2-3. For these tests, samples of sorbent were placed in $50-\mathrm{mL}$ centrifuge tubes. The amounts added corresponded to $0.4 \mathrm{~g} / \mathrm{L}$. The amounts of ${ }^{\mathrm{E}} \mathrm{MST}$ and ${ }^{\mathrm{E}} \mathrm{mMST}$ added were based on the $45 \mathrm{wt} \%$ reported loading of MST or mMST. Forty mL of SWS-5-2009 was then added to each tube, and the tubes were rotated at a speed of $8 \mathrm{rpm}$ on a LabQuake tumbler at ambient laboratory temperature. The tests were sampled after 1, 4, and 24 hours of mixing. At each sampling event, the tube was removed from the tumbler and manually shaken for 10-15 seconds to ensure the solids were homogeneously suspended. A sample was then removed and filtered through a $0.1-\mu \mathrm{m}$ PVDF syringe filter to remove the solids. An aliquot of the filtrate $(3 \mathrm{~mL})$ was acidified with $5 \mathrm{M}$ nitric acid $(6 \mathrm{~mL})$ and submitted for ICP-MS, gamma scan, and PuTTA analyses.

Table 2-3. Composition of Simulant Used for Tests ET 24-37 (SWS-5-2009).

\begin{tabular}{|c|c|c|}
\hline "Component & Target & Measured \\
\hline Free $\mathrm{NaOH}$ & $1.33 \mathrm{M}$ & $1.37 \mathrm{M}$ \\
\hline Total $\mathrm{NaNO}_{3}$ & $2.60 \mathrm{M}$ & $2.13 \mathrm{M}$ \\
\hline $\mathrm{NaAl}(\mathrm{OH})_{4}$ & $0.429 \mathrm{M}$ & $0.404 \mathrm{M}$ \\
\hline $\mathrm{NaNO}_{2}$ & $0.134 \mathrm{M}$ & $0.133 \mathrm{M}$ \\
\hline $\mathrm{Na}_{2} \mathrm{SO}_{4}$ & $0.521 \mathrm{M}$ & $0.483 \mathrm{M}$ \\
\hline $\mathrm{Na}_{2} \mathrm{CO}_{3}$ & $0.0260 \mathrm{M}$ & $0.0298 \mathrm{M}$ \\
\hline Total Na & $5.6 \mathrm{M}$ & $5.05 \mathrm{M}$ \\
\hline${ }^{85} \mathrm{Sr}$ & $30,000 \mathrm{dpm} / \mathrm{mL}$ & spiked before each set of tests \\
\hline Total Sr & $0.60 \mathrm{mg} / \mathrm{L}$ & $0.521 \mathrm{mg} / \mathrm{L}$ \\
\hline${ }^{137} \mathrm{Cs}$ & $30,000 \mathrm{dpm} / \mathrm{mL}$ & $96,300 \mathrm{dpm} / \mathrm{mL}$ \\
\hline Total Cs & $1.40 \times 10^{-4} \mathrm{M}$ & $1.26 \times 10^{-4} \mathrm{M}$ \\
\hline $\mathbf{P u}$ & $200 \mu \mathrm{g} / \mathrm{L}$ & $220 \mu \mathrm{g} / \mathrm{L}$ \\
\hline $\mathbf{N p}$ & $500 \mu \mathrm{g} / \mathrm{L}$ & $460 \mu \mathrm{g} / \mathrm{L}$ \\
\hline $\mathbf{U}$ & $10,000 \mu \mathrm{g} / \mathrm{L}$ & $10,700 \mu \mathrm{g} / \mathrm{L}$ \\
\hline
\end{tabular}

Tests ET 29-37 followed a similar procedure, and used the same simulant (SWS-5-2009) as tests ET 24-28. Tests ET 29-33 examined the performance of the 2010 ORNL prepared materials, ${ }^{\mathrm{E}} \mathrm{MST}$ and ${ }^{\mathrm{E}} \mathrm{mMST}$, along with the non-engineered forms of MST and mMST. For these tests MST and ${ }^{\mathrm{E}}$ MST were added at an MST concentration of $0.4 \mathrm{~g} / \mathrm{L}$, while mMST and ${ }^{\mathrm{E}} \mathrm{mMST}$ were added at an mMST concentration of $0.1 \mathrm{~g} / \mathrm{L}$. Again, the amounts of ${ }^{\mathrm{E}} \mathrm{MST}$ and ${ }^{\mathrm{E}} \mathrm{mMST}$ added were based on the $45 \mathrm{wt} \%$ reported loading of MST or mMST. These tests were sampled after 6 , 24, 48, and 168 hours of mixing, following the same sampling procedure used for Tests ET 24-28. Tests ET 34-37 examined the performance of the two post-peroxide treated samples of the 
engineered materials. The non-engineered MST was also included in this test set for comparison. In these tests, MST was added at a concentration of $0.4 \mathrm{~g} / \mathrm{L}$, while the two peroxide treated engineered materials were added at an equivalent MST concentration of $0.1 \mathrm{~g} / \mathrm{L}$. These tests were sampled after 24 and 168 hours of mixing, following the same sampling procedure used for the previous tests.

Table 2-4. Summary of Simulant Batch Contact Tests

\begin{tabular}{|c|c|c||}
\hline \hline Test Group & Purpose of Tests & Material Used \\
\hline ET 1-14 & Effect of ionic strength & 2003 prepared ${ }^{\mathrm{E}}$ MST, baseline MST \\
\hline ET 15-21 & Sr loading isotherm & 2003 prepared ${ }^{\mathrm{E}}$ MST \\
\hline ET 24-28 & $\begin{array}{c}\text { Performance of 2010 ORNL prepared }{ }^{\mathrm{E}} \text { MST and } \\
{ }^{\mathrm{E}} \text { mST }\end{array}$ & $\begin{array}{c}2010 \text { prepared }{ }^{\mathrm{E}} \text { MST and }{ }^{\mathrm{E}} \mathrm{mMST}, \\
\text { baseline MST and mMST }\end{array}$ \\
\hline ET 29-33 & $\begin{array}{c}\text { Performance of 2010 ORNL prepared }{ }^{\mathrm{E}} \text { MST and } \\
{ }^{\mathrm{E}} \text { mMST using lower concentrations of sorbent }\end{array}$ & $\begin{array}{c}2010 \text { prepared }{ }^{\mathrm{E}} \text { MST and }{ }^{\mathrm{E}} \mathrm{mMST}, \\
\text { baseline MST and mMST }\end{array}$ \\
\hline ET 34-34 & $\begin{array}{c}\text { Performance of post-peroxide treated }{ }^{\mathrm{E}} \text { MST and } \\
\mathrm{E} \text { mMST }\end{array}$ & $\begin{array}{c}\text { Peroxide treated }{ }^{\mathrm{E}} \text { MST and }{ }^{\mathrm{E}} \mathrm{mMST}, \\
\text { and baseline MST }\end{array}$ \\
\hline
\end{tabular}

\subsection{Batch Contact Testing with Real Waste}

Tests were performed using a sample of Tank $49 \mathrm{H}$ supernate. The sample of Tank $49 \mathrm{H}$ was made up of samples taken from December 2010 to February 2011. Thirteen $\sim 3$ L samples taken during this time period were combined into a $50-\mathrm{L}$ carboy, and a $400-\mathrm{mL}$ aliquot of the solution was removed and used for this testing. The details of the origin of this sample are given in Table $2-5$, and the measured composition is given in Table 2-6. The supernate was contacted with 4 different sorbents: MST, mMST, and the 2010 ORNL prepared engineered forms of MST and mMST ( ${ }^{\mathrm{E}} \mathrm{MST}$ and ${ }^{\mathrm{E}} \mathrm{mMST}$ ). The MST and ${ }^{\mathrm{E}} \mathrm{MST}$ were added at equivalent MST concentrations of $0.4 \mathrm{~g} / \mathrm{L}$, while the mMST and ${ }^{\mathrm{E}} \mathrm{mMST}$ were added at equivalent mMST concentrations of $0.2 \mathrm{~g} / \mathrm{L}$. A reduced amount of the modified versions is used due to the increased performance of the modified material compared to the baseline MST. Each test used $80 \mathrm{~mL}$ of Tank 49 supernate. The contact tests were carried out in a temperature controlled waterbath-stirrer at $25{ }^{\circ} \mathrm{C}$ for 24 hours, with stirring. Samples were removed after 2, 6, 12, and 24 hours of contact. The test bottle was shaken by hand before removing each sample. The sample was then filtered through a $0.1-\mu \mathrm{m}$ syringe filter to remove the solids. An aliquot of the filtrate was then acidified with an equal volume of $5 \mathrm{M}$ nitric acid. The samples were analyzed for ${ }^{90} \mathrm{Sr}, \mathrm{Pu}, \mathrm{Np}$, and $\mathrm{U}$ concentrations using ${ }^{90} \mathrm{Sr}$, PuTTA, and ICP-MS analyses.

Table 2-5. Origin of Tank 49H Sample

\begin{tabular}{||c|c|}
\hline Source & Tank 49H \\
\hline Date Sampled & Dec. 2010 to Feb. 2011 \\
\hline & HTF-49-10-167, -175 \\
Tank Farm Identification & HTF-49-11- $-11,-12,-15,-16,-17,-18$, \\
& Dec. 2010 to Feb. 2011 \\
\hline Date Received at SRNL & 39 \\
\hline Approximate Volume (L) &
\end{tabular}


Table 2-6. Composition of the Tank 49H Sample

\begin{tabular}{||c|c|c||}
\hline Analyte & Concentration (mg/L) & $\begin{array}{c}\text { Method \% } \\
\text { Uncertainty }\end{array}$ \\
\hline $\mathrm{Na}^{+}$ & 150,000 & 10 \\
\hline $\mathrm{K}^{+}$ & 505 & 10 \\
\hline $\mathrm{Rb}^{+}$ & 0.476 & 20 \\
\hline $\mathrm{Cs}^{+}$ & 2.09 & 20 \\
\hline $\mathrm{Free} \mathrm{OH}$ & $2.65(\mathrm{M})$ & 10 \\
\hline $\mathrm{NO}_{3}{ }^{-}$ & 188,000 & 10 \\
\hline $\mathrm{NO}_{2}{ }^{-}$ & 4160 & 10 \\
\hline $\mathrm{Al}^{3+}$ & 5110 & 10 \\
\hline $\mathrm{SO}_{4}{ }^{2-}$ & 6490 & 10 \\
\hline $\mathrm{PO}_{4}{ }^{3-}$ & 874 & 10 \\
\hline $\mathrm{CO}_{3}{ }^{2-}$ & $0.239(\mathrm{M})$ & 10 \\
\hline $\mathrm{F}^{-}$ & $<100$ & 10 \\
\hline $\mathrm{Cl}^{-}$ & 373 & 10 \\
\hline $\mathrm{Oxalate}^{-}$ & 175 & 10 \\
\hline formate & 919 & 10 \\
\hline${ }^{137} \mathrm{Cs}$ & $1.44 \mathrm{E}+08(\mathrm{dpm} / \mathrm{mL})$ & 5.00 \\
\hline${ }^{90} \mathrm{Sr}$ & $3.57 \mathrm{E}+05(\mathrm{dpm} / \mathrm{mL})$ & 9.41 \\
\hline${ }^{238} \mathrm{Pu}$ & $6.76 \mathrm{E}+04(\mathrm{dpm} / \mathrm{mL})$ & 5.64 \\
\hline${ }^{239 / 240} \mathrm{Pu}$ & $1.27 \mathrm{E}+04(\mathrm{dpm} / \mathrm{mL})$ & 5.67 \\
\hline $\mathrm{Mass}-235$ & $0.183 \mu \mathrm{g} / \mathrm{L}$ & 20 \\
\hline $\mathrm{Mass}-238$ & 26.1 & 20 \\
\hline Density & $1.269 \mathrm{~g} / \mathrm{mL}$ & 10 \\
\hline
\end{tabular}

\subsection{Column Testing with Simulant}

Two small scale ion-exchange column experiments were performed using samples of the 2010 ORNL prepared ${ }^{\mathrm{E}} \mathrm{MST}$ and the peroxide treated ${ }^{\mathrm{E}} \mathrm{mMST}$. A total of 30-L of simulant was prepared (15-L per column), having the composition shown in Table 2-7. A schematic of the column is shown in Figure 2-1, and arrangement of the equipment is shown in Figure 2-2. The glass columns had an internal diameter of $11 \mathrm{~mm}$, and had $1 \mathrm{~mm}$ fine graduations on the glass. The pumps used to supply feed to each column were Fluid Metering Inc (FMI) pumps possessing a QG20 motor with a Q0 stainless steel piston, 1/8" diameter. The samples of EST and peroxide treated ${ }^{\mathrm{E}} \mathrm{mMST}$ were pre-soaked in a non-rad, sorbate free salt solution prior to loading in the columns. The composition of this solution is provided in Table 2-8. The salt solution was treated with MST prior to use to remove any tramp Sr. Specifically, $1.80775 \mathrm{~g}$ of ${ }^{\mathrm{E}} \mathrm{MST}$ and $1.80162 \mathrm{~g}$ of peroxide treated ${ }^{\mathrm{E}} \mathrm{mMST}$ were placed in glass vials. Aliquots $(10-\mathrm{mL})$ of the salt solution were then added and the materials were left to soak for several days before the start of the column experiment. During this soaking period, it was observed that the ${ }^{\mathrm{E}} \mathrm{MST}$ material swelled considerably, compared to the peroxide treated ${ }^{\mathrm{E}} \mathrm{mMST}$, which did not appear to swell. 
Table 2-7. Composition of Simulant Used for Column Testing.

\begin{tabular}{|c|c|c|}
\hline Component & Target & Measured \\
\hline Free $\mathbf{N a O H}$ & $2.21 \mathrm{M}$ & $1.90 \mathrm{M}$ \\
\hline Total $_{\mathbf{~ N a N O}} \mathbf{}_{\mathbf{3}}$ & $2.03 \mathrm{M}$ & $2.05 \mathrm{M}$ \\
\hline $\mathbf{N a A l}(\mathbf{O H})_{4}$ & $0.280 \mathrm{M}$ & $0.275 \mathrm{M}$ \\
\hline $\mathbf{N a N O}_{\mathbf{2}}$ & $0.500 \mathrm{M}$ & $0.548 \mathrm{M}$ \\
\hline $\mathbf{N a}_{2} \mathbf{S O}_{\mathbf{4}}$ & $0.140 \mathrm{M}$ & $0.131 \mathrm{M}$ \\
\hline $\mathbf{N a}_{\mathbf{2}} \mathbf{C O}_{\mathbf{3}}$ & $0.150 \mathrm{M}$ & $0.151 \mathrm{M}$ \\
\hline $\mathbf{T o t a l}_{\mathbf{N a}}$ & $5.6 \mathrm{M}$ & $5.38 \mathrm{M}$ \\
\hline${ }^{85} \mathbf{S r}$ & $30,000 \mathrm{dpm} / \mathrm{mL}$ & $7,180 \mathrm{dpm} / \mathrm{mL}$ \\
\hline Total $\mathbf{S r}$ & $6.00 \mathrm{mg} / \mathrm{L}$ & $0.603 \mathrm{mg} / \mathrm{L}$ \\
\hline${ }^{137} \mathbf{C s}$ & $30,000 \mathrm{dpm} / \mathrm{mL}$ & $39,400 \mathrm{dpm} / \mathrm{mL}$ \\
\hline Total $\mathbf{C s}$ & $18.6 \mathrm{mg} / \mathrm{L}$ & $16.8 \mathrm{mg} / \mathrm{L}$ \\
\hline $\mathbf{P u}$ & $200 \mu \mathrm{g} / \mathrm{L}$ & $162 \mu \mathrm{g} / \mathrm{L}$ \\
\hline $\mathbf{N p}$ & $500 \mu \mathrm{g} / \mathrm{L}$ & $500 \mu \mathrm{g} / \mathrm{L}$ \\
\hline $\mathbf{U}$ & $10,000 \mu \mathrm{g} / \mathrm{L}$ & $4,320 \mu \mathrm{g} / \mathrm{L}$ \\
\hline
\end{tabular}

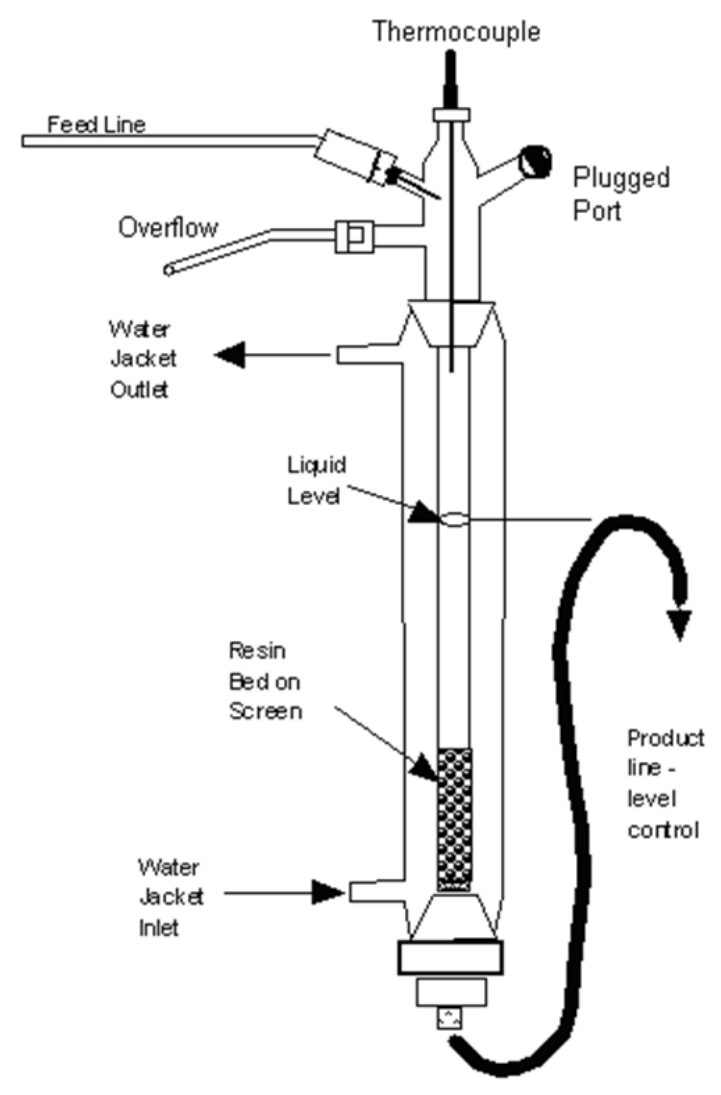

Figure 2-1. Ion-Exchange Column Design. 
SRNL-STI-2012-00193

Revision 0

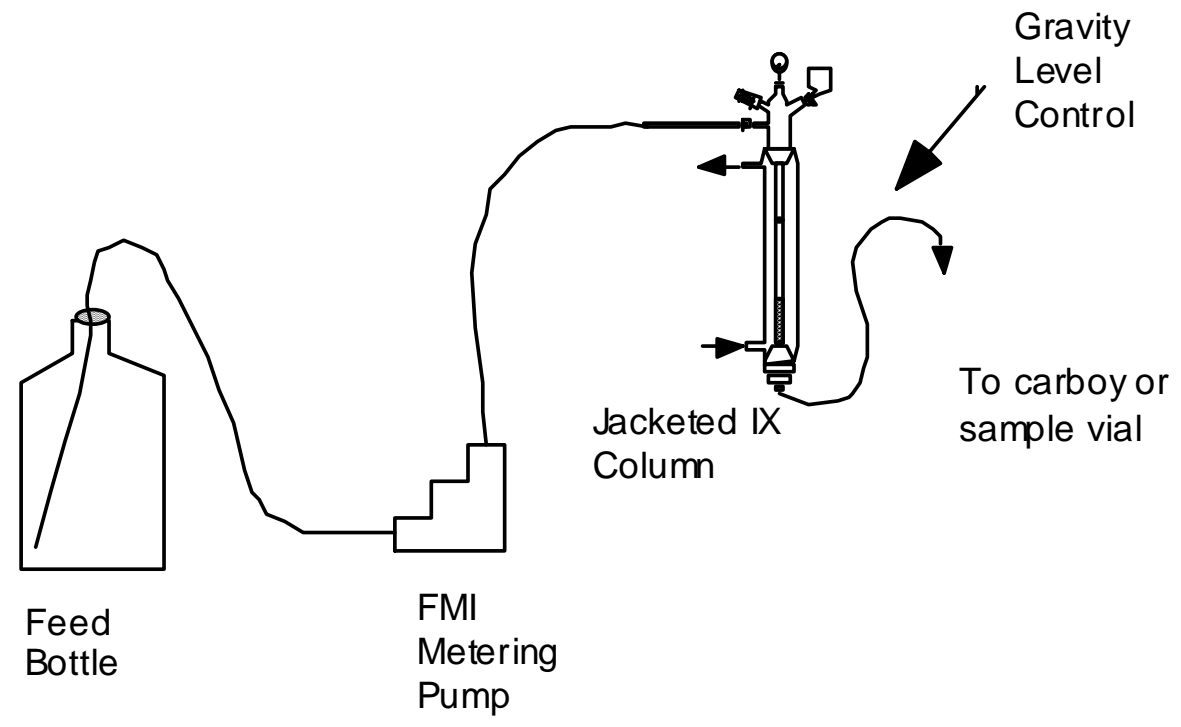

Figure 2-2. Schematic of Column Set-Up.

Table 2-8. Composition of Salt Solution Used for Pre-Soaking Materials for Column (SWS1-2010).

\begin{tabular}{|c|c|}
\hline Component & Target Concentration \\
\hline Free $\mathrm{NaOH}$ & $1.33 \mathrm{M}$ \\
\hline $\mathrm{NaNO}_{3}$ & $2.90 \mathrm{M}$ \\
\hline $\mathrm{NaNO}_{2}$ & $0.149 \mathrm{M}$ \\
\hline $\mathrm{Na}_{2} \mathrm{SO}_{4}$ & $0.581 \mathrm{M}$ \\
\hline $\mathrm{Na}_{2} \mathrm{CO}_{3}$ & $0.029 \mathrm{M}$ \\
\hline Total Na & $5.6 \mathrm{M}$ \\
\hline
\end{tabular}

The soaked materials were then transferred into the columns along with the salt solution. The 15-L of simulant (per column) was then passed through the column at a flow rate of approximately $0.5 \mathrm{~mL} / \mathrm{min}$. The temperature of the columns was controlled throughout the experiment using a temperature controlled recirculating waterbath set at $25{ }^{\circ} \mathrm{C}$ to circulate water through the column jacket. Samples were collected throughout the experiment. Each sample was collected over a period of approximately 10 minutes. The sample size was determined by the difference in the vial mass before and after collecting the sample. Sample collections were timed, and this information was also used to calculate the current flow rate, to insure there was no drift. Samples were then acidified by the addition of $6 \mathrm{~mL}$ of $5 \mathrm{M}$ nitric acid. The precise amount of acid added was also determined by the difference in mass. The acidified samples were then submitted for ICP-MS, gamma scan, and PuTTA analyses.

After the column experiment was complete the resin beads were removed from the columns and representative samples were digested for analysis. Approximately $0.05 \mathrm{~g}$ of the air dried material from each column was placed into a $50-\mathrm{mL}$ glass beaker. Two $\mathrm{mL}$ of distilled water and $2 \mathrm{~mL}$ of concentrated sulfuric acid were then added to each beaker. The mixtures were placed on a stirring hot plate, and were stirred and heated until all of the solids dissolved. The solutions were allowed to cool, and were then transferred to $25-\mathrm{mL}$ volumetric flasks and diluted to volume with distilled water. Samples of these solutions were then submitted for gamma scan, PuTTA, ICPMS, and ICP-ES analyses. 


\subsection{Results and Discussion}

\subsection{Characterization of Materials}

\subsubsection{Photographs}

Photos of the ${ }^{\mathrm{E}}$ MST and ${ }^{\mathrm{E}} \mathrm{mMST}$ samples were acquired at higher magnification using an optical microscope equipped with a still camera. Images in Figures 3-1 through 3-4 show the particles are generally spherical, although there are some irregular shaped particles. Post-treatment of the materials with $\mathrm{H}_{2} \mathrm{O}_{2}$ did not affect the size and morphology of the particles.
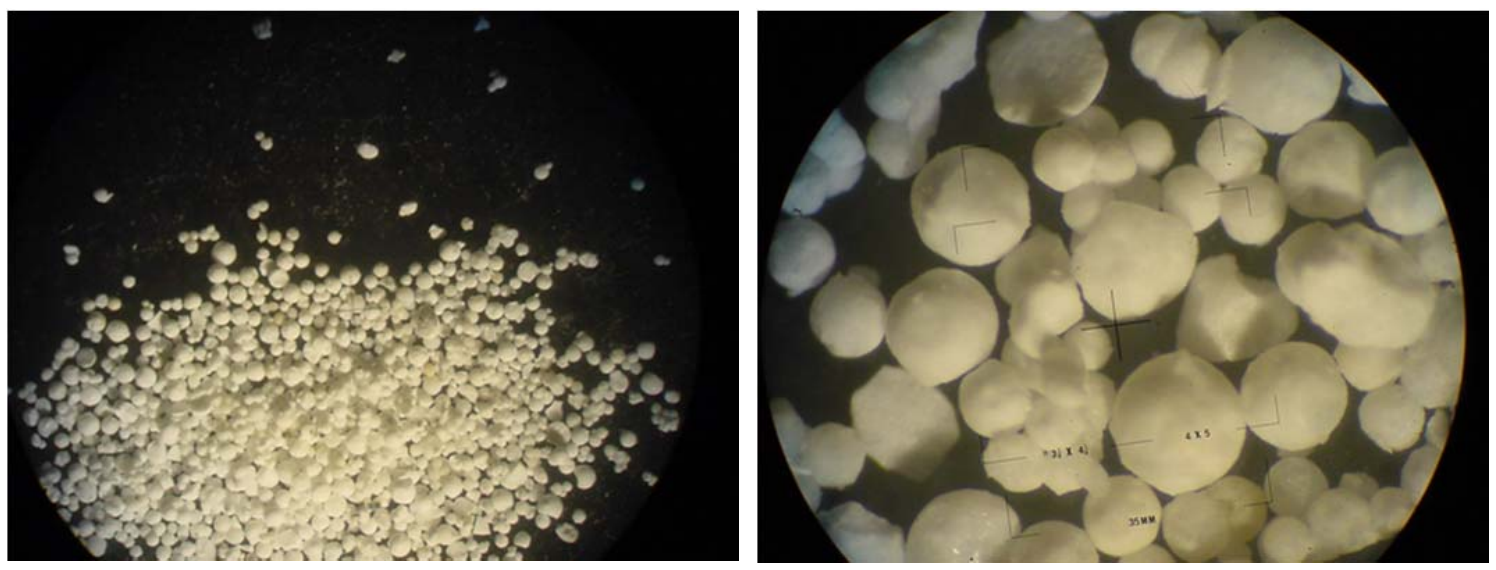

Figure 3-1. Photos of 2010 ORNL prepared ${ }^{\mathrm{E}} \mathrm{MST}$ at 10x (left) and 55x (right) magnification.
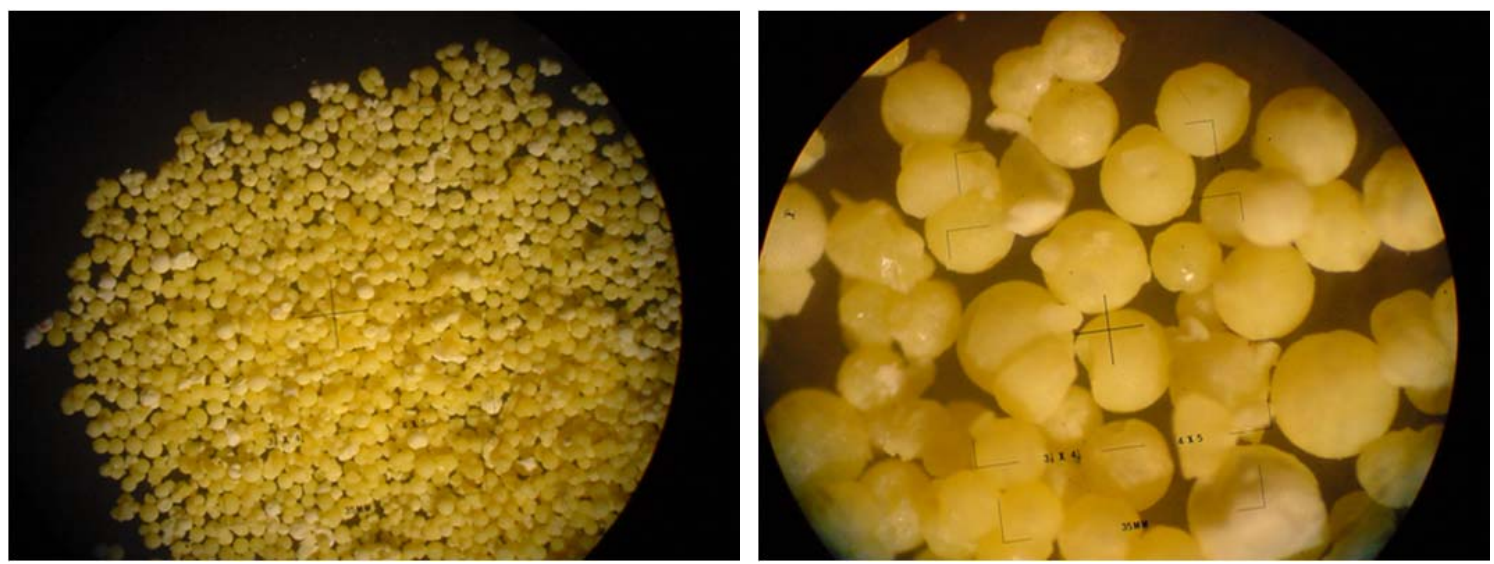

Figure 3-2. Photos of 2010 ORNL prepared ${ }^{\mathrm{E}} \mathrm{mMST}$ at 10x (left) and 55x (right) magnification. 

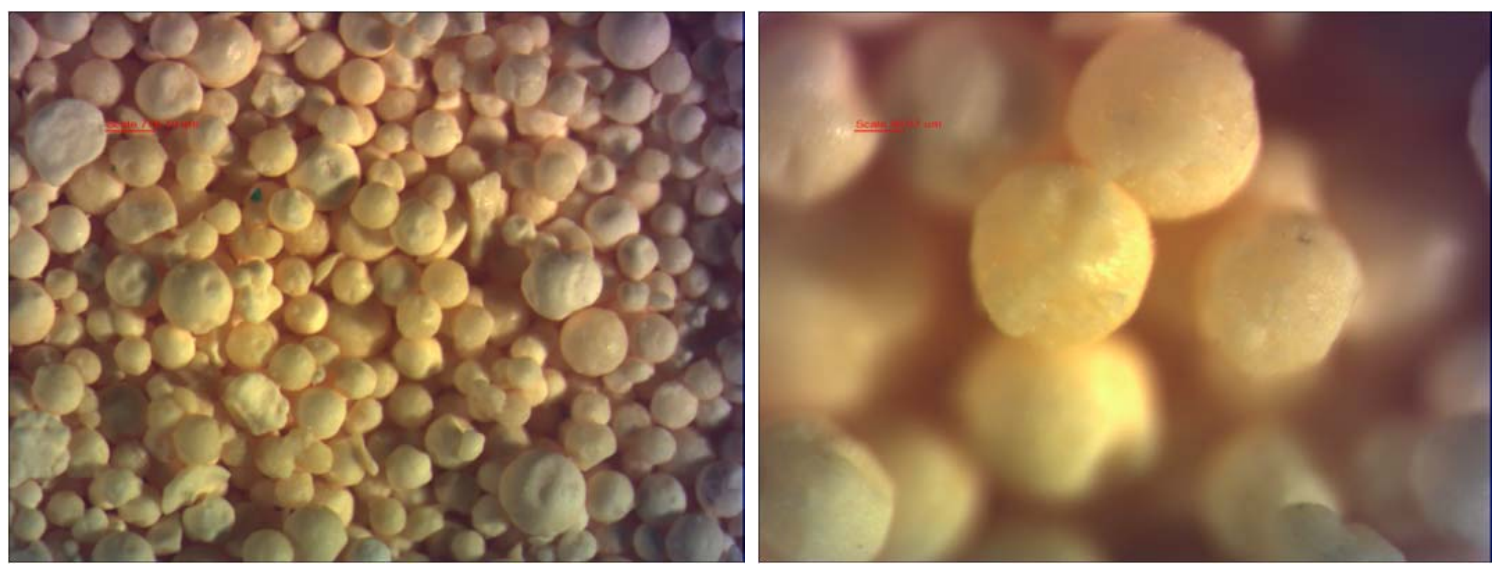

Figure 3-3. Photos of peroxide treated ${ }^{\mathrm{E}} \mathrm{MST}$ at 16x (left) and 63x (right) magnification.
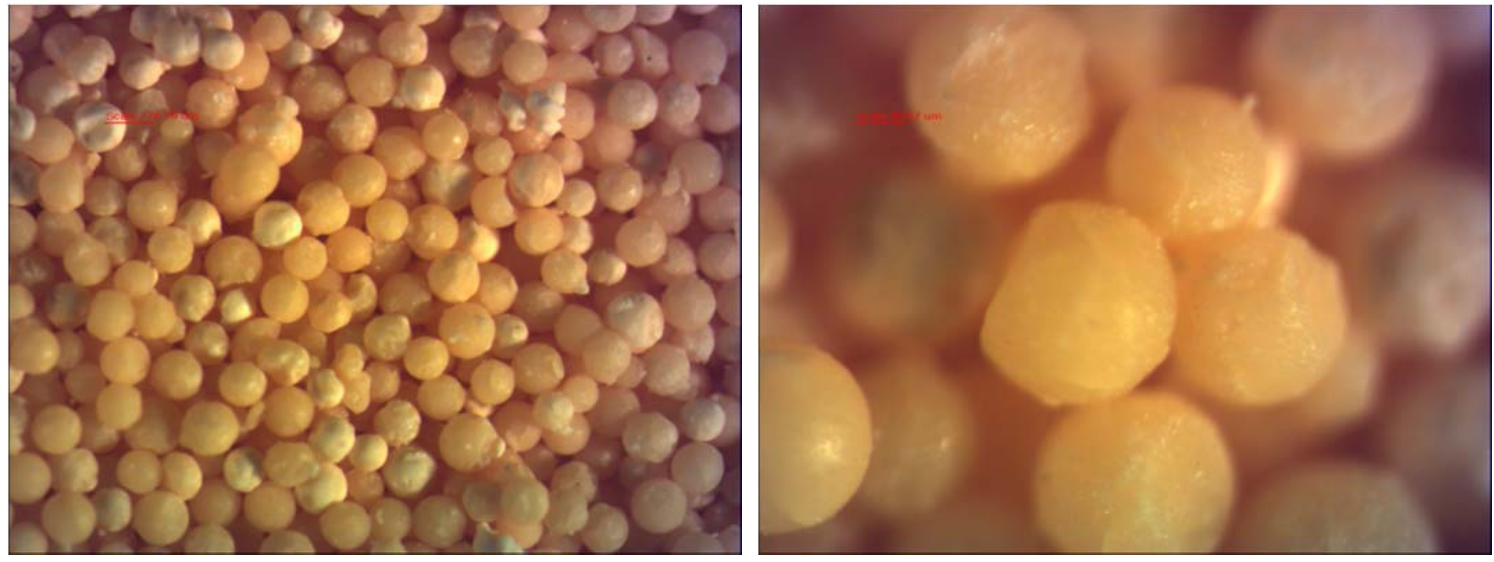

Figure 3-4. Photos of peroxide treated ${ }^{\mathrm{E}} \mathrm{mMST}$ at $16 \mathrm{x}$ (left) and $63 \mathrm{x}$ (right) magnifications.

\subsubsection{Powder X-ray Diffraction}

Samples of the 2010 ORNL prepared ${ }^{\mathrm{E}} \mathrm{MST}$ and ${ }^{\mathrm{E}} \mathrm{mMST}$ and the peroxide treated versions of both materials were analyzed using PXRD. Figure 3-5 compares the diffraction pattern of the ${ }^{\mathrm{E}}$ MST to a sample of non-engineered MST. The peak at 8.7 two theta in the non-engineered MST was slightly shifted to a two theta value of 9.2 in the engineered form. This shift is consistent with a decrease in d-spacing, indicating a decrease in spacing between the layers likely due to dehydration. Comparison of ${ }^{\mathrm{E}} \mathrm{mMST}$ to non-engineered mMST (Figure 3-6) indicated that the engineered material is more amorphous than the non-engineered mMST. Post treatment of the materials with peroxide did not result in changes to the diffraction patterns for either material (Figures 3-7 and 3-8). 
SRNL-STI-2012-00193

Revision 0

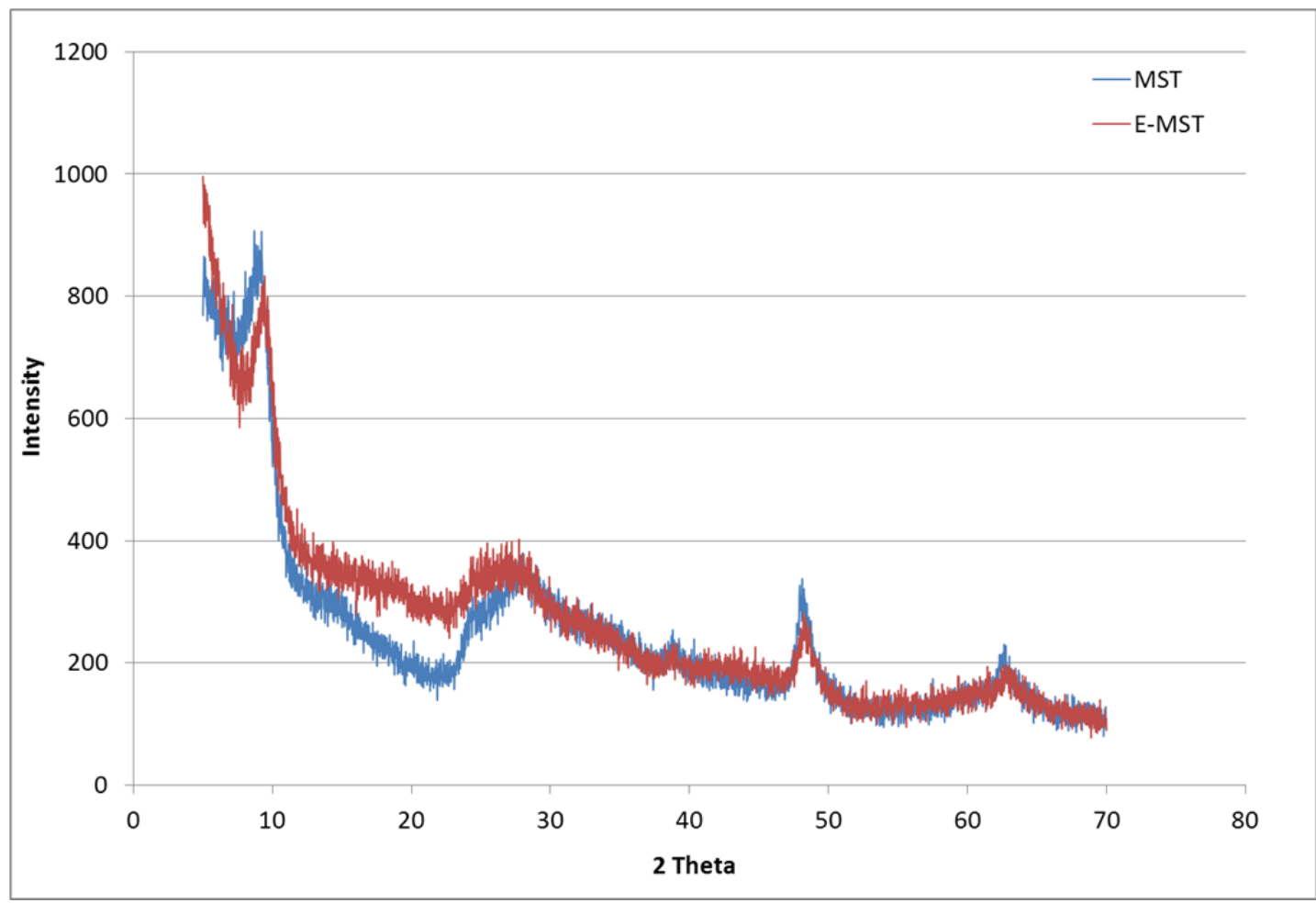

Figure 3-5. PXRD of MST and ${ }^{\mathrm{E}} \mathrm{MST}$.

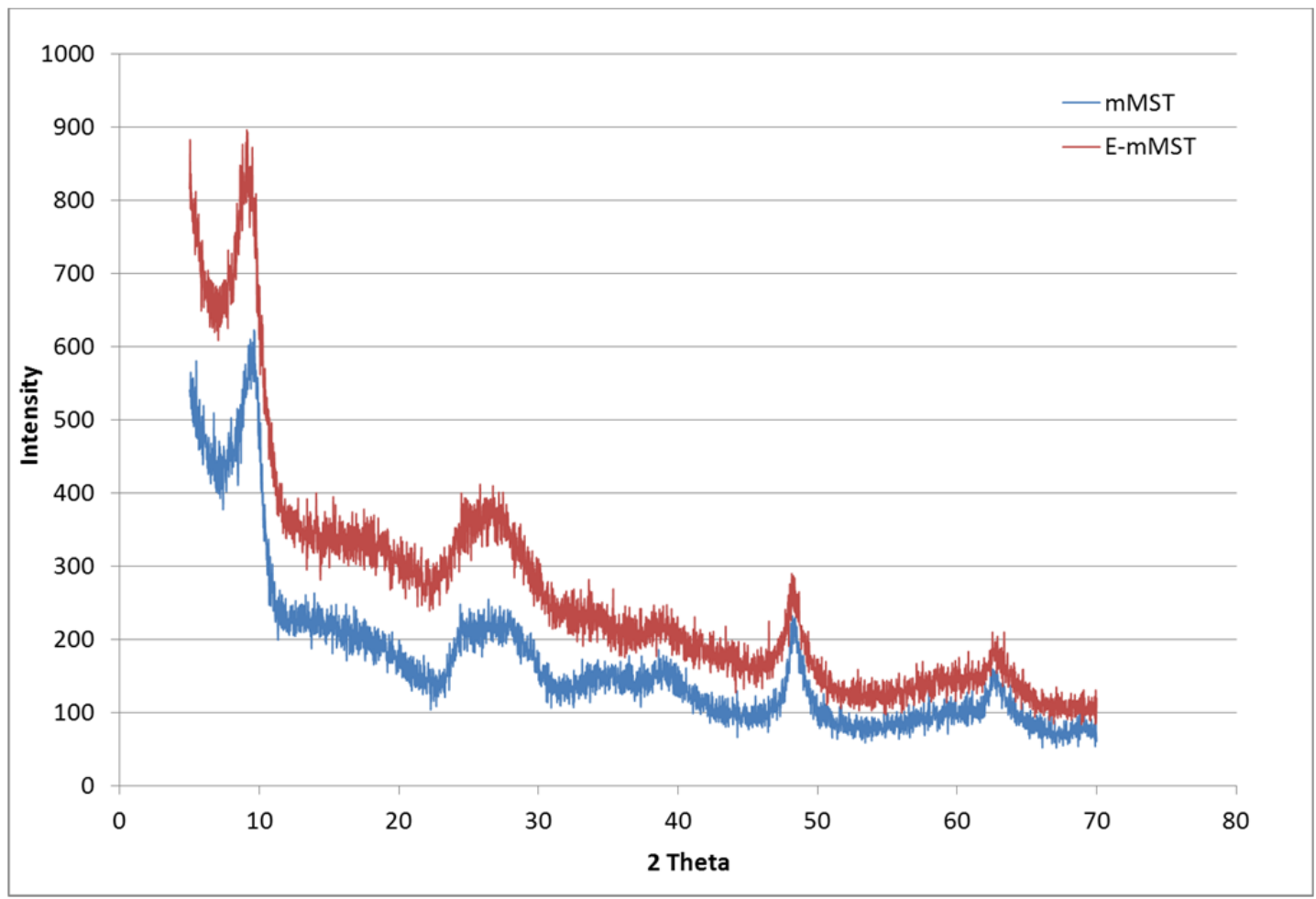

Figure 3-6. PXRD of mMST and ${ }^{\mathrm{E}} \mathrm{mMST}$. 


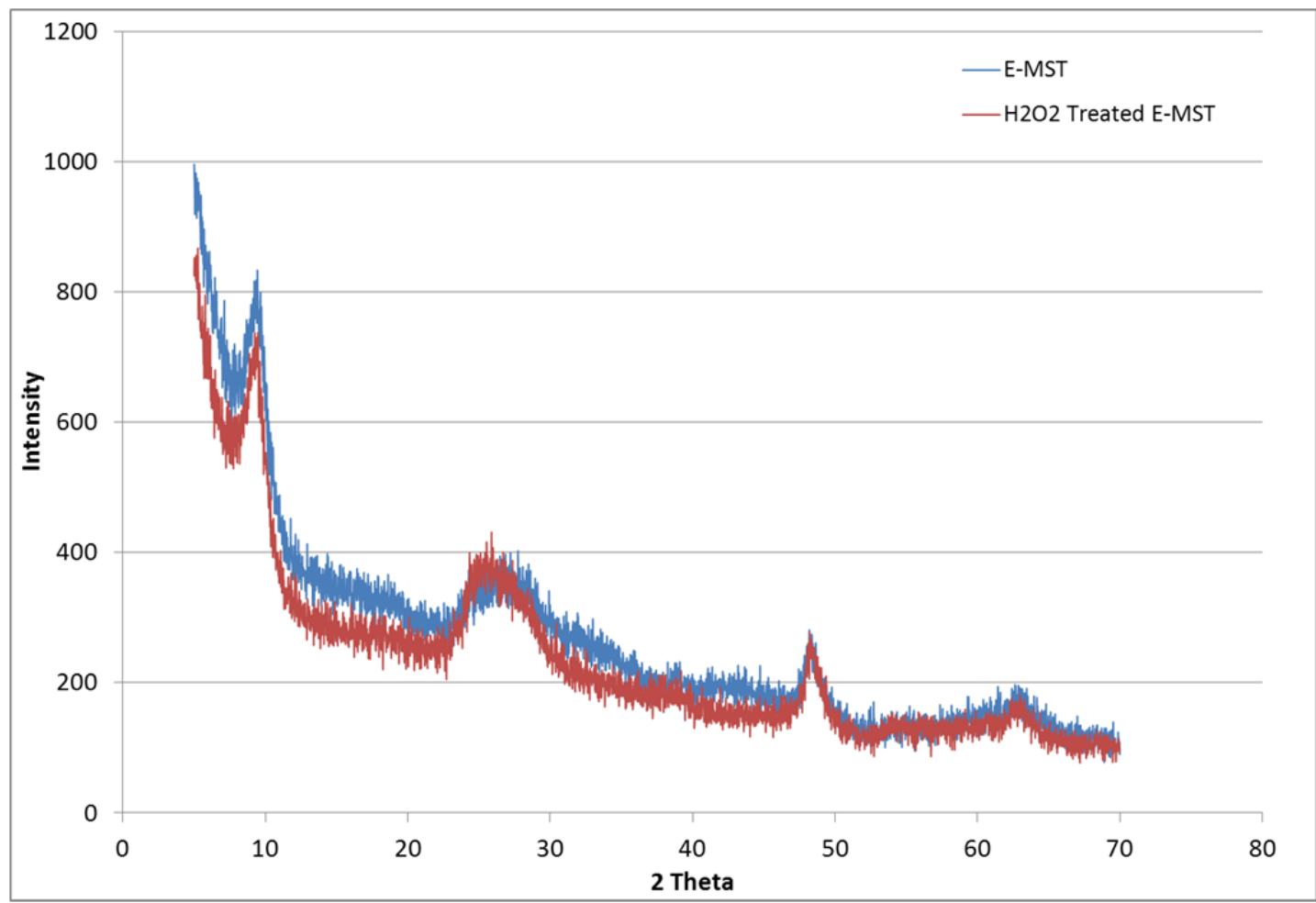

Figure 3-7. PXRD of ${ }^{\mathrm{E}}$ MST before and after peroxide treatment.

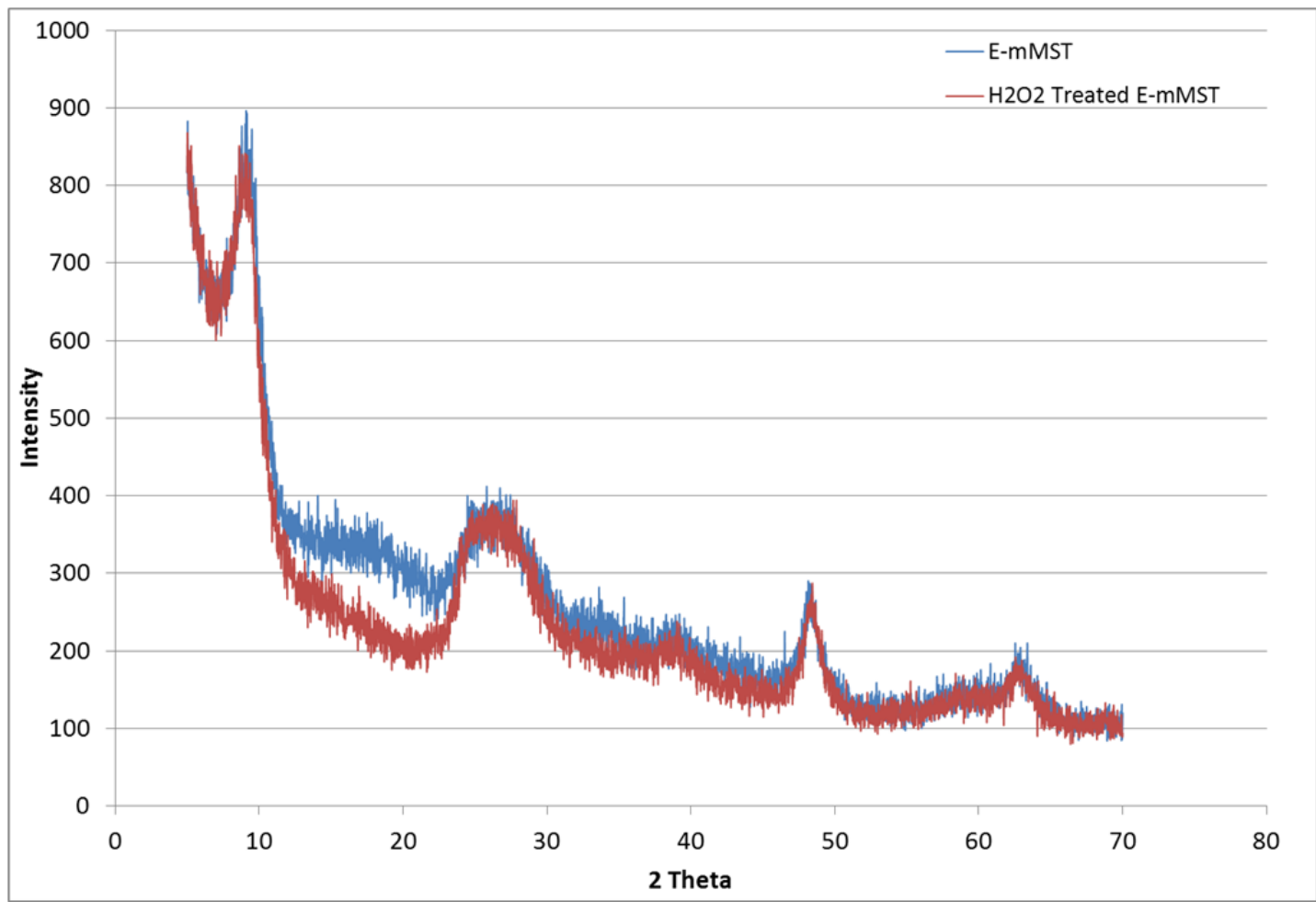

Figure 3-8. PXRD of ${ }^{\mathrm{E}} \mathrm{mMST}$ before and after peroxide treatment. 


\subsubsection{Particle Size Analysis}

Samples of the 2010 ORNL prepared ${ }^{\mathrm{E}} \mathrm{MST}$ and ${ }^{\mathrm{E}} \mathrm{mMST}$ were analyzed for both number and volume particle size distributions. The results are shown in Figures 3-9 (number) and 3-10 (volume). The number distributions were centered around $500 \mu \mathrm{m}$ for both the ${ }^{\mathrm{E}} \mathrm{MST}$ and the ${ }^{\mathrm{E}} \mathrm{mMST}$ and the majority of particles are in the range of $200-800 \mu \mathrm{m}$. The volume distributions were centered around $550 \mu \mathrm{m}$ for both materials. Samples of the peroxide treated materials were also analyzed for particle size distributions, and as shown in Figures 3-9 and 3-10, the particle size distributions shifted to slightly smaller particle size after the peroxide treatment.

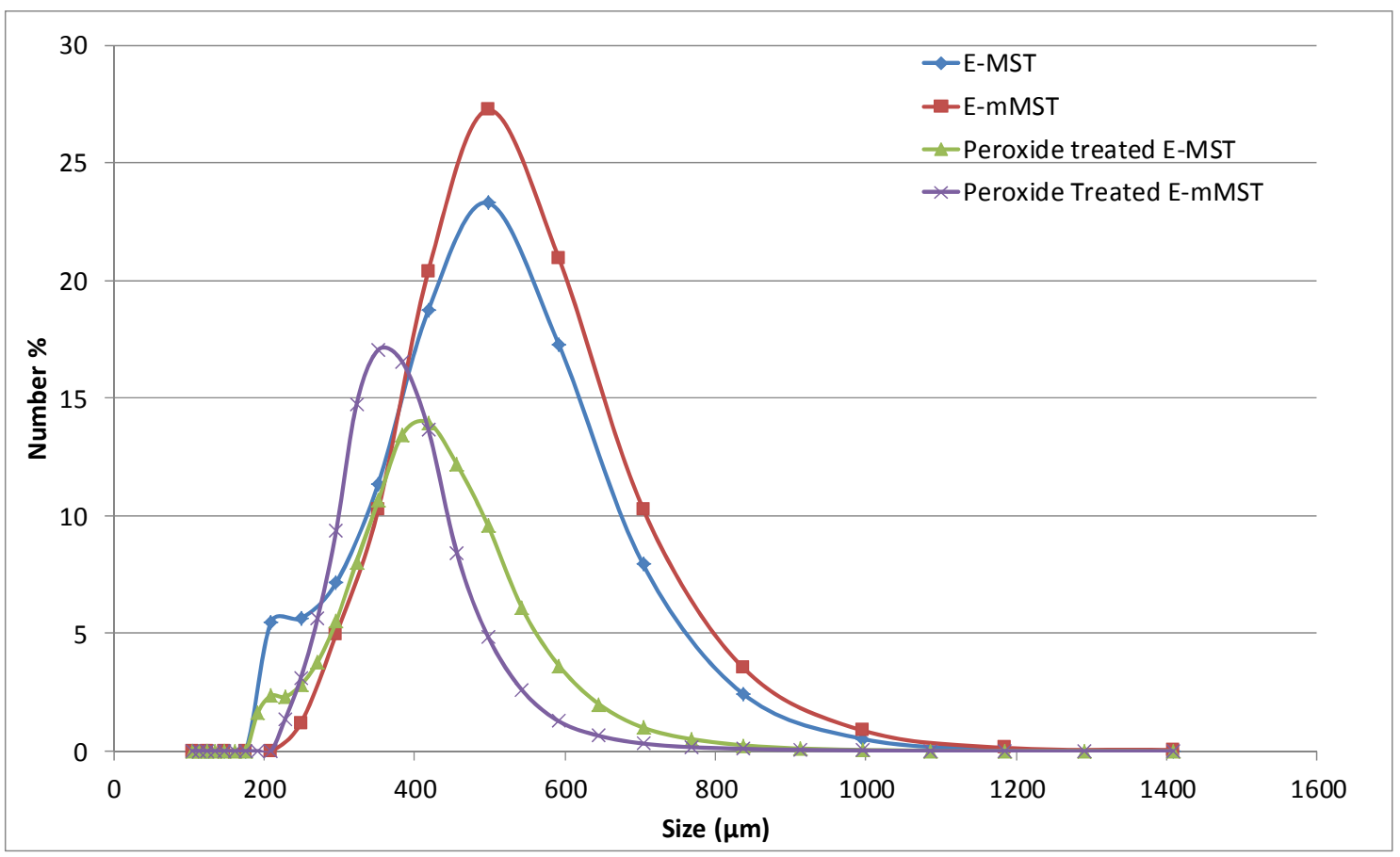

Figure 3-9. Number based particle size distribution of ${ }^{\mathrm{E}} \mathrm{MST},{ }^{\mathrm{E}} \mathrm{mMST}$, and the peroxide treated versions of both. 


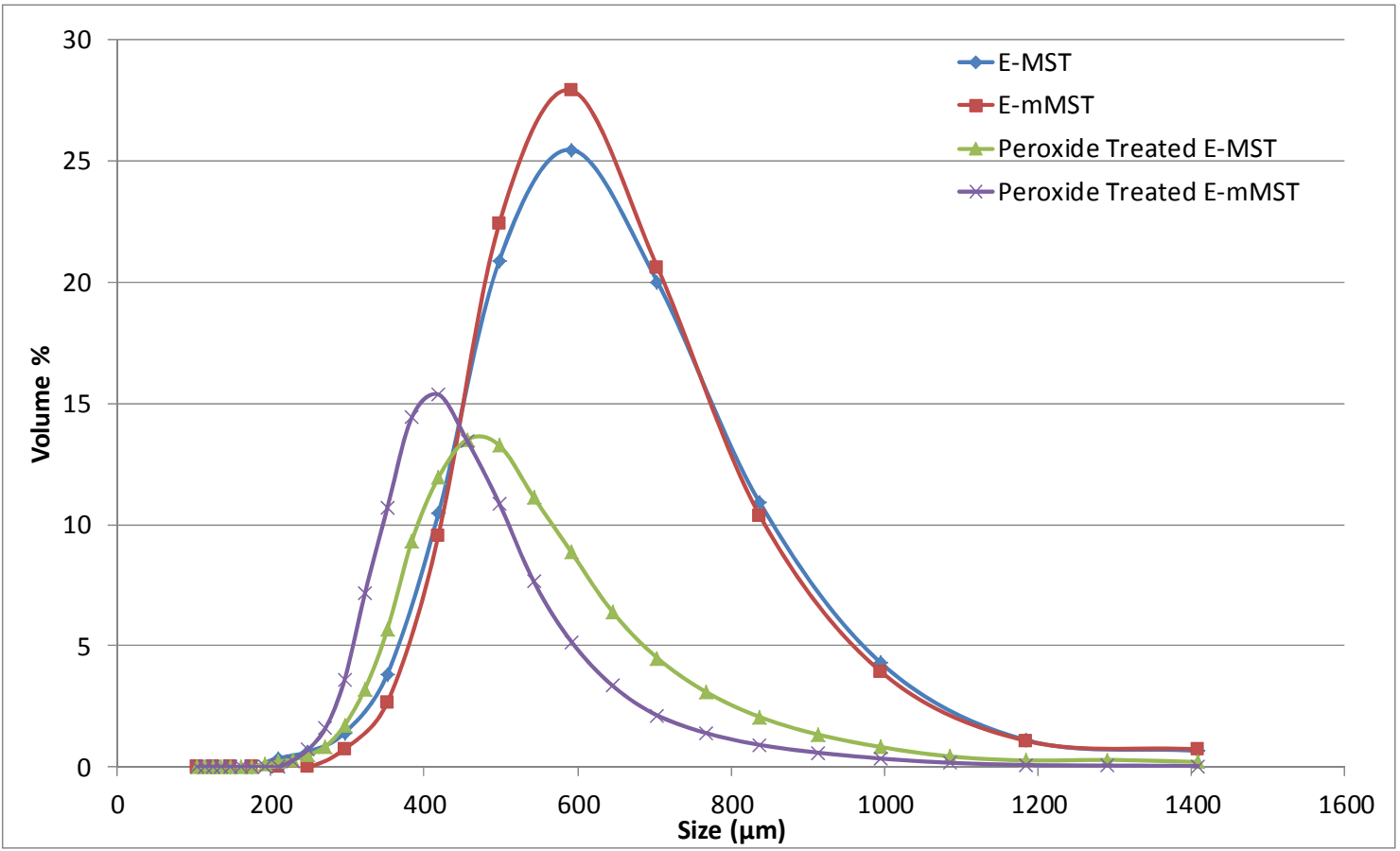

Figure 3-10. Volume based particle size distribution of ${ }^{\mathrm{E}} \mathrm{MST},{ }^{\mathrm{E}} \mathrm{mMST}$, and the peroxide treated versions of both.

\subsubsection{Thermogravimetric Analysis (TGA)}

Samples of the 2010 ORNL prepared ${ }^{\mathrm{E}}$ MST and ${ }^{\mathrm{E}} \mathrm{mMST}$ were analyzed using TGA. The samples were heated from room temperature to $600{ }^{\circ} \mathrm{C}$ at a rate of $5{ }^{\circ} \mathrm{C}$ per minute. The results are shown in Figure 3-11. The results show both the loss of water and organic material.

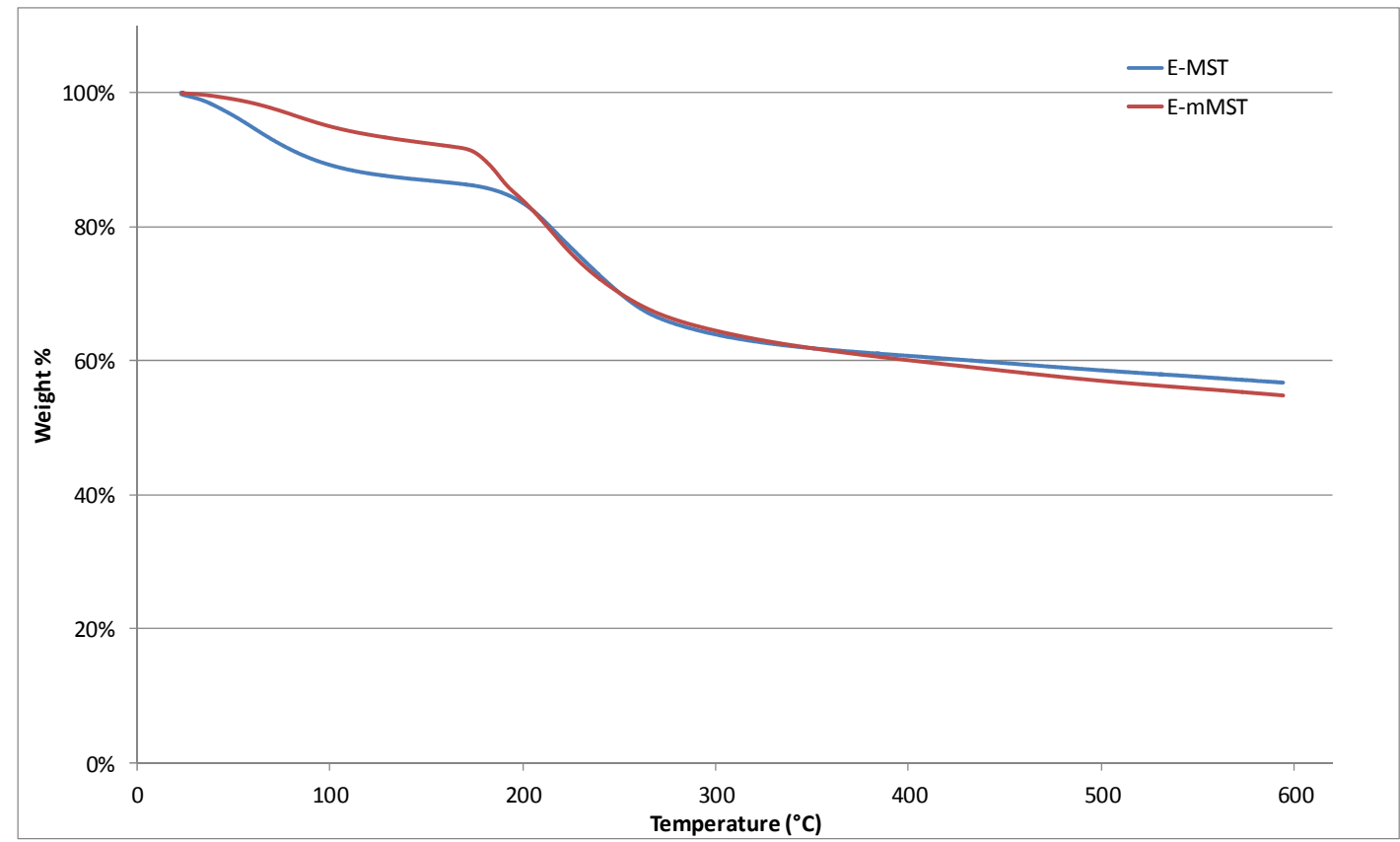

Figure 3-11. TGA of 2010 ORNL Prepared Samples of ${ }^{\mathrm{E}}$ MST and ${ }^{\mathrm{E}} \mathrm{mMST}$. 


\subsubsection{Tap Densities}

The tap densities of the 2010 ORNL prepared were measured using the procedure described in Section 2.2. The results are provided in Table 3-1. The ${ }^{\mathrm{E}} \mathrm{mMST}$ was found to have a higher tapped density $(1.108 \mathrm{~g} / \mathrm{mL})$ than the ${ }^{\mathrm{E}} \mathrm{MST}(0.941 \mathrm{~g} / \mathrm{mL})$.

Table 3-1. Tap Densities of ${ }^{\mathrm{E}} \mathrm{MST}$ and ${ }^{\mathrm{E}} \mathrm{mMST}$.

\begin{tabular}{|c|c|c|}
\hline & ${ }^{\mathrm{E}} \mathbf{M S T}$ & ${ }^{\mathrm{E}} \mathbf{m M S T}$ \\
\hline Trial 1 & $0.930 \mathrm{~g} / \mathrm{mL}$ & $1.106 \mathrm{~g} / \mathrm{mL}$ \\
\hline Trial 2 & $0.958 \mathrm{~g} / \mathrm{mL}$ & $1.107 \mathrm{~g} / \mathrm{mL}$ \\
\hline Trial 3 & $0.935 \mathrm{~g} / \mathrm{mL}$ & $1.110 \mathrm{~g} / \mathrm{mL}$ \\
\hline Average & $\mathbf{0 . 9 4 1} \mathbf{g} / \mathbf{m L}$ & $\mathbf{1 . 1 0 8} \mathbf{g} / \mathbf{m L}$ \\
\hline Standard Deviation & $0.0151 \mathrm{~g} / \mathrm{mL}$ & $0.0023 \mathrm{~g} / \mathrm{mL}$ \\
\hline
\end{tabular}

\subsubsection{Elemental Analysis}

Samples of the 2010 ORNL prepared ${ }^{\mathrm{E}}$ MST and ${ }^{\mathrm{E}} \mathrm{mMST}$ were digested as described in Section 2.2 and the solutions were submitted for ICP-ES and TIC/TOC analyses. Results of the analysis are provided in Table 3-2. Analysis showed that the two materials had similar Ti contents, $29.58 \mathrm{wt} \%$ and $28.50 \mathrm{wt} \%$ for ${ }^{\mathrm{E}} \mathrm{MST}$ and ${ }^{\mathrm{E}} \mathrm{mMST}$, respectively. The materials had very low Na contents, with the Na content for the ${ }^{\mathrm{E}} \mathrm{mMST}$ being below the detection limit. The theoretical Ti:Na ratio for MST is 2. Higher Ti:Na ratios were expected in the engineered material due to additional Ti from the hydrous $\mathrm{TiO}_{\mathrm{x}} \cdot \mathrm{H}_{2} \mathrm{O}$ binder. In addition, the MST is likely in the protonated form due to the internal gelation process. Modified MST is expected to have a higher Ti:Na ratio than MST as the mMST is adjusted to a $\mathrm{pH}$ of 4 after synthesis before storage as $15 \mathrm{wt} \%$ slurry. The materials also had a higher organic content than expected. The ${ }^{\mathrm{E}} \mathrm{MST}$ contained $0.40 \mathrm{wt} \% \mathrm{C}$, while the ${ }^{\mathrm{E}} \mathrm{mMST}$ contained $0.84 \mathrm{wt} \% \mathrm{C}$. The presence of organic material is due to the internal gelation process used to prepare the materials.

Table 3-2. Results from ICP-ES and TIC/TOC analyses of ${ }^{\mathrm{E}} \mathrm{MST}$ and ${ }^{\mathrm{E}} \mathrm{mMST}$.

\begin{tabular}{|c|c|c|c|c|c|c|c|}
\hline & $\begin{array}{c}\mathrm{Na}(\mathrm{mg} / \mathrm{L}) \\
(\% \text { RSD) }\end{array}$ & $\begin{array}{c}\text { Ti (mg/L) } \\
\text { (\%RSD) }\end{array}$ & $\begin{array}{c}\text { wt \% } \\
\mathrm{Ti}\end{array}$ & $\begin{array}{c}\text { Ti:Na Molar } \\
\text { Ratio } \\
\end{array}$ & $\begin{array}{c}\text { TIC } \\
(\mu \mathrm{g} / \mathrm{g})\end{array}$ & $\begin{array}{c}\text { TOC } \\
(\mu \mathrm{g} / \mathrm{g})\end{array}$ & $\begin{array}{l}\text { wt \% } \\
\text { Total C }\end{array}$ \\
\hline${ }^{\mathbf{E}}$ MST-1 & $6.1(20.2 \%)$ & $\begin{array}{c}295 \\
(10.3 \%)\end{array}$ & 28.62 & 23.2 & 26.2 & 4016 & $0.40 \mathrm{wt} \%$ \\
\hline${ }^{\mathrm{E}}$ MST-2 & $6.24(53 \%)$ & $\begin{array}{c}306 \\
(11.3 \%)\end{array}$ & 30.55 & 23.4 & - & - & - \\
\hline Ave. ${ }^{\mathrm{E}}$ MST & 6.17 & 300 & 29.58 & 23.3 & 26.2 & 4016 & $0.40 \mathrm{wt} \%$ \\
\hline${ }^{\mathrm{E}} \mathrm{mMST}-1$ & $<5.6$ & $\begin{array}{c}277 \\
(10.2 \%) \\
\end{array}$ & 27.65 & $>23.8$ & 118 & 8260 & $0.84 \mathrm{wt} \%$ \\
\hline${ }^{E_{m M S T-2}}$ & $<5.6$ & $\begin{array}{c}297 \\
(10.7 \%)\end{array}$ & 29.34 & $>25.5$ & - & - & - \\
\hline Ave. ${ }^{\mathrm{E}} \mathrm{mMST}$ & $<5.6$ & 287 & 28.50 & $>24.6$ & 118 & 8260 & 0.84 wt $\%$ \\
\hline
\end{tabular}

\subsubsection{Iodometric Titrations}

Samples of both the 2010 ORNL prepared ${ }^{\mathrm{E}} \mathrm{MST}$ and ${ }^{\mathrm{E}} \mathrm{mMST}$ and the peroxide treated versions of each were analyzed using the iodometric titration method to determine the amount of peroxide in the materials. The ${ }^{\mathrm{E}} \mathrm{mMST}$ material had a much lower $(6.6 \%) \mathrm{H}_{2} \mathrm{O}_{2}$ :Ti ratio than what is seen for freshly prepared mMST, and the peroxide content increased only slightly $(\sim 10 \%)$ after the additional peroxide treatment. The ${ }^{\mathrm{E}} \mathrm{MST}$ material contained little to no peroxide, as expected, and the peroxide treatment was able to incorporate some peroxide; however, the $\mathrm{H}_{2} \mathrm{O}_{2}$ :Ti ratio was still less than that of the ${ }^{\mathrm{E}} \mathrm{mMST}$. The results from these measurements are summarized in Table 3-3. 
SRNL-STI-2012-00193

Revision 0

Table 3-3. Results of Iodometric Titratons.

\begin{tabular}{|c|c|}
\hline & Peroxide:Ti Molar Ratio (Std. Dev.) \\
\hline${ }^{\mathrm{E}}$ MST Trial 1 & $<0.001$ \\
\hline${ }^{\mathrm{E}}$ MST Trial 2 & $<0.001$ \\
\hline${ }^{\mathrm{E}}$ MST Trial 3 & $<0.003$ \\
\hline Average $^{\mathrm{E}}$ MST & $<0.002(0.001)$ \\
\hline${ }^{\mathrm{E}} \mathrm{mMST}$ Trial 1 & 0.021 \\
\hline${ }^{\mathrm{E}}$ mMST Trial 2 & 0.023 \\
\hline${ }^{E}$ mMST Trial 3 & 0.021 \\
\hline Average ${ }^{\mathrm{E}} \mathrm{mMST}$ & $0.022(0.001)$ \\
\hline $\mathrm{H}_{2} \mathrm{O}_{2}$ Treated ${ }^{\mathrm{E}}$ MST Trial 1 & 0.012 \\
\hline $\mathrm{H}_{2} \mathrm{O}_{2}$ Treated ${ }^{\mathrm{E}}$ MST Trial 2 & $\begin{array}{c}0.016 \text { (not included in average, } \\
\text { overshot endpoint) }\end{array}$ \\
\hline $\mathrm{H}_{2} \mathrm{O}_{2}$ Treated ${ }^{\mathrm{E}} \mathrm{MST}$ Trial 3 & 0.014 \\
\hline Average $\mathrm{H}_{2} \mathrm{O}_{2}$ Treated ${ }^{\mathrm{E}} \mathrm{MST}$ & $0.013(0.001)$ \\
\hline $\mathrm{H}_{2} \mathrm{O}_{2}$ Treated ${ }^{\mathrm{E}} \mathrm{mMST}$ Trial 1 & 0.024 \\
\hline $\mathrm{H}_{2} \mathrm{O}_{2}$ Treated ${ }^{\mathrm{E}} \mathrm{mMST}$ Trial 2 & 0.024 \\
\hline $\mathrm{H}_{2} \mathrm{O}_{2}$ Treated ${ }^{\mathrm{E}}$ mMST Trial 3 & 0.024 \\
\hline Average $\mathrm{H}_{2} \mathrm{O}_{2}$ Treated ${ }^{\mathrm{E}} \mathrm{mMST}$ & $0.024(0.000)$ \\
\hline mMST (LS-10) at age 0.22 years & $0.327(0.003)$ \\
\hline
\end{tabular}

\subsection{Batch Contact Testing - Effect of Ionic Strength}

Tests ET-1 through ET-14 examined the performance of the 2003 prepared ${ }^{\mathrm{E}} \mathrm{MST}$ in a series of simulated waste solutions with varying ionic strength. A sample of non-engineered MST was also tested in the highest and lowest ionic strength solutions. Six simulant solutions were prepared with target Na concentrations of 5.6, 6.0, 6.5, 7.0, 7.5, and 8.0 M; however, analysis of the simulants showed that the actual Na concentrations were 5.39, 5.65, 5.79, 5.92, 6.44, and 6.83, respectively. In general the decontamination factors (DFs) were found to decrease upon an increase in ionic strength, which is the expected trend and is consistent with prior testing of MST in various ionic strength solutions.

Figure 3-12 provides a plot of the ${ }^{85} \mathrm{Sr}$ DFs versus the sodium concentration of the simulant. There is a large decrease in the DF upon increasing the Na concentration from 5.39 to 5.65, especially at the later time points. The difference in DF obtained in solutions with $\mathrm{Na}$ concentrations ranging from 5.79 to 6.83 does not appear to be significant. A similar trend was seen for $\mathrm{Pu}$, where the greatest effect on DF is upon increasing the $\mathrm{Na}$ concentration from 5.39 to 5.65 (Figure 3-13).

For the ${ }^{\mathrm{E}} \mathrm{MST}$, the Np DF values also decrease upon increasing $\mathrm{Na}$ concentration up to a $\mathrm{Na}$ concentration of 5.92, after which the DF appears to rise with increasing Na concentration (Figure 3-14). However, for the non-engineered MST the Np DF was found to increase when the Na concentration was increased from 5.39 to $6.83 \mathrm{M}$. The U DFs for the ${ }^{\mathrm{E}} \mathrm{MST}$ followed a similar trend to the Sr DFs, where the most drastic decrease in DF was seen when the Na concentration was increased from 5.39 to $5.65 \mathrm{M}$, with less effect over the remaining $\mathrm{Na}$ concentration range (Figure 3-15). However, for the non-engineered MST there was no significant difference in the DFs measured in the 5.39 and $6.83 \mathrm{M} \mathrm{Na}$ simulants. A summary of the DFs for all tests is provided in Appendix A (Table A-1). 


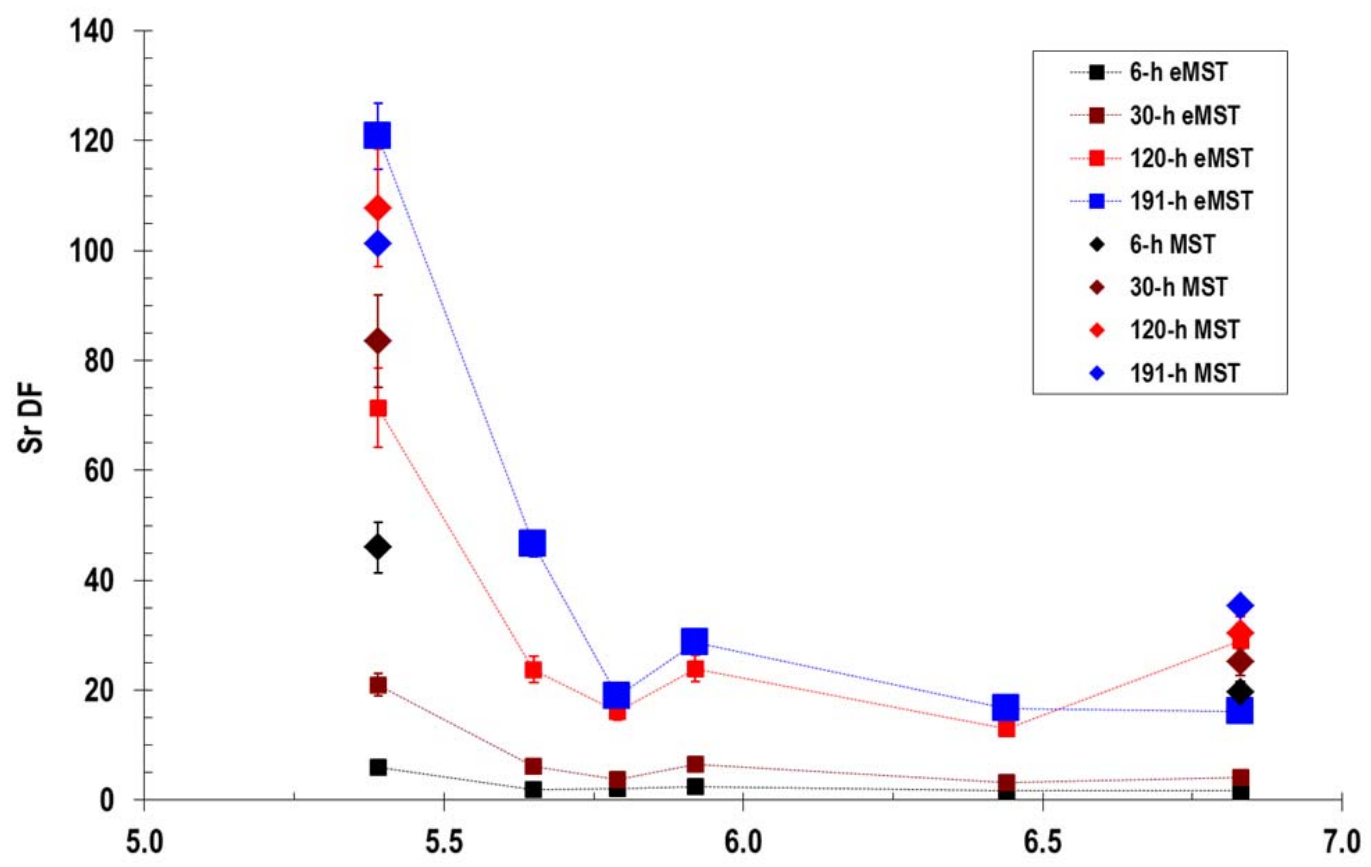

[Na] (M)

Figure 3-12. ${ }^{85} \mathrm{Sr}$ DF values versus Na concentration of the simulant for ${ }^{\mathrm{E}} \mathrm{MST}$ and MST.

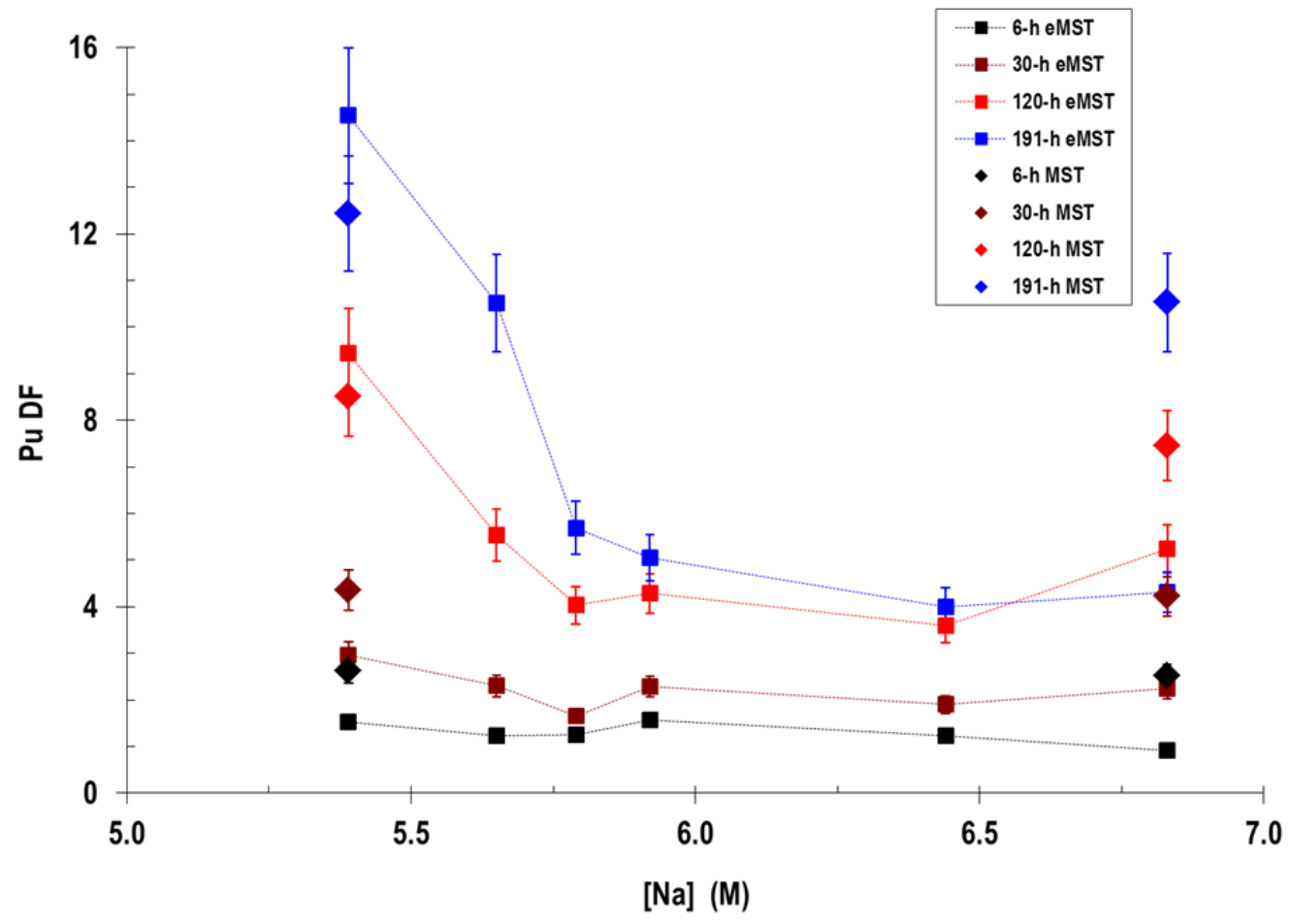

Figure 3-13. Pu DF values versus Na concentration of the simulant for ${ }^{\mathrm{E}} \mathrm{MST}$ and MST. 


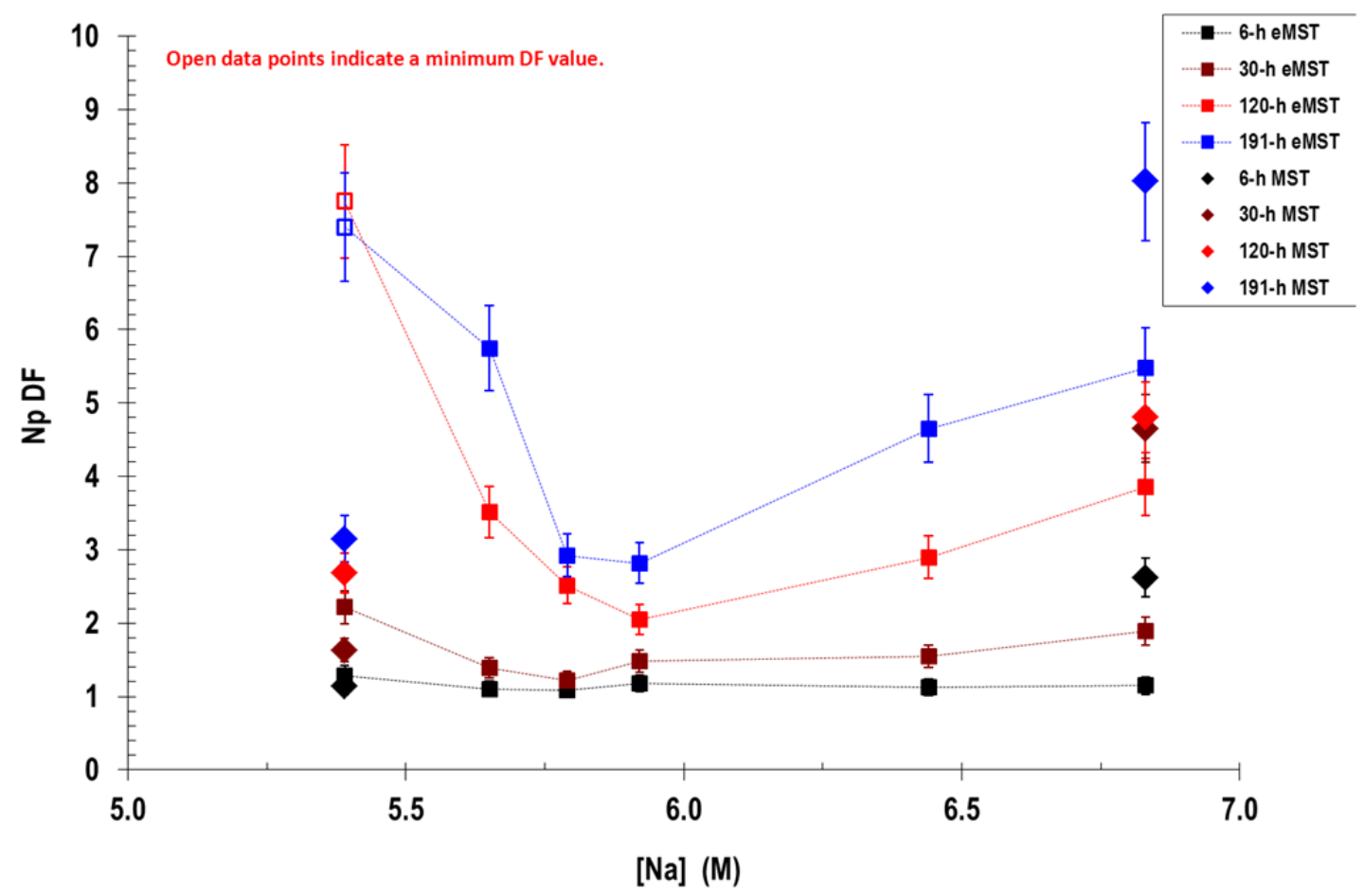

Figure 3-14. Np DF values versus Na concentration of the simulant for ${ }^{\mathrm{E}} \mathrm{MST}$ and MST.

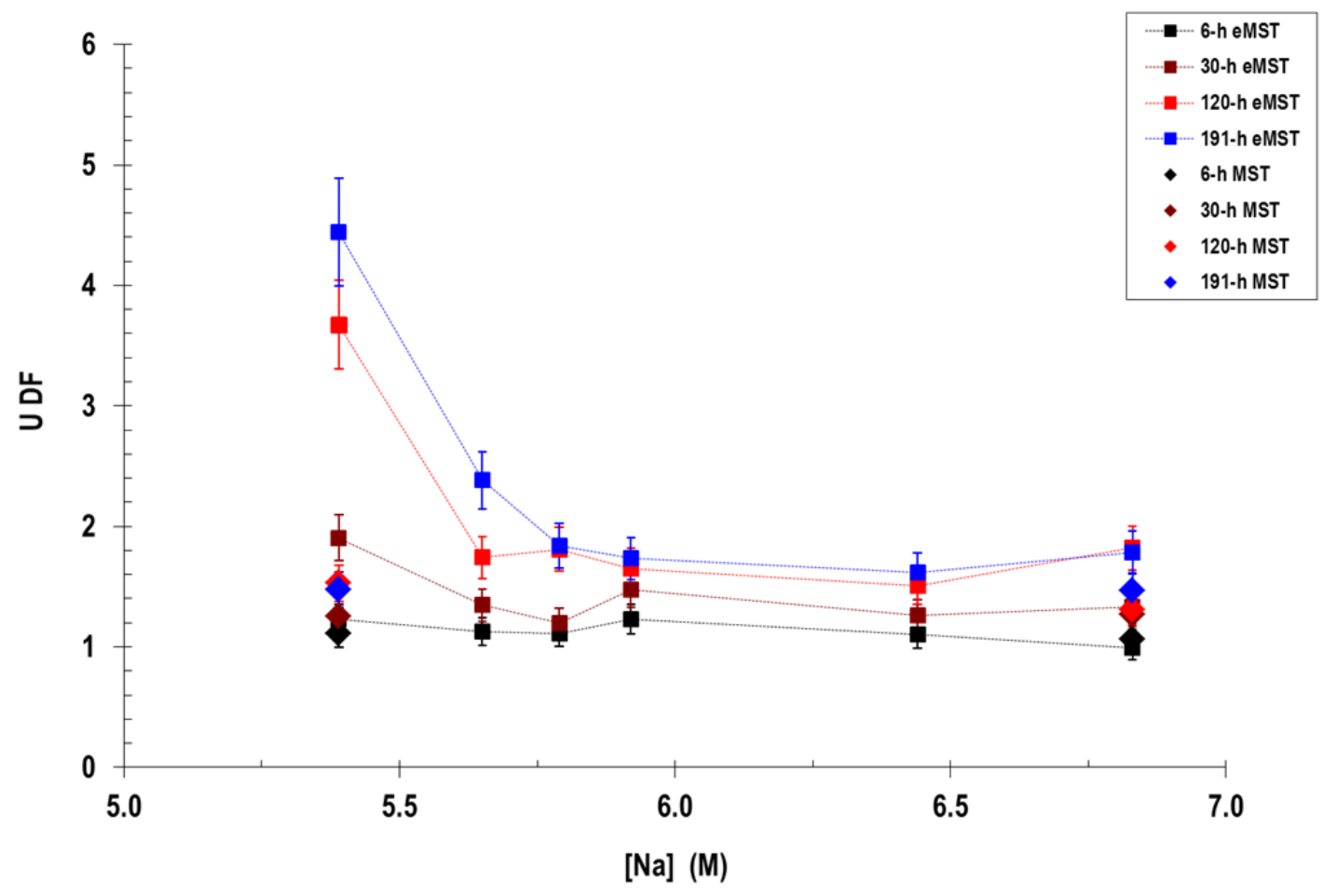

Figure 3-15. U DF values versus Na concentration of the simulant for ${ }^{\mathrm{E}} \mathrm{MST}$ and MST. 


\subsection{Sr Loading Isotherm}

A series of experiments were performed to examine the Sr loading isotherm of samples of the 2003 ORNL prepared ${ }^{\mathrm{E}}$ MST at various phase ratios. Samples of the ${ }^{\mathrm{E}}$ MST were contacted with a non-radioactive simulated salt solution containing $5.5 \mathrm{mg} / \mathrm{L}$ of $\mathrm{Sr}$ at liquid:solid phase ratios of $20000,5000,2500$, and $1250 \mathrm{~mL} / \mathrm{g}$. The $\mathrm{Sr}$ loading results (on a per gram of MST basis) are shown in Figure 3-16. The 2500 and 1250 phase ratio samples were only sampled once, at the 504 hour time point. The 20000 and $5000 \mathrm{~mL} / \mathrm{g}$ experiments were performed in duplicate. The $1250 \mathrm{~mL} / \mathrm{g}$ phase ratio represents the typical concentration of MST used in sorption testing and in the Actinide Removal Process (ARP), $0.4 \mathrm{~g} / \mathrm{L}$ ( $0.8 \mathrm{~g} / \mathrm{L}$ of $50 \mathrm{wt} \% \mathrm{MST}$ ).

The two lowest phase ratio experiments, 1250 and $2500 \mathrm{~mL} / \mathrm{g}$, reached $\mathrm{Sr}$ loadings of 1.34 and 2.64 wt \% after 506 hours of contact based on the mass of MST using the reported $50 \mathrm{wt} \%$ loading of MST in this lot of ${ }^{\mathrm{E}} \mathrm{MST}$. The duplicate experiments at $5000 \mathrm{~mL} / \mathrm{g}$ appeared to reach their maximum loadings after 506 hours, as no additional Sr sorption was seen at the later time point of 2402 hours. These experiments reached Sr loadings of 4.93 and 4.86 wt \% after 506 hours on a per gram of MST basis. The highest phase ratio experiments continued to sorb additional Sr over the entire test period, reaching maximum $\mathrm{Sr}$ loadings of 13.2 and $12.2 \mathrm{wt} \%$ after 2402 hours, again based on the mass of MST. These values show an increase in $\mathrm{wt} \% \mathrm{Sr}$ loaded of 4.69 and $3.11 \mathrm{wt} \%$ over the values at 506 hours, respectively.

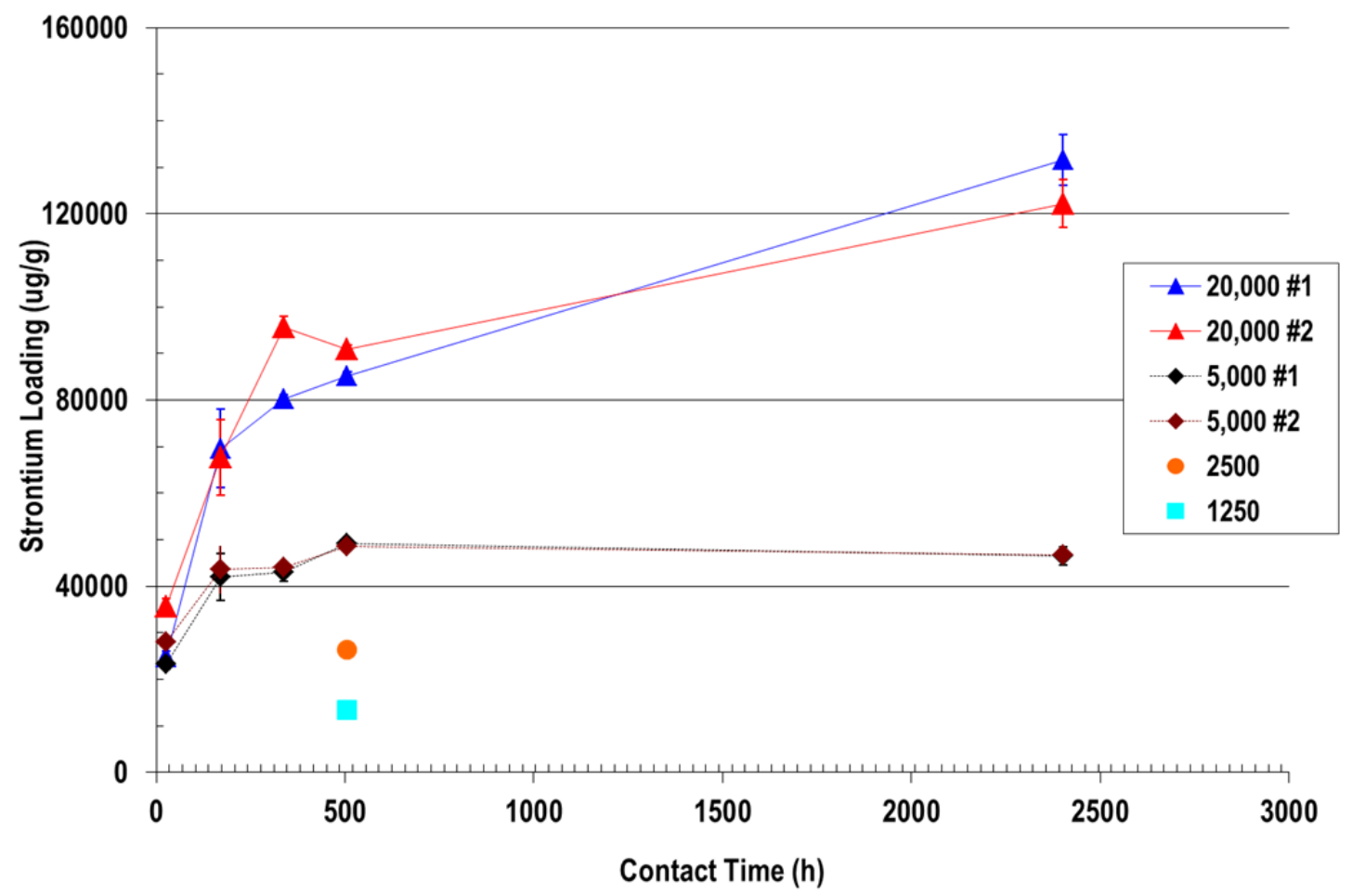

Figure 3-16. Sr loading isotherms for ${ }^{\mathrm{E}}$ MST (per $\mathrm{g}$ of MST basis) at various liquid:solid phase ratios. Phase ratios given in units of $\mathrm{mL} / \mathrm{g}$.

\subsection{Batch Contact Testing with Simulant}

A series of batch contact tests were performed using simulated waste solution (SWS-5-2009) to examine the performance of the 2010 ORNL prepared ${ }^{\mathrm{E}} \mathrm{MST}$ and ${ }^{\mathrm{E}} \mathrm{mMST}$ samples. The performance of these materials was compared to the non-engineered forms of MST and mMST. 
The procedure used is described in Section 2.3 (Tests ET $24-33$ ). In all tests MST and ${ }^{\mathrm{E}} \mathrm{MST}$ were added at an equivalent MST concentration of $0.4 \mathrm{~g} / \mathrm{L}$. The modified samples, mMST and ${ }_{\mathrm{E}}^{\mathrm{E}} \mathrm{mMST}$, were also added at $0.4 \mathrm{~g} / \mathrm{L}$ for Tests ET $24-28$, but were only added at concentrations of $0.1 \mathrm{~g} / \mathrm{L}$ for Tests ET 29-33.

A summary of the DFs obtained is provided in Table 3-4. Plots of sorbate concentration versus time and DF versus time are provided in Appendix A (Figures A-1 - A-8). Comparison of the results from Tests ET-25 and ET-30 and from Tests ET-26 and ET-32 showed that the performance of MST and ${ }^{\mathrm{E}} \mathrm{MST}$ is consistent over the two sets of test data where the MST and ${ }^{\mathrm{E}}$ MST were added at the same concentrations for both sets of tests. This data also shows that the MST outperforms the ${ }^{\mathrm{E}} \mathrm{MST}$ for $\mathrm{Sr}$ and Pu removal at these time scales. This is likely a kinetic effect due to the slower mass transfer in the larger engineered particles.

The Np and U removal was similar for the MST and ${ }^{\mathrm{E}}$ MST. Similar effects are seen when comparing the results from Tests ET-27 and ET-28 and the results from Tests ET-31 and ET-33. In both of these sets of data the non-engineered mMST greatly outperforms the ${ }^{\mathrm{E}} \mathrm{mMST}$ for $\mathrm{Sr}$ and $\mathrm{Pu}$ removal when added at the same equivalent mMST concentration. Again, this is likely due to kinetic effects from the slower mass transfer in the larger particles. There was not a large difference in $\mathrm{Np}$ and $\mathrm{U}$ removal when comparing the mMST and ${ }^{\mathrm{E}} \mathrm{mMST}$.

Comparison of the results from Tests ET-26 and 32 with the results from Test ET-28, showed that the performance of ${ }^{\mathrm{E}} \mathrm{MST}$ and ${ }^{\mathrm{E}} \mathrm{mMST}$ was similar, indicating the improved performance normally seen for mMST over MST was lost in the engineered forms of the material. It was hypothesized that this loss in performance for the ${ }^{\mathrm{E}} \mathrm{mMST}$ was due to the loss of the peroxide functionality during the internal gelation process used to produce the engineered materials. This hypothesis was somewhat confirmed by iodometric titrations, which showed that although the ${ }^{\mathrm{E}}$ mMST contained more peroxide than the ${ }^{\mathrm{E}} \mathrm{MST}$, the $\mathrm{H}_{2} \mathrm{O}_{2}$ :Ti ratio was less than $10 \%$ of the value for a freshly prepared batch of mMST (Table 3-3). Based on these results, attempts were made to restore the improved performance by treating samples of the ${ }^{\mathrm{E}} \mathrm{MST}$ and ${ }^{\mathrm{E}} \mathrm{mMST}$ with peroxide to increase the peroxide content (See Section 2.1 for procedure).

Iodometric titration of the post-peroxide-treated materials showed a slight increase in the peroxide content of the materials. The peroxide content of the $\mathrm{H}_{2} \mathrm{O}_{2}$ treated ${ }^{\mathrm{E}} \mathrm{MST}$ was still lower than that of the ${ }^{\mathrm{E}} \mathrm{mMST}$. The post peroxide treatment increased the peroxide content of the ${ }^{\mathrm{E}}$ mMST by approximately $10 \%$ (See Table 3-3). Batch contact testing was then performed using these peroxide-treated materials to determine if the performance had been improved. A summary of the DFs obtained with the peroxide-treated materials is provided in Table 3-5, compared to the materials before peroxide treatment.

Comparing the results from tests ET-32 and ET-36 show increased removal of $\mathrm{Sr}, \mathrm{Pu}$, and $\mathrm{Np}$ by the peroxide treated ${ }^{\mathrm{E}} \mathrm{MST}$ compared to the ${ }^{\mathrm{E}} \mathrm{MST}$ even at one quarter of the concentration (168 $\mathrm{h}$ results). Comparison of the results from Tests ET-33 and ET-37 show a similar trend, where the peroxide-treated ${ }^{\mathrm{E}} \mathrm{mMST}$ outperforms the as-received ${ }^{\mathrm{E}} \mathrm{mMST}$. The results from the 24 hour sample from ET-37 indicated an error in the sampling; therefore these results should be disregarded. Comparison of two peroxide-treated materials (ET-36 and ET-37) shows that the peroxide-treated ${ }^{\mathrm{E}} \mathrm{mMST}$ slightly outperforms the peroxide-treated ${ }^{\mathrm{E}} \mathrm{MST}$. This is consistent with the slightly higher peroxide content measured in the peroxide-treated ${ }^{\mathrm{E}} \mathrm{mMST}$. 
Table 3-4. Summary of DFs for Batch Contact Testing with Simulant.

\begin{tabular}{|c|c|c|c|c|c|c|c|c|}
\hline & \multicolumn{8}{|c|}{${ }^{85}$ Sr DF (Unc.) } \\
\hline Test ID & ET-25 & ET-30 & ET-26 & ET-32 & ET-27 & ET-31 & ET-28 & ET-33 \\
\hline Sorbent & MST & MST & ${ }^{\mathrm{E}} \mathbf{M S T}$ & ${ }^{\mathrm{E}} \mathrm{MST}$ & mMST & mMST & ${ }^{\mathrm{E}} \mathrm{mMST}$ & ${ }^{\mathrm{E}} \mathrm{mMST}$ \\
\hline Conc. (g/L) & 0.4 & 0.4 & 0.4 & 0.4 & 0.4 & 0.1 & 0.4 & 0.1 \\
\hline $4 \mathrm{~h}$ & $\begin{array}{c}53.7 \\
(5.37) \\
\end{array}$ & & $\begin{array}{c}1.46 \\
(0.146) \\
\end{array}$ & & $\begin{array}{c}273 \\
(31.5) \\
\end{array}$ & & $\begin{array}{c}2.20 \\
(0.220) \\
\end{array}$ & \\
\hline $6 \mathrm{~h}$ & & $\begin{array}{c}54.4 \\
(5.44) \\
\end{array}$ & & $\begin{array}{c}3.12 \\
(0.312) \\
\end{array}$ & & $\begin{array}{c}40.0 \\
(4.00) \\
\end{array}$ & & $\begin{array}{c}1.13 \\
(0.113) \\
\end{array}$ \\
\hline $24 \mathrm{~h}$ & $\begin{array}{c}68.6 \\
(6.86) \\
\end{array}$ & $\begin{array}{c}66.3 \\
(5.98)\end{array}$ & $\begin{array}{c}8.48 \\
(0.848) \\
\end{array}$ & $\begin{array}{c}6.46 \\
(0.583)\end{array}$ & $\begin{array}{c}435 \\
(43.5) \\
\end{array}$ & $\begin{array}{c}43.1 \\
(3.89)\end{array}$ & $\begin{array}{c}8.79 \\
(0.879) \\
\end{array}$ & $\begin{array}{c}1.22 \\
(0.110)\end{array}$ \\
\hline $48 \mathrm{~h}$ & & $\begin{array}{c}74.0 \\
(7.40)\end{array}$ & & $\begin{array}{c}5.45 \\
(0.545)\end{array}$ & & $\begin{array}{c}53.4 \\
(5.34)\end{array}$ & & $\begin{array}{c}1.46 \\
(0.146)\end{array}$ \\
\hline \multirow[t]{2}{*}{$168 \mathrm{~h}$} & & $\begin{array}{c}86.3 \\
(9.55) \\
\end{array}$ & & $\begin{array}{c}10.6 \\
(1.06) \\
\end{array}$ & & $\begin{array}{c}54.8 \\
(5.48) \\
\end{array}$ & & $\begin{array}{c}1.86 \\
(0.186) \\
\end{array}$ \\
\hline & \multicolumn{8}{|c|}{ Pu DF (Unc.) } \\
\hline Test ID & ET-25 & ET-30 & ET-26 & ET-32 & ET-27 & ET-31 & ET-28 & ET-33 \\
\hline Sorbent & MST & MST & ${ }^{\mathrm{E}} \mathrm{MST}$ & ${ }^{\mathrm{E}} \mathrm{MST}$ & mMST & mMST & ${ }^{\mathrm{E}} \mathrm{mMST}$ & ${ }^{\mathrm{E}} \mathrm{mMST}$ \\
\hline Conc. (g/L) & 0.4 & 0.4 & 0.4 & 0.4 & 0.4 & 0.1 & 0.4 & 0.1 \\
\hline $4 \mathrm{~h}$ & $\begin{array}{c}3.98 \\
(0.394) \\
\end{array}$ & & $\begin{array}{c}0.902 \\
(0.0930) \\
\end{array}$ & & $\begin{array}{c}185 \\
(26.7) \\
\end{array}$ & & $\begin{array}{c}1.43 \\
(0.149) \\
\end{array}$ & \\
\hline $6 \mathrm{~h}$ & & $\begin{array}{c}4.68 \\
(0.427) \\
\end{array}$ & & $\begin{array}{c}1.43 \\
(0.132) \\
\end{array}$ & & $\begin{array}{c}23.2 \\
(2.27) \\
\end{array}$ & & $\begin{array}{c}1.07 \\
(0.0961) \\
\end{array}$ \\
\hline $24 \mathrm{~h}$ & $\begin{array}{c}6.47 \\
(0.641)\end{array}$ & $\begin{array}{c}6.86 \\
(0.596)\end{array}$ & $\begin{array}{c}2.65 \\
(0.237)\end{array}$ & $\begin{array}{c}1.82 \\
(0.178)\end{array}$ & $751(146)$ & $\begin{array}{c}94.8 \\
(11.3)\end{array}$ & $\begin{array}{c}3.11 \\
(0.278)\end{array}$ & $\begin{array}{c}1.08 \\
(0.103)\end{array}$ \\
\hline $48 \mathrm{~h}$ & & $\begin{array}{c}9.66 \\
(1.01) \\
\end{array}$ & & $\begin{array}{c}1.87 \\
(0.204) \\
\end{array}$ & & $\begin{array}{c}152 \\
(22.6)\end{array}$ & & $\begin{array}{c}1.22 \\
(0.128) \\
\end{array}$ \\
\hline \multirow[t]{2}{*}{$168 \mathrm{~h}$} & & $\begin{array}{c}18.2 \\
(1.77) \\
\end{array}$ & & $\begin{array}{c}3.12 \\
(0.284) \\
\end{array}$ & & $\begin{array}{c}291 \\
(40.3) \\
\end{array}$ & & $\begin{array}{c}1.48 \\
(0.141) \\
\end{array}$ \\
\hline & \multicolumn{8}{|c|}{ NpDF (Unc.) } \\
\hline Test ID & ET-25 & ET-30 & ET-26 & ET-32 & ET-27 & ET-31 & ET-28 & ET-33 \\
\hline Sorbent & MST & MST & ${ }^{\mathrm{E}} \mathrm{MST}$ & ${ }^{\mathrm{E}} \mathbf{M S T}$ & mMST & mMST & ${ }^{\mathrm{E}} \mathrm{mMST}$ & ${ }^{\mathrm{E}} \mathrm{mMST}$ \\
\hline Conc. (g/L) & 0.4 & 0.4 & 0.4 & 0.4 & 0.4 & 0.1 & 0.4 & 0.1 \\
\hline $4 \mathrm{~h}$ & $\begin{array}{c}0.936 \\
(0.374) \\
\end{array}$ & & $\begin{array}{c}0.682 \\
(0.273) \\
\end{array}$ & & $\begin{array}{c}1.35 \\
(0.541) \\
\end{array}$ & & $\begin{array}{c}1.27 \\
(0.508) \\
\end{array}$ & \\
\hline $6 \mathrm{~h}$ & & $\begin{array}{c}1.54 \\
(0.615) \\
\end{array}$ & & $\begin{array}{c}1.73 \\
(0.692) \\
\end{array}$ & & $\begin{array}{c}1.73 \\
(0.692) \\
\end{array}$ & & $\begin{array}{c}1.10 \\
(0.442) \\
\end{array}$ \\
\hline $24 \mathrm{~h}$ & $\begin{array}{c}1.28 \\
(0.512) \\
\end{array}$ & $\begin{array}{c}1.38 \\
(0.550) \\
\end{array}$ & $\begin{array}{c}1.22 \\
(0.639) \\
\end{array}$ & $\begin{array}{c}1.20 \\
(0.478) \\
\end{array}$ & $\begin{array}{c}2.82 \\
(1.13) \\
\end{array}$ & $\begin{array}{c}1.20 \\
(0.508) \\
\end{array}$ & $\begin{array}{c}1.99 \\
(0.890) \\
\end{array}$ & $\begin{array}{c}1.01 \\
(0.405) \\
\end{array}$ \\
\hline $48 \mathrm{~h}$ & & $\begin{array}{c}2.40 \\
(0.961) \\
\end{array}$ & & $\begin{array}{c}2.04 \\
(0.817) \\
\end{array}$ & & $\begin{array}{c}1.27 \\
(0.509) \\
\end{array}$ & & $\begin{array}{c}0.944 \\
(0.378) \\
\end{array}$ \\
\hline \multirow[t]{2}{*}{$168 \mathrm{~h}$} & & $\begin{array}{c}2.33 \\
(0.933) \\
\end{array}$ & & $\begin{array}{c}2.04 \\
(0.817) \\
\end{array}$ & & $\begin{array}{c}1.62 \\
(0.647) \\
\end{array}$ & & $\begin{array}{c}1.27 \\
(0.509) \\
\end{array}$ \\
\hline & \multicolumn{8}{|c|}{ U DF (Unc.) } \\
\hline Test ID & ET-25 & ET-30 & ET-26 & ET-32 & ET-27 & ET-31 & ET-28 & ET-33 \\
\hline Sorbent & MST & MST & ${ }^{\mathrm{E}} \mathrm{MST}$ & ${ }^{\mathrm{E}} \mathbf{M S T}$ & mMST & mMST & ${ }^{\mathrm{E}} \mathrm{mMST}$ & ${ }^{{ }^{E}}$ mMST \\
\hline Conc. (g/L) & 0.4 & 0.4 & 0.4 & 0.4 & 0.4 & 0.1 & 0.4 & 0.1 \\
\hline $4 \mathrm{~h}$ & $\begin{array}{c}1.16 \\
(0.465) \\
\end{array}$ & & $\begin{array}{c}0.751 \\
(0.300) \\
\end{array}$ & & $\begin{array}{c}1.05 \\
(0.421) \\
\end{array}$ & & $\begin{array}{c}1.06 \\
(0.423) \\
\end{array}$ & \\
\hline $6 \mathrm{~h}$ & & $\begin{array}{c}1.12 \\
(0.447)\end{array}$ & & $\begin{array}{c}1.14 \\
(0.455)\end{array}$ & & $\begin{array}{c}1.09 \\
(0.436)\end{array}$ & & $\begin{array}{c}1.05 \\
(0.418)\end{array}$ \\
\hline $24 \mathrm{~h}$ & $\begin{array}{c}1.21 \\
(0.484)\end{array}$ & $\begin{array}{c}1.03 \\
(0.412)\end{array}$ & $\begin{array}{c}1.47 \\
(0.588) \\
\end{array}$ & $\begin{array}{c}1.26 \\
(0.502)\end{array}$ & $\begin{array}{c}1.05 \\
(0.419)\end{array}$ & $\begin{array}{c}0.899 \\
(0.360)\end{array}$ & $\begin{array}{c}1.06 \\
(0.424) \\
\end{array}$ & $\begin{array}{c}0.991 \\
(0.396)\end{array}$ \\
\hline $48 \mathrm{~h}$ & & $\begin{array}{c}1.27 \\
(0.510) \\
\end{array}$ & & $\begin{array}{c}1.24 \\
(0.497) \\
\end{array}$ & & $\begin{array}{c}0.989 \\
(0.395) \\
\end{array}$ & & $\begin{array}{c}0.864 \\
(0.346) \\
\end{array}$ \\
\hline $168 \mathrm{~h}$ & & $\begin{array}{c}1.35 \\
(0.541)\end{array}$ & & $\begin{array}{c}1.42 \\
(0.569)\end{array}$ & & $\begin{array}{c}1.01 \\
(0.402)\end{array}$ & & $\begin{array}{c}1.06 \\
(0.425)\end{array}$ \\
\hline
\end{tabular}


SRNL-STI-2012-00193

Revision 0

Table 3-5. Comparison of DFs for ${ }^{\mathrm{E}} \mathrm{MST}$ and ${ }^{\mathrm{E}} \mathrm{mMST}$ before and after peroxide treatment.

\begin{tabular}{|c|c|c|c|c|}
\hline Test ID & ET-32 & ET-36 & ET-33 & ET-37 \\
\hline Sorbent & ${ }^{\mathbf{E}}$ MST & $\mathrm{H}_{2} \mathrm{O}_{2}$ treated ${ }^{\mathrm{E}} \mathrm{MST}$ & ${ }^{\mathbf{E}_{\mathrm{mMST}}}$ & $\mathrm{H}_{2} \mathrm{O}_{2}$ treated ${ }^{\mathrm{E}} \mathrm{mMST}$ \\
\hline Conc. (g/L) & 0.4 & 0.1 & 0.1 & 0.1 \\
\hline $24 \mathrm{~h}^{85} \mathrm{Sr}$ DF (Unc.) & $6.46(0.646)$ & $2.51(0.251)$ & $1.22(0.122)$ & $>1936$ \\
\hline $168 \mathrm{~h}^{85} \mathrm{Sr}$ DF (Unc.) & $10.65(1.06)$ & $12.8(1.28)$ & $1.86(0.186)$ & $15.6(1.56)$ \\
\hline 24 h Pu DF (Unc.) & $1.82(0.178)$ & $1.89(0.197)$ & $1.08(0.103)$ & $>839^{\prime \prime}$ \\
\hline 168 h Pu DF (Unc.) & $3.12(0.284)$ & $10.4(0.943)$ & $1.48(0.141)$ & $23.3(2.35)$ \\
\hline 24 h Np DF (Unc.) & $1.27(0.510)$ & $1.18(0.472)$ & $1.01(0.410)$ & $>1.75^{\prime}$ \\
\hline 168 h Np DF (Unc.) & $1.62(0.650)$ & $>1.97$ & $1.27(0.510)$ & $>1.97$ \\
\hline 24 h U DF (Unc.) & $1.26(0.500)$ & $1.10(0.441)$ & $0.991(0.400)$ & $>31.6$ \\
\hline 168 h U DF (Unc.) & $1.42(0.570)$ & $1.10(0.440)$ & $1.06(0.430)$ & $1.01(0.406)$ \\
\hline
\end{tabular}

*Results indicated an error in sampling, these results should be disregarded.

\subsection{Batch Contact Testing with Real Waste}

A series of batch contact tests were also performed using a sample of Tank 49 supernate. The 2010 prepared ORNL ${ }^{\mathrm{E}}$ MST and ${ }^{\mathrm{E}} \mathrm{mMST}$ were contacted with the waste, along with samples of the non-engineered forms of MST and mMST. The MST and ${ }^{\mathrm{E}} \mathrm{MST}$ were added at a concentration of $0.4 \mathrm{~g} / \mathrm{L}$, while the mMST and ${ }^{\mathrm{E}}$ mMST were added at a concentration of $0.2 \mathrm{~g} / \mathrm{L}$.

A summary of the DFs is provided in Table 3-6 and plots of sorbate concentration and DF versus time are provided in Appendix A (Figures A-9 - A-16). Overall, mMST showed the greatest $\mathrm{Sr}$ and $\mathrm{Pu}$ removal performance, while MST showed greater removal of $\mathrm{Np}$ and $\mathrm{U}$. The engineered materials did not perform as well as the non-engineered materials, and this is likely due to the slower mass transfer as a result of the larger particle size of the engineered forms. When only comparing the engineered forms, there did not appear to be an increase in performance of the modified material compared to the baseline engineered MST. As discussed above, it is possible that the peroxide functionality of the mMST was decomposed during the internal gelation process used to produce the engineered materials. 
Table 3-6. Summary of DF values from real waste testing. (Number in parentheses represents 1 sigma uncertainty).

\begin{tabular}{|c|c|c|c|c|}
\hline \multirow{2}{*}{ Time } & \multicolumn{4}{|c|}{${ }^{90} \mathrm{Sr}$ DF (Unc.) } \\
\hline & MST & mMST & ${ }^{\mathbf{E}} \mathbf{M S T}$ & ${ }^{\mathrm{E}} \mathrm{mMST}$ \\
\hline 2-h & $33.3(3.98)$ & $27.9(3.43)$ & $1.04(0.132)$ & $1.02(0.127)$ \\
\hline 6-h & $43.8(5.01)$ & $41.2(4.92)$ & $1.26(0.147)$ & $1.02(0.117)$ \\
\hline 12-h & $60.2(7.30)$ & $64.2(7.87)$ & $2.05(0.242)$ & $1.36(0.168)$ \\
\hline 24-h & $58.2(7.07)$ & $92.6(10.9)$ & $2.38(0.286)$ & $1.44(0.176)$ \\
\hline \multirow{2}{*}{ Time } & \multicolumn{4}{|c|}{ Pu DF (Unc.) } \\
\hline & MST & mMST & ${ }^{\mathrm{E}} \mathrm{MST}$ & ${ }^{\mathrm{E}} \mathbf{m M S T}$ \\
\hline 2-h & $1.65(0.108)$ & $1.64(0.112)$ & $1.04(0.0691)$ & $1.07(0.0673)$ \\
\hline 6-h & $1.86(0.123)$ & $2.12(0.146)$ & $1.11(0.0761)$ & $0.973(0.0669)$ \\
\hline 12-h & $2.19(0.149)$ & $3.49(0.239)$ & $1.25(0.0888)$ & $1.01(0.0732)$ \\
\hline 24-h & $2.19(0.157)$ & $4.45(0.305)$ & $1.19(0.0866)$ & $1.08(0.0779)$ \\
\hline \multirow{2}{*}{ Time } & \multicolumn{4}{|c|}{ Np DF (Unc.) } \\
\hline & MST & mMST & ${ }^{\mathrm{E}} \mathrm{MST}$ & ${ }^{\mathrm{E}_{\mathrm{mMST}}}$ \\
\hline 2-h & $1.20(0.434)$ & $1.28(0.456)$ & $1.10(0.357)$ & $1.08(0.304)$ \\
\hline 6-h & $1.39(0.403)$ & $0.932(0.270)$ & $1.21(0.351)$ & $0.912(0.264)$ \\
\hline 12-h & $>1.83$ & $1.24(0.351)$ & $1.58(0.448)$ & $1.49(0.421)$ \\
\hline 24-h & $>1.49$ & $1.25(0.621)$ & $0.945(0.267)$ & $0.961(0.272)$ \\
\hline \multirow{2}{*}{ Time } & \multicolumn{4}{|c|}{ U DF (Unc.) } \\
\hline & MST & mMST & ${ }^{\mathrm{E}}$ MST & ${ }^{\mathrm{E}_{\mathrm{mMST}}}$ \\
\hline 2-h & $1.11(0.314)$ & $1.07(0.302)$ & $1.10(0.312)$ & $1.06(0.300)$ \\
\hline 6-h & $1.08(0.306)$ & $1.03(0.291)$ & $1.05(0.297)$ & $1.01(0.285)$ \\
\hline 12-h & $1.10(0.310)$ & $1.02(0.289)$ & $1.11(0.313)$ & $1.02(0.289)$ \\
\hline 24-h & $1.10(0.311)$ & $0.987(0.279)$ & $1.12(0.315)$ & $1.01(0.287)$ \\
\hline
\end{tabular}

\subsection{Column Testing}

Two ion-exchange columns were used, one with the 2010 ORNL prepared ${ }^{\mathrm{E}} \mathrm{MST}$ and the other with the peroxide treated ${ }^{\mathrm{E}}$ mMST material. Approximately $1.8 \mathrm{~g}$ of each material was pre-soaked in a salt solution, and then loaded into the columns. Each column processed $\sim 15 \mathrm{~L}$ of simulated waste solution at a flow rate of $\sim 0.5 \mathrm{~mL} / \mathrm{min}$, and samples of the effluent were collected throughout the experiment. During the soaking, the ${ }^{\mathrm{E}} \mathrm{MST}$ material was found to swell dramatically $(\sim 114 \%)$ compared to the peroxide treated ${ }^{\mathrm{E}} \mathrm{mMST}$, which only swelled $\sim 23 \%$. Photos of the columns are provided in Figures 3-17 and 3-18. Additional swelling studies showed that both the ${ }^{\mathrm{E}} \mathrm{MST}$ and ${ }^{\mathrm{E}} \mathrm{mMST}$ swell upon contact with salt solution, whereas neither of the peroxide treated materials swelled significantly. 


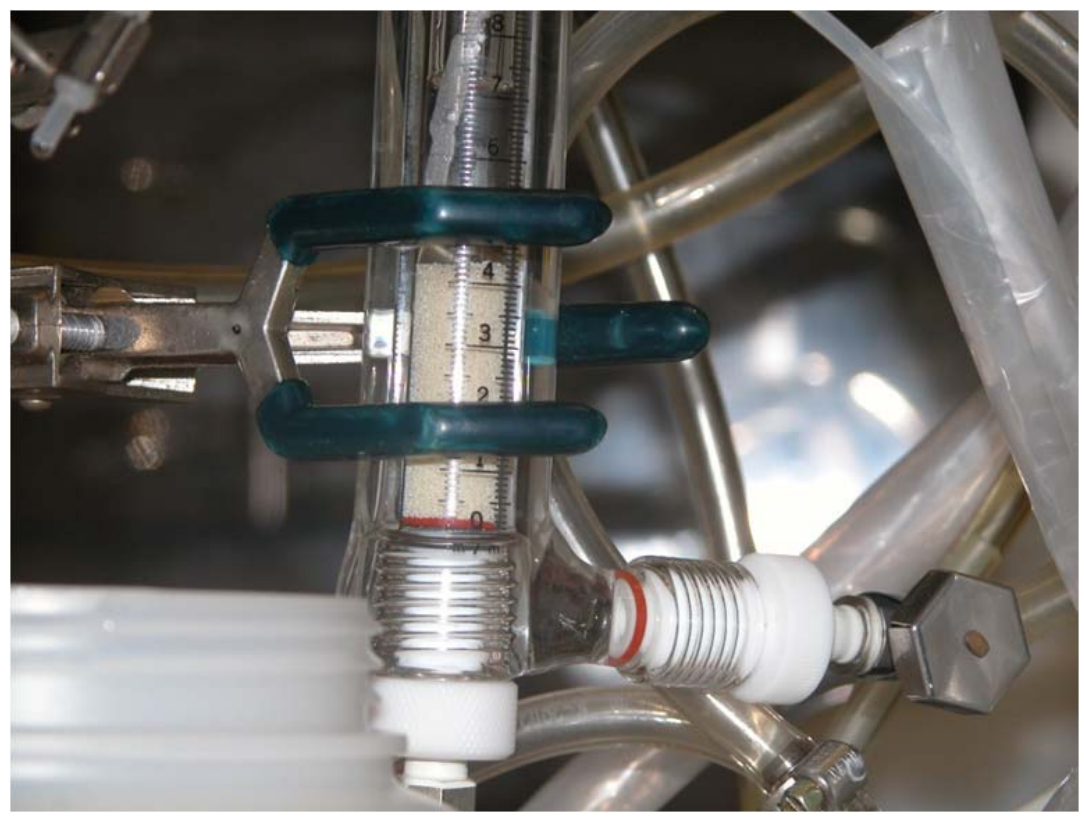

Figure 3-17. Photo of ${ }^{\mathrm{E}}$ MST Column.

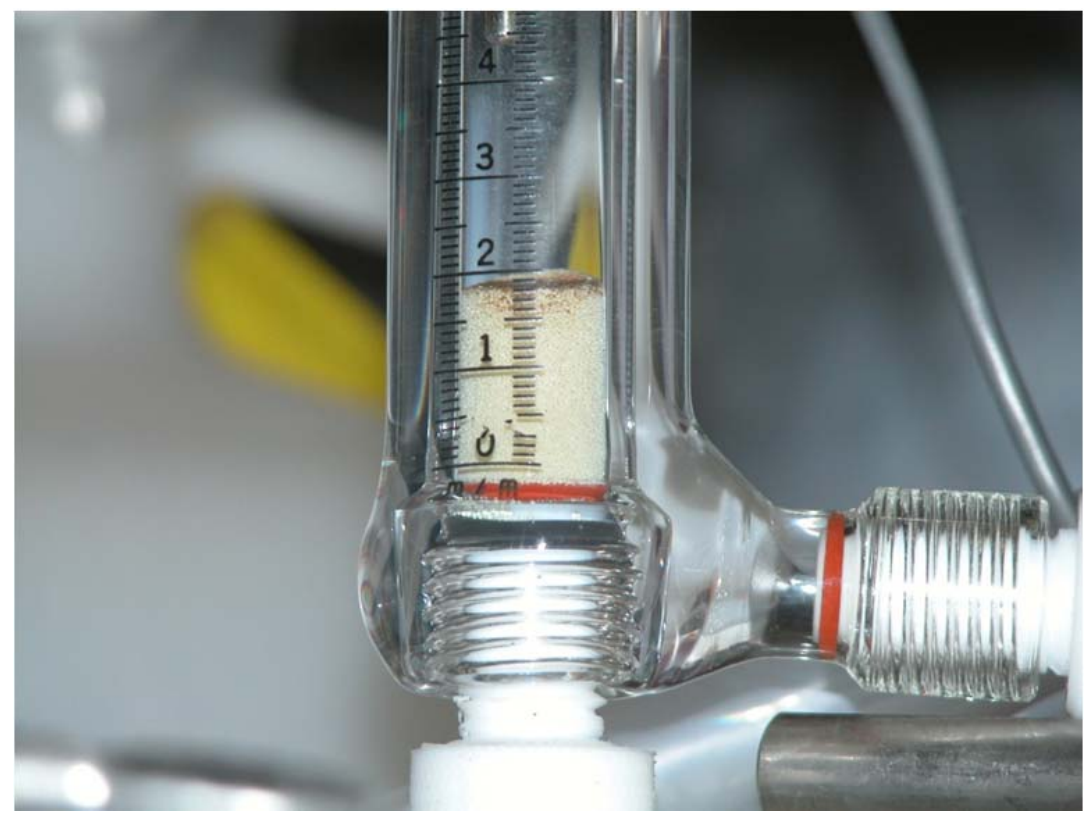

Figure 3-18. Photo of Peroxide Treated ${ }^{\mathrm{E}} \mathrm{mMST}$ Column.

A summary of the flow rates and samples collected is provided in Appendix B. Column 1 ( ${ }^{\mathrm{E}} \mathrm{MST}$ ) processed a total of 3578 bed volumes, while Column 2 (peroxide treated ${ }^{\mathrm{E}} \mathrm{mMST}$ ) processed a total of 6934 bed volumes. The large difference in the number of bed volumes processed is due to the variable amounts of swelling. The bed volume of Column 1 was much greater than that of Column 2, due to the increased swelling of the ${ }^{\mathrm{E}} \mathrm{MST}$ material. For Column 1, a sample was analyzed about every 500 bed volumes, and for Column 2, a sample was analyzed about every 1000 bed volumes. Note that both tests used the same mass quantity of ion exchanger. 
The breakthrough curves for ${ }^{85} \mathrm{Sr}$ are shown in Figure 3-19. This data shows that the peroxide treated ${ }^{\mathrm{E}} \mathrm{mMST}$ out-performs the ${ }^{\mathrm{E}} \mathrm{MST}$ on a bed volume basis. Although $50 \%$ breakthrough was not reached for ${ }^{85} \mathrm{Sr}$, the curves indicate that a larger number of bed volumes can be processed through the peroxide treated ${ }^{\mathrm{E}} \mathrm{mMST}$ column before reaching $50 \%$ breakthrough, indicating a higher capacity. The breakthrough curve for the ${ }^{\mathrm{E}} \mathrm{MST}$ is sharper, and this is likely due to the swollen bed, which reduces the bed volumes per hour rate to about half of the other column.

The breakthrough curves for Pu are shown in Figure 3-20. Unlike the ${ }^{85} \mathrm{Sr}$ curves, which started near $0 \%$ breakthrough, these curves show $\sim 20 \%$ breakthrough after only about 1000 bed volumes. At the end of the tests breakthroughs of $\sim 50-60 \%$ were reached for both columns. From this data and from analysis of the sorbent beds (see below) there does not appear to be a large difference in $\mathrm{Pu}$ capacity between the two materials.

Figure 3-21 shows the $\mathrm{Np}$ breakthrough curves for both columns. Again, similarly to the $\mathrm{Pu}$ curves, there is a significant amount of breakthrough early in the test, and the peroxide treated ${ }^{\mathrm{E}} \mathrm{mMST}$ actually reaches $100 \%$ breakthrough before the end of the column test. There does not appear to be a large difference in the capacities of the two materials, estimated by the number of bed volumes passed when $50 \%$ breakthrough is reached. The $\mathrm{U}$ breakthrough curves are shown in Figure 3-22. Both columns reached $100 \%$ breakthrough prior to the end of the column experiment.

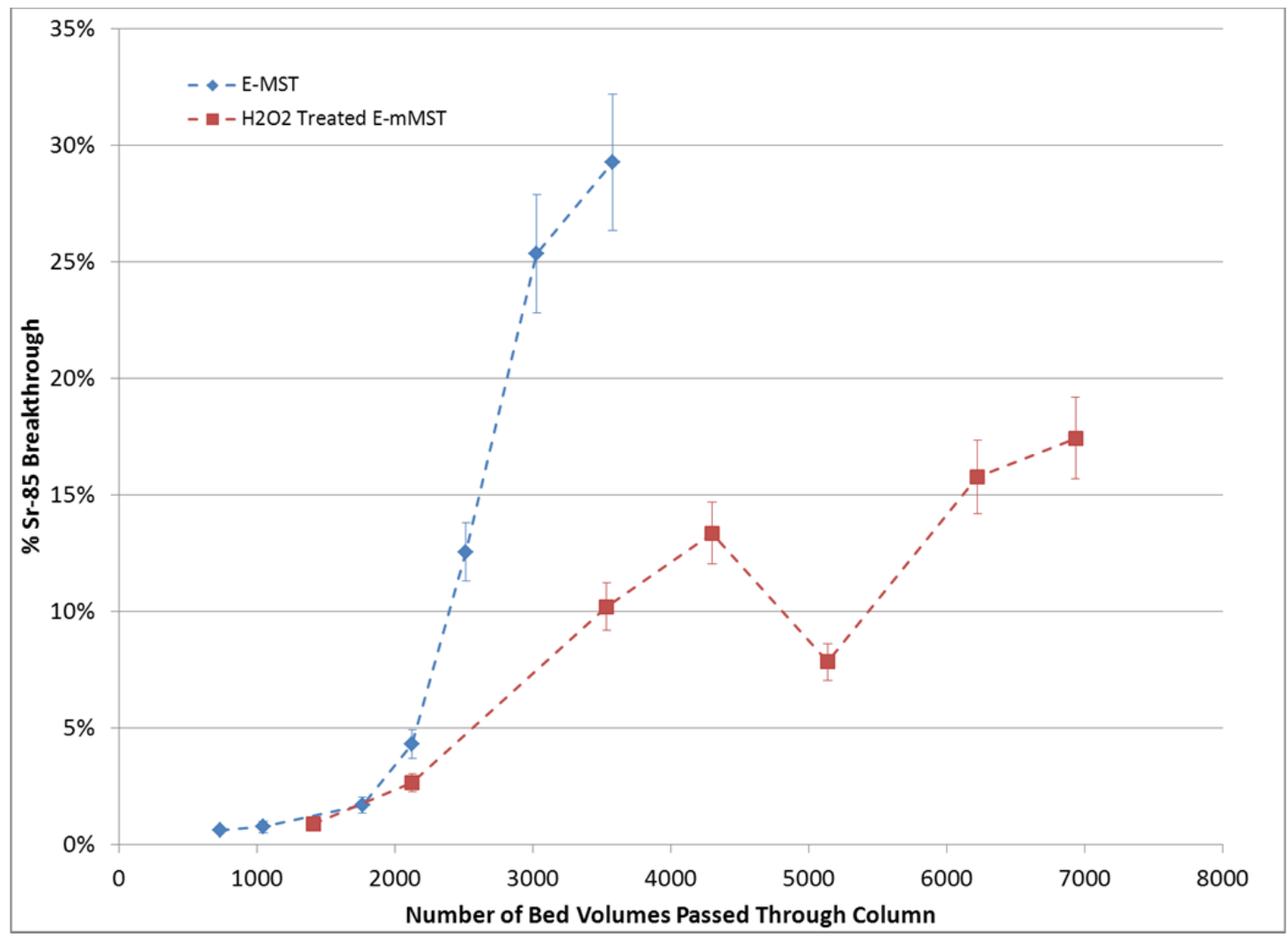

Figure 3-19. ${ }^{85} \mathrm{Sr}$ breakthrough curves for the ${ }^{\mathrm{E}} \mathrm{MST}$ and peroxide treated ${ }^{\mathrm{E}} \mathrm{mMST}$ columns. 
SRNL-STI-2012-00193

Revision 0

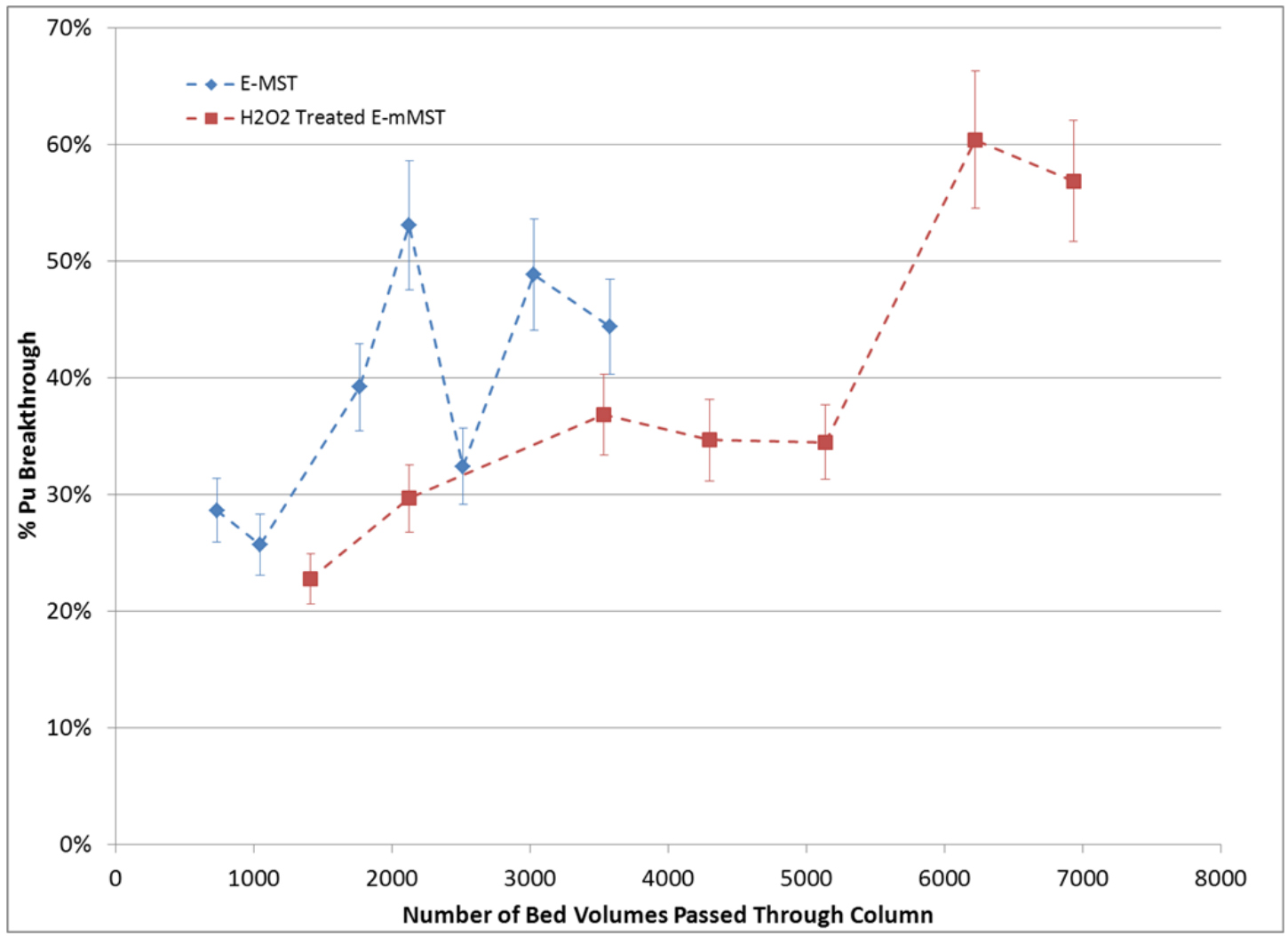

Figure 3-20. Pu breakthrough curves for the ${ }^{\mathrm{E}} \mathrm{MST}$ and peroxide treated ${ }^{\mathrm{E}} \mathrm{mMST}$ columns.

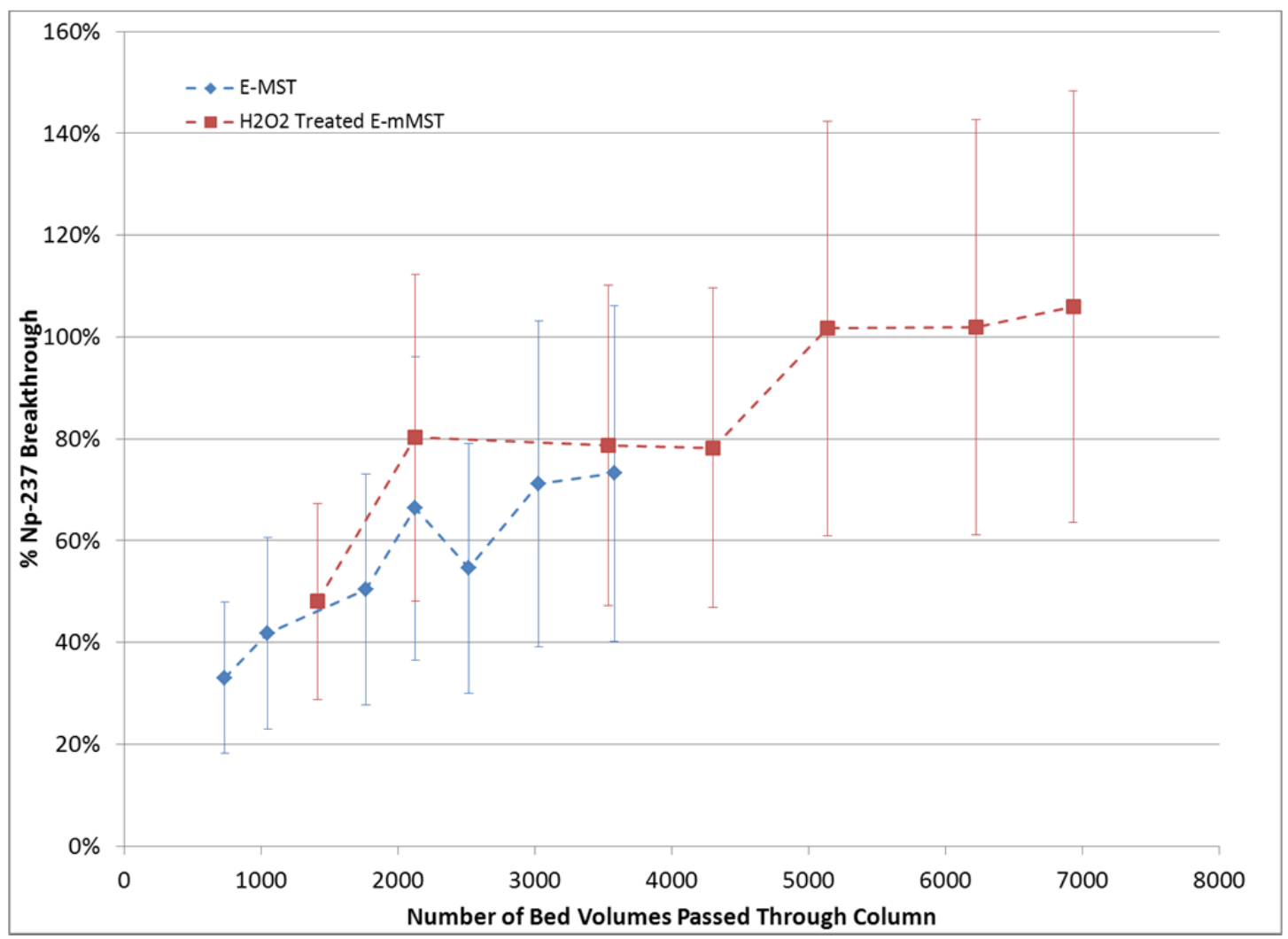

Figure 3-21. Np breakthrough curves for the ${ }^{\mathrm{E}} \mathrm{MST}$ and peroxide treated ${ }^{\mathrm{E}} \mathrm{mMST}$ columns. 


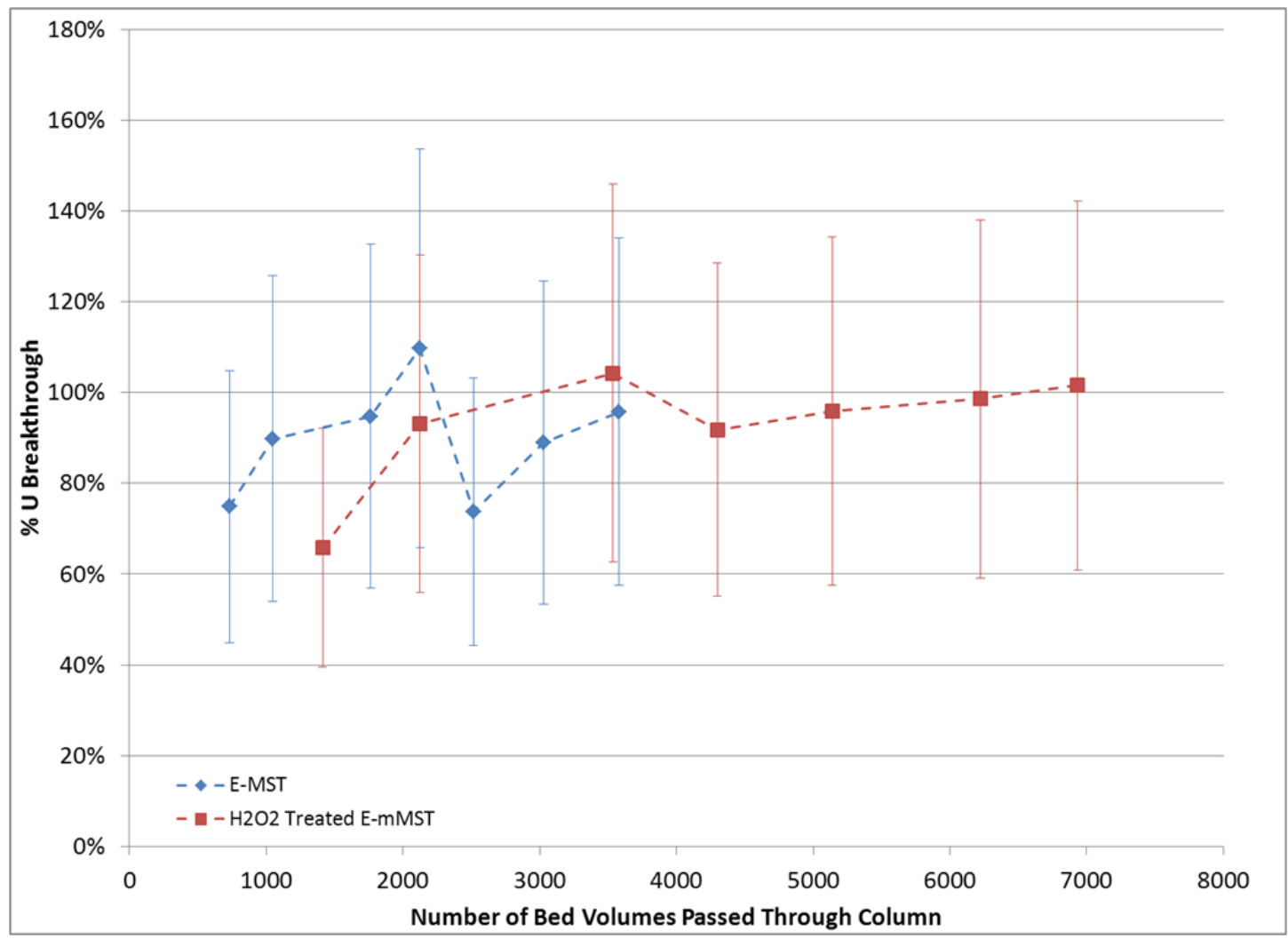

Figure 3-22. U breakthrough curves for the ${ }^{\mathrm{E}} \mathrm{MST}$ and peroxide treated ${ }^{\mathrm{E}} \mathrm{mMST}$ columns.

In addition to analyzing samples of the effluent collected throughout the test, at the end of the experiment, samples of the bed materials were digested and analyzed for sorbate concentrations. Table 3-7 provides a summary of the sobent loadings determined from these measurements. As can be seen from the data, the peroxide treated ${ }^{\mathrm{E}}$ mMST sorbed a higher percentage of each sorbate than the ${ }^{\mathrm{E}} \mathrm{MST}$, with the exception of $\mathrm{U}$ and $\mathrm{Pu}$. The $\mathrm{Pu}$ uptake by both materials was similar, $57.9 \%$ and $58.1 \%$, for ${ }^{\mathrm{E}} \mathrm{MST}$ and peroxide treated ${ }^{\mathrm{E}} \mathrm{mMST}$, respectively.

Table 3-7. Sorbate loadings on ${ }^{\mathrm{E}} \mathrm{MST}$ and peroxide treated ${ }^{\mathrm{E}} \mathrm{mMST}$ at the end of the column runs. The values in parenthesis indicate the percentage of the feed that was sorbed.

\begin{tabular}{|c|c|c|}
\hline & $\overline{{ }^{E} \text { MST }}$ & $\overline{\mathrm{H}_{2} \mathrm{O}_{2} \text { Treated }{ }^{\mathrm{E}} \mathrm{mMST}}$ \\
\hline 㒸5r (dpm/g) (gamma) & $3.38 \mathrm{E}+07 \pm 1.69 \mathrm{E}+06(54.4 \%)$ & $3.81 \mathrm{E}+07 \pm 1.91 \mathrm{E}+06(74.0 \%)$ \\
\hline Total Sr $(\mu \mathrm{g} / \mathrm{g})(\mathrm{ICP}-\mathrm{MS})$ & $2,880 \pm 579(62.1 \%)$ & $3,600 \pm 719(73.7 \%)$ \\
\hline${ }^{237} \mathrm{~Np}(\mu \mathrm{g} / \mathrm{g})$ (gamma) & $1,170 \pm 58.6(28.0 \%)$ & $1,260 \pm 63.0(34.6 \%)$ \\
\hline${ }^{237} \mathrm{~Np}(\mu \mathrm{g} / \mathrm{g})(\mathrm{ICP}-\mathrm{MS})$ & $1,060 \pm 212(22.9 \%)$ & $1,190 \pm 238(36.0 \%)$ \\
\hline${ }^{137} \mathrm{Cs}$ (dpm/g) (gamma) & $54,500 \pm 2,730(0.02 \%)$ & $233,000 \pm 11,600(0.08 \%)$ \\
\hline Cs $(\mu \mathrm{g} / \mathrm{g})(\mathrm{ICP}-\mathrm{MS})$ & $39.3 \pm 7.85(0.03 \%)$ & $118 \pm 23.6(0.09 \%)$ \\
\hline Pu $(\mu \mathrm{g} / \mathrm{g})($ PuTTA) & $715 \pm 35.4(57.9 \%)$ & $769 \pm 38.4(58.1 \%)$ \\
\hline $\mathrm{U}(\mu \mathrm{g} / \mathrm{g})(\mathrm{ICP}-\mathrm{MS})$ & $3,470 \pm 693(9.83 \%)$ & $1,900 \pm 379(5.73 \%)$ \\
\hline
\end{tabular}

\subsection{Conclusions}

Bench scale quantities of ${ }^{\mathrm{E}} \mathrm{MST}$ and ${ }^{\mathrm{E}} \mathrm{mMST}$ were successfully prepared at ORNL using an internal gelation process. Characterization of these materials showed that they are generally spherical with some irregular shaped particles, and have an average diameter of $450-550 \mu \mathrm{m}$. The majority of the particles were found to be in the range of $200-800 \mu \mathrm{m}$. Iodometric titration was used to determine the peroxide content of the materials, and the ${ }^{\mathrm{E}} \mathrm{mMST}$ was found to 
contain less than $10 \%$ of the peroxide found in a freshly prepared batch of mMST. This was also evidenced in batch contact testing with both simulated and actual waste, where little difference in performance was seen between the two engineered materials, ${ }^{\mathrm{E}} \mathrm{MST}$ and ${ }^{\mathrm{E}} \mathrm{mMST}$.

Based on these results, attempts were made to increase the peroxide content of the materials by post-treatment with hydrogen peroxide. The peroxide treatment resulted in a slight $(\sim 10 \%)$ increase in peroxide content, however the peroxide:Ti molar ratio was still much lower $(\sim 0.1 \mathrm{X})$ than what is seen in a freshly prepared batch of mMST. Performance testing with simulated waste showed the performance of the peroxide treated materials was improved.

A series of batch contact tests were also performed with an earlier (2003) prepared lot of ${ }^{\mathrm{E}} \mathrm{MST}$ to examine the effect of ionic strength on the performance of the material. In general the results showed a decrease in removal performance with increasing ionic strength, which is consistent with previous ionic strength testing with MST. For $\mathrm{Sr}, \mathrm{Pu}$, and $\mathrm{U}$, the most drastic decrease in DF was observed upon increasing the Na concentration from 5.39 to $5.65 \mathrm{M}$, with less of an effect over the remaining $\mathrm{Na}$ concentration range (up to $6.83 \mathrm{M}$ ). For $\mathrm{Np}$, the performance was also found to decrease upon increasing $\mathrm{Na}$ concentration up to $5.92 \mathrm{M}$, after which the DF appeared to rise with increasing ionic strength. For the non-engineered MST, the Np DF was found to increase when the $\mathrm{Na}$ concentration was increased from 5.39 to $6.83 \mathrm{M}$.

Results from the Sr loading isotherm testing showed that the ${ }^{\mathrm{E}} \mathrm{MST}$ material can reach a $\mathrm{Sr}$ loading as high as $13.2 \mathrm{wt} \%$ after 100 days of contact at a phase ratio of $20000 \mathrm{~mL} / \mathrm{g}$. At the typical MST phase ratio of $2500 \mathrm{~mL} / \mathrm{g}(0.4 \mathrm{~g} / \mathrm{L})$, a Sr loading of $2.64 \mathrm{wt} \%$ was reached after 506 hours of contact.

Samples of ${ }^{\mathrm{E}} \mathrm{MST}$ and peroxide-treated ${ }^{\mathrm{E}} \mathrm{mMST}$ were also tested in a column configuration using simulated waste solution. Each column processed a total of approximately $15 \mathrm{~L}$ of simulated waste over a period of approximately 3 weeks. The ${ }^{\mathrm{E}} \mathrm{MST}$ material was found to swell dramatically $(\sim 114 \%)$ compared to the peroxide treated ${ }^{\mathrm{E}} \mathrm{mMST}$, which swelled only slightly $(\sim 23 \%)$. This difference in swelling resulted in a difference in the total number of bed volumes processed, even though similar volumes were processed. The breakthrough curves along with analysis of the sorbent beds at the conclusion of the experiments showed that the peroxide treated ${ }^{\mathrm{E}} \mathrm{mMST}$ has a higher $\mathrm{Sr}$ and $\mathrm{Np}$ capacity, but that both materials have similar Pu capacities. The ${ }^{\mathrm{E}}$ MST removed a larger percentage of $\mathrm{U}$ than the peroxide-treated ${ }^{\mathrm{E}} \mathrm{mMST}$, which is consistent with previous testing which showed that mMST has little affinity for U under these conditions.

\subsection{Recommendations}

We recommend additional testing be performed to optimize the material. Additional experiments should be performed to determine the optimal conditions for the internal gelation process forming the particles, particularly optimizing conditions affecting the porosity of the particles to provide the best possible mass transport. Additional experiments should also be performed to optimize the post-peroxide treatment of the material to increase the peroxide content. Optimization of both of these processes will result in increased performance of the material for strontium and actinide separations. 


\subsection{References}

1. C. A. Nash, D. T. Hobbs, K. Adu-Wusu, and E. C. Buck, "Phase I Technical Report for the Engineering of Monosodium Titanate." WSRC-TR-2004-00286, Rev. 0, July 30, 2004.

2. D. T. Hobbs, M. J. Barnes, R. L. Pulmano, K. M. Marshall, T. B. Edwards, M. G. Bronikowski, and S. D. Fink, (2005) "Strontium and Actinide Separations from High Level Nuclear Waste Solutions Using Monosodium Titanate 1. Simulant Testing." Separation Science and Technology, 40 (15): 3093.

3. M. Nyman, and D. T. Hobbs, (2006) "A Family of Peroxo-titanate Materials Tailored for Optimal Strontium and Actinide Sorption.” Chem. Mater. 18 (26): 6425. 
SRNL-STI-2012-00193

Revision 0

Appendix A. Batch Contact Testing Results 
Table A-1. Summary of DFs obtained in varying ionic strength simulants.

\begin{tabular}{|c|c|c|c|c|c|c|c|c|}
\hline Test ID & ET-2 & ET-5 & ET-7 & ET-9 & ET-11 & ET-13 & ET-3 & ET-14 \\
\hline Sorbent & ${ }^{\mathrm{E}} \mathrm{MST}$ & ${ }^{\mathrm{E}} \mathrm{MST}$ & ${ }^{\mathrm{E}} \mathrm{MST}$ & ${ }^{\mathrm{E}} \mathrm{MST}$ & ${ }^{\mathrm{E}} \mathrm{MST}$ & ${ }^{\mathrm{E}} \mathrm{MST}$ & MST & MST \\
\hline $\begin{array}{c}\text { Target } \\
{[\mathrm{Na}](\mathrm{M})}\end{array}$ & 5.6 & 6.0 & 6.5 & 7.0 & 7.5 & 8.0 & 5.6 & 8.0 \\
\hline $\begin{array}{l}\text { Measured } \\
{[\mathrm{Na} \text { (M) }}\end{array}$ & 5.39 & 5.65 & 5.79 & 5.92 & 6.44 & 6.83 & 5.39 & 6.83 \\
\hline & \multicolumn{8}{|c|}{${ }^{85} \mathrm{Sr} \mathrm{DF}$} \\
\hline 6-h & 6.05 & 1.84 & 2.03 & 2.55 & 1.74 & 1.65 & 46.0 & 19.6 \\
\hline 30-h & 21.0 & 6.12 & 3.70 & 6.50 & 3.14 & 4.19 & 83.5 & 25.2 \\
\hline 120-h & 71.4 & 23.7 & 16.1 & 23.9 & 13.0 & 29.1 & 108 & 30.4 \\
\hline \multirow[t]{2}{*}{ 191-h } & 121 & 46.7 & 18.9 & 28.6 & 16.7 & 16.2 & 101 & 35.3 \\
\hline & \multicolumn{8}{|c|}{ Pu DF } \\
\hline 6-h & 1.53 & 1.24 & 1.25 & 1.56 & 1.22 & 0.918 & 2.62 & 2.51 \\
\hline 30-h & 2.96 & 2.30 & 1.65 & 2.29 & 1.90 & 2.24 & 4.36 & 4.22 \\
\hline 120-h & 9.45 & 5.54 & 4.03 & 4.28 & 3.59 & 5.24 & 8.51 & 7.46 \\
\hline \multirow[t]{2}{*}{ 191-h } & 14.5 & 10.5 & 5.69 & 5.05 & 4.00 & 4.32 & 12.4 & 10.5 \\
\hline & \multicolumn{8}{|c|}{ Np DF } \\
\hline 6-h & 1.29 & 1.10 & 1.09 & 1.18 & 1.12 & 1.15 & 1.14 & 2.62 \\
\hline 30-h & 2.22 & 1.38 & 1.22 & 1.48 & 1.55 & 1.89 & 1.63 & 4.65 \\
\hline 120-h & $>7.75$ & 3.51 & 2.51 & 2.04 & 2.90 & 3.86 & 2.69 & 4.80 \\
\hline \multirow[t]{2}{*}{ 191-h } & $>7.40$ & 5.75 & 2.92 & 2.82 & 4.65 & 5.47 & 3.15 & 8.02 \\
\hline & \multicolumn{8}{|c|}{ U DF } \\
\hline 6-h & 1.23 & 1.13 & 1.11 & 1.23 & 1.10 & 0.991 & 1.11 & 1.06 \\
\hline 30-h & 1.90 & 1.35 & 1.20 & 1.47 & 1.26 & 1.33 & 1.25 & 1.27 \\
\hline 120-h & 3.67 & 1.74 & 1.81 & 1.65 & 1.50 & 1.82 & 1.53 & 1.31 \\
\hline 191-h & 4.44 & 2.38 & 1.84 & 1.73 & 1.62 & 1.78 & 1.47 & 1.47 \\
\hline
\end{tabular}


SRNL-STI-2012-00193

Revision 0

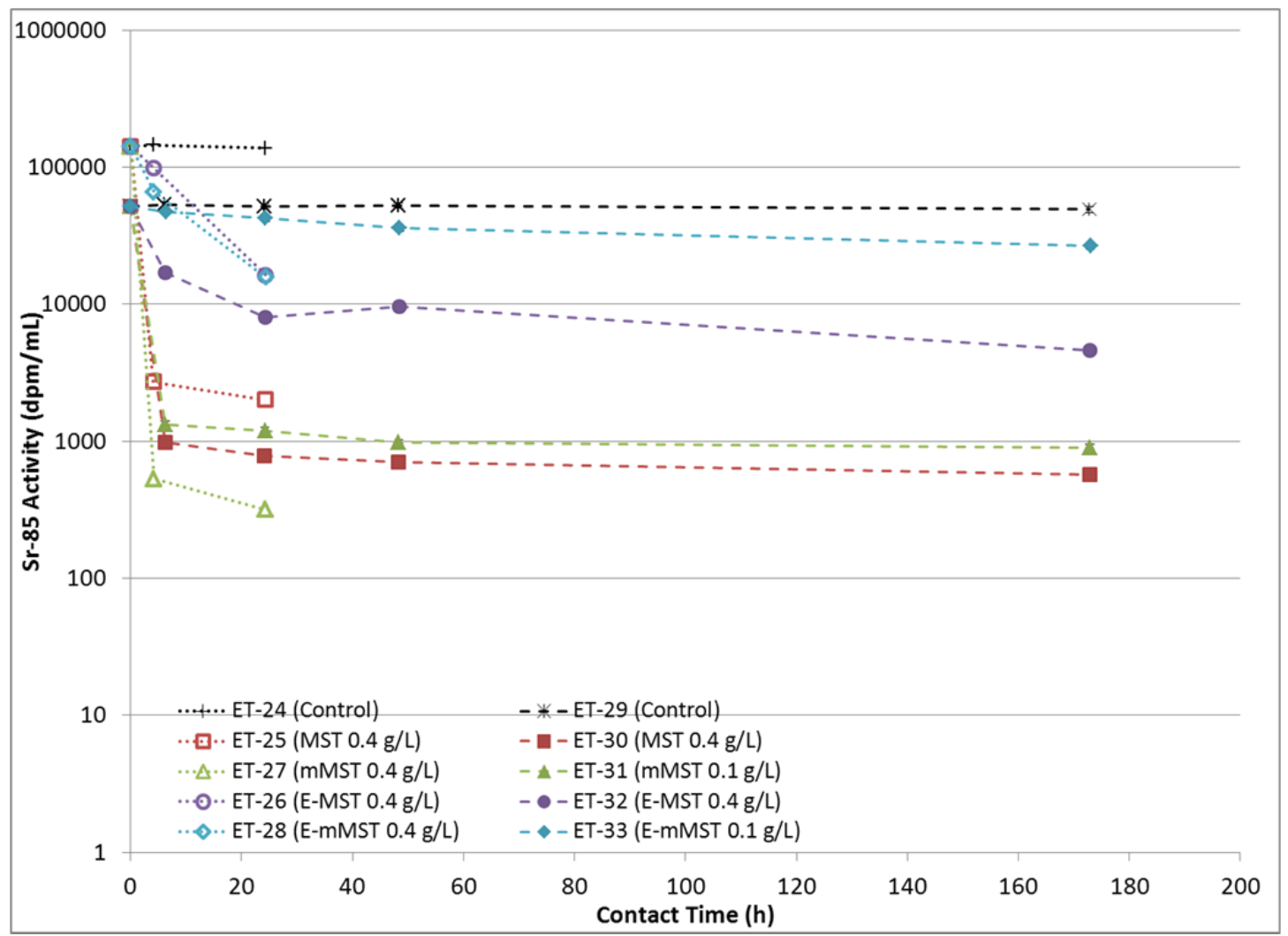

Figure A-1. ${ }^{85} \mathrm{Sr}$ activity versus contact time for Tests ET-24 through ET-33.

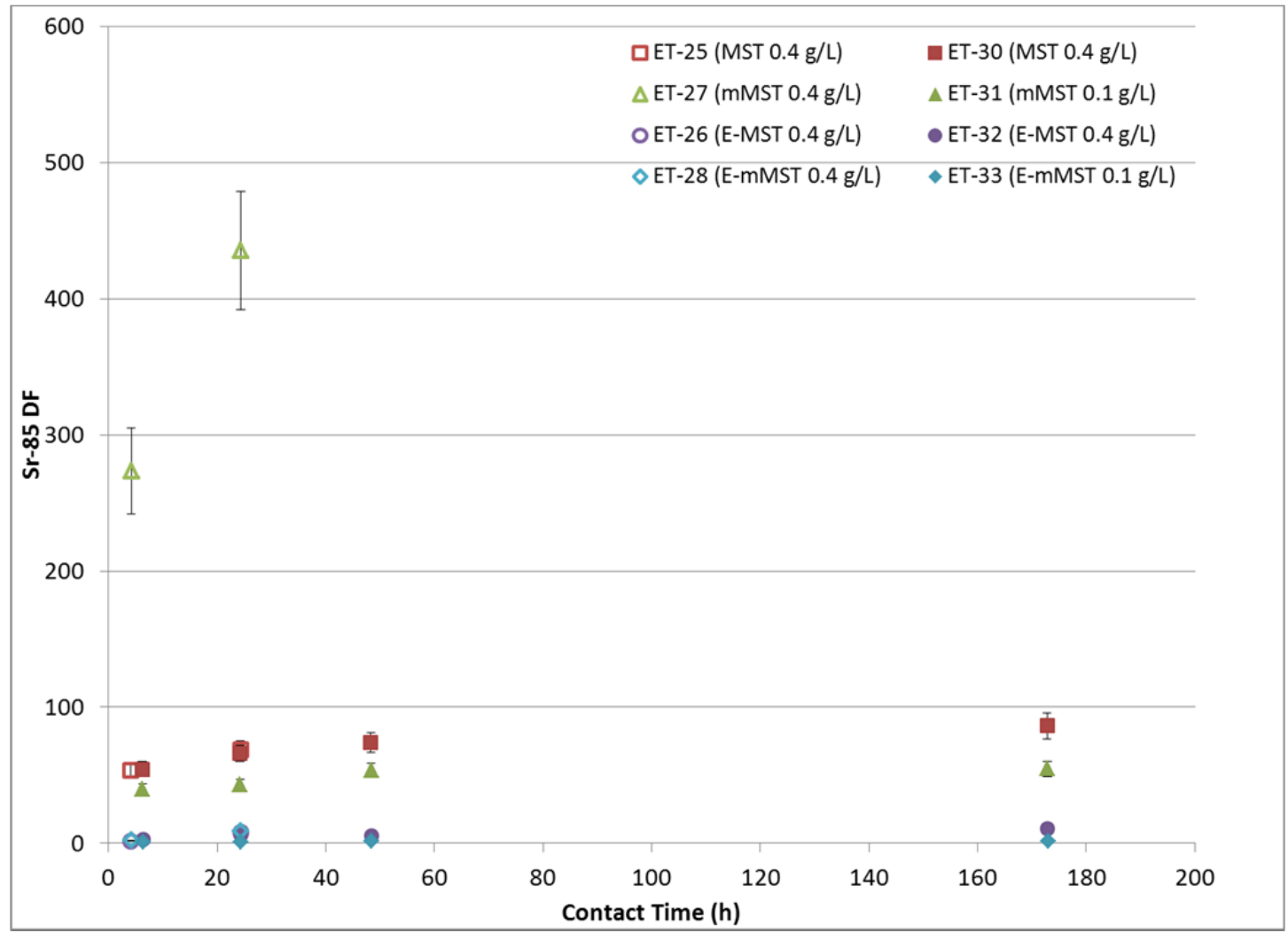

Figure A-2. ${ }^{85} \mathrm{Sr}$ DF versus contact time for Tests ET-25 through ET-33. 
SRNL-STI-2012-00193

Revision 0

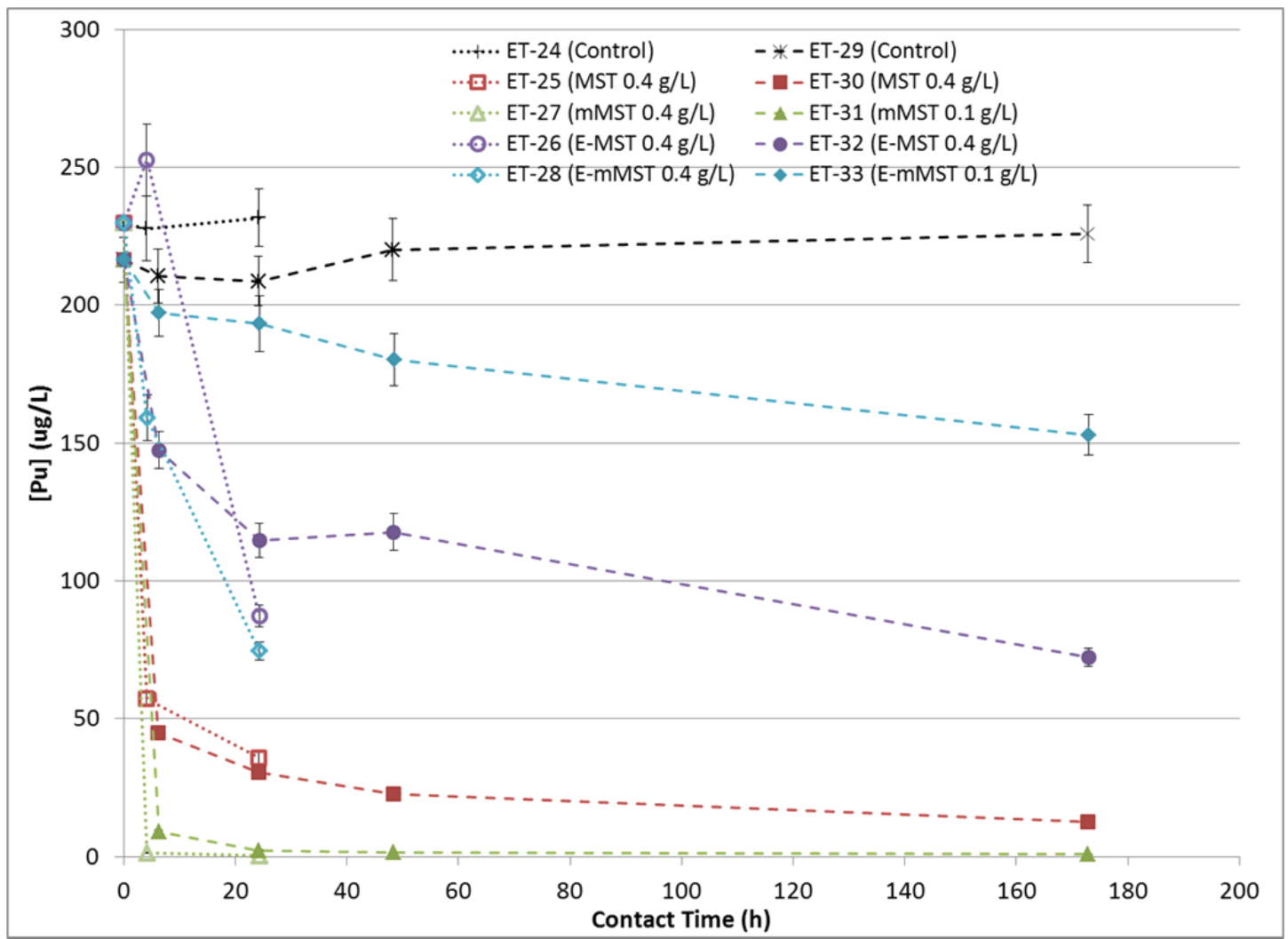

Figure A-3. Pu concentration versus contact time for Tests ET-24 through ET-33.

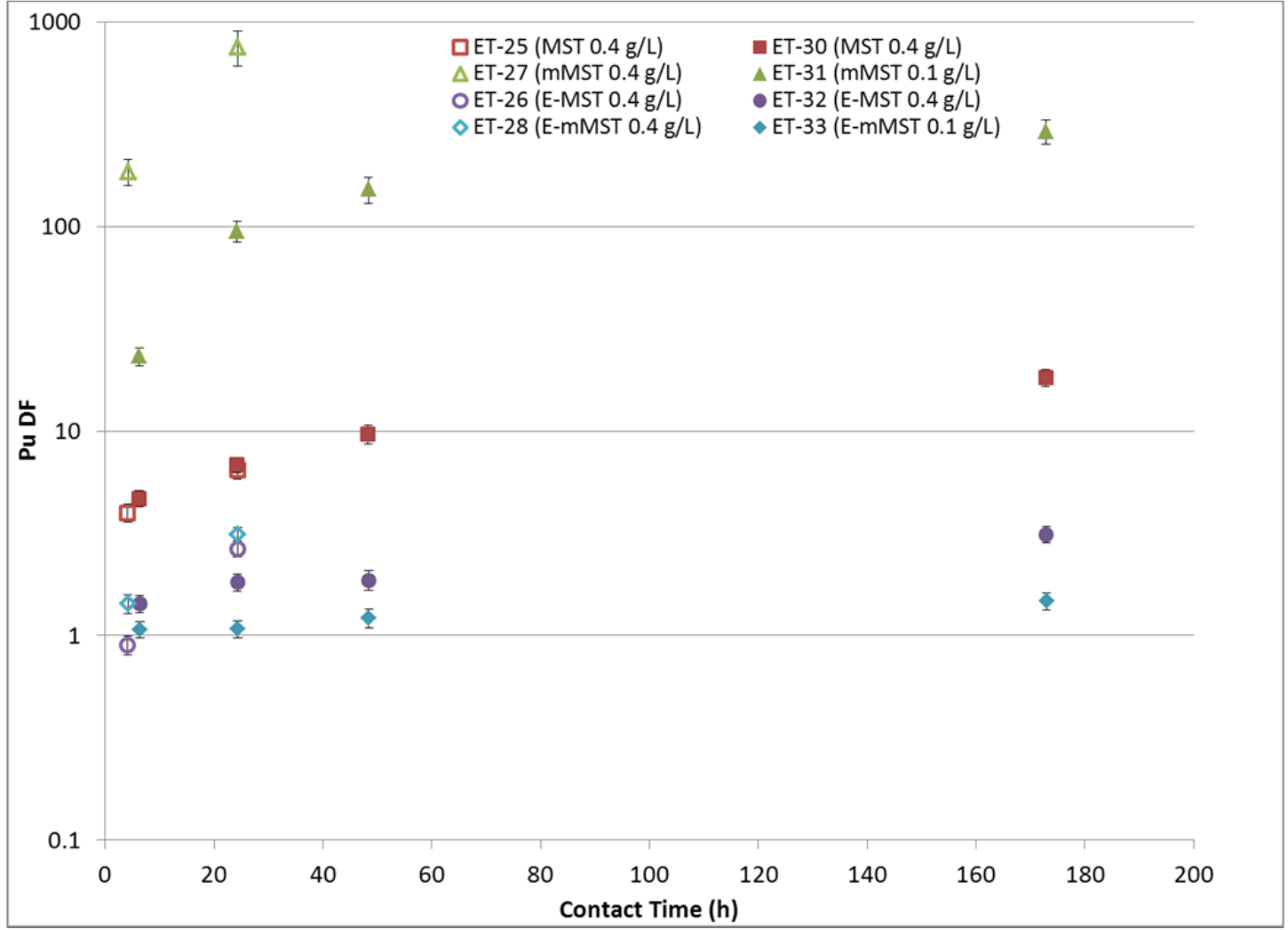

Figure A-4. Pu DF versus contact time for Tests ET-25 through ET-33. 


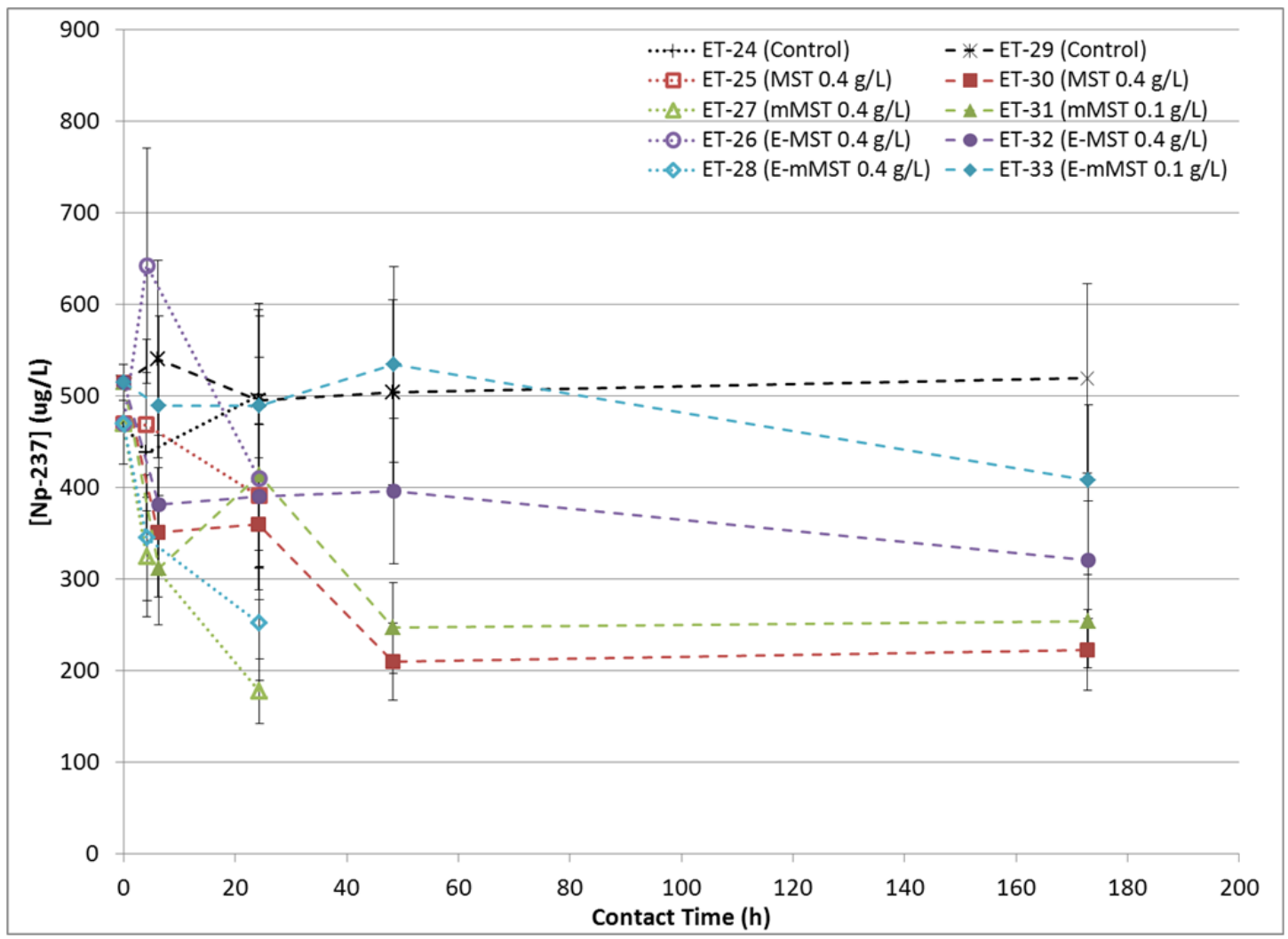

Figure A-5. ${ }^{237} \mathrm{~Np}$ concentration versus contact time for Tests ET-24 through ET-33.

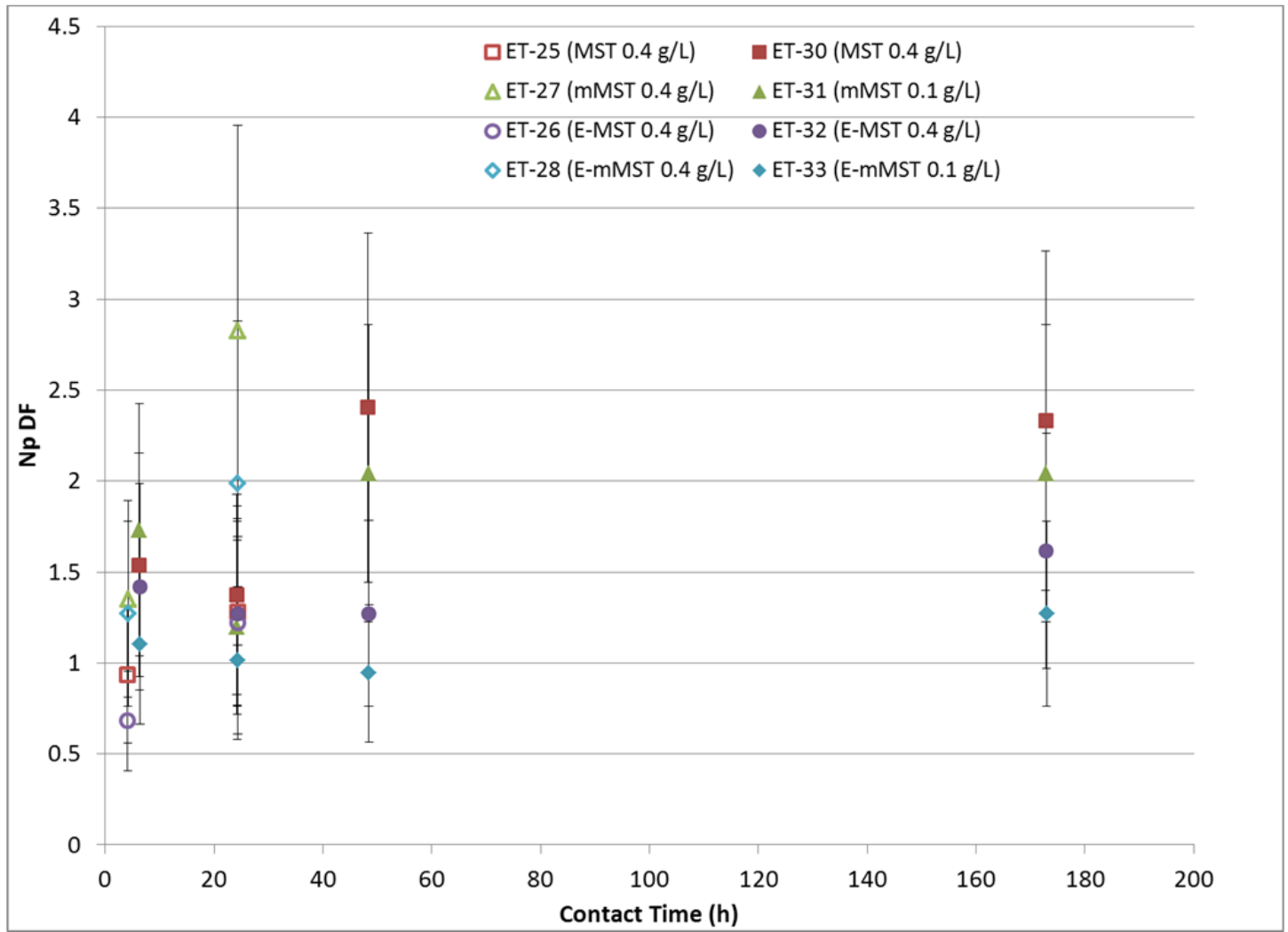

Figure A-6. ${ }^{237} \mathrm{~Np}$ DF versus contact time for Tests ET-25 through ET-33. 
SRNL-STI-2012-00193

Revision 0

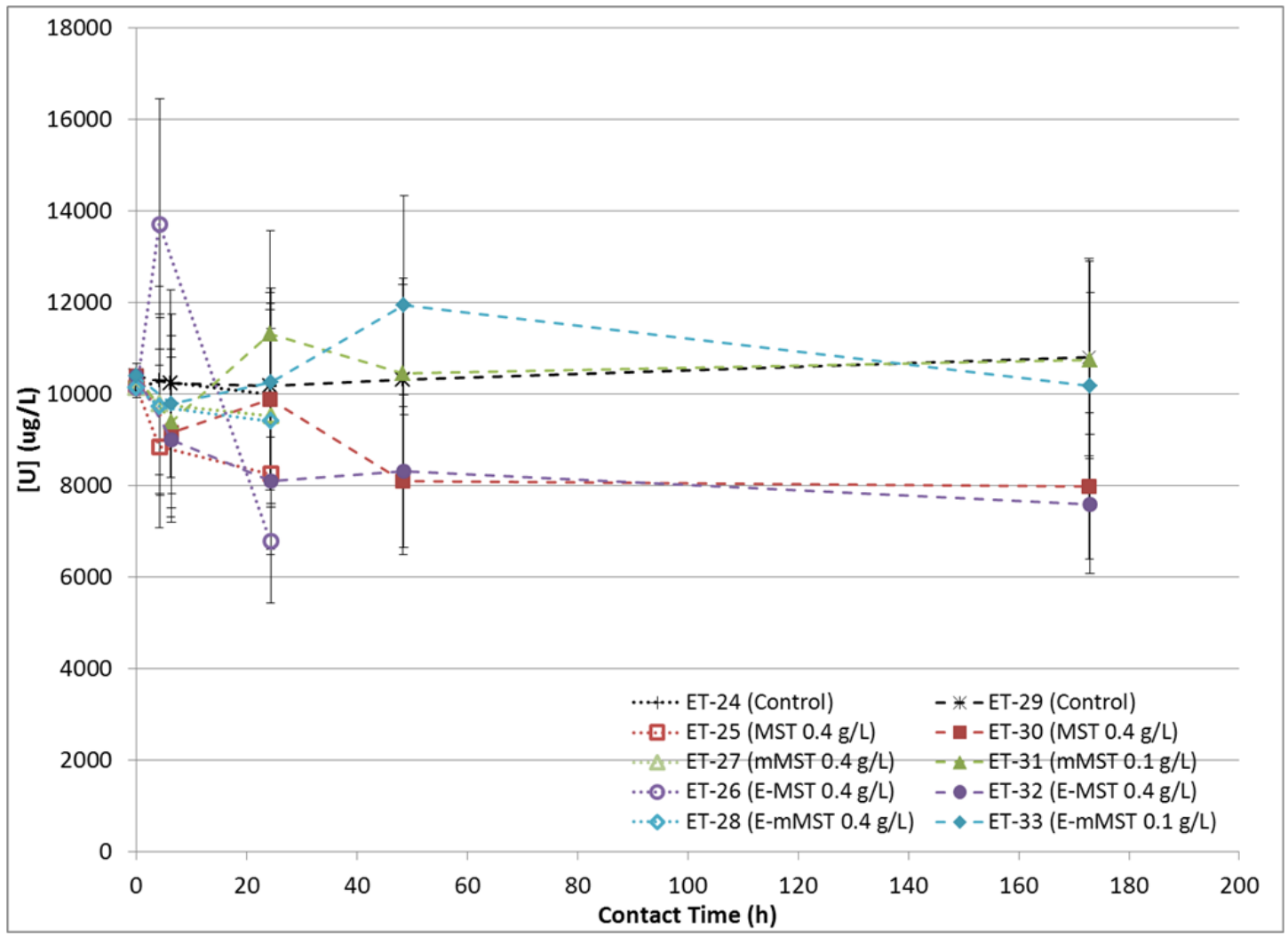

Figure A-7. U concentration versus contact time for Tests ET-24 through ET-33.

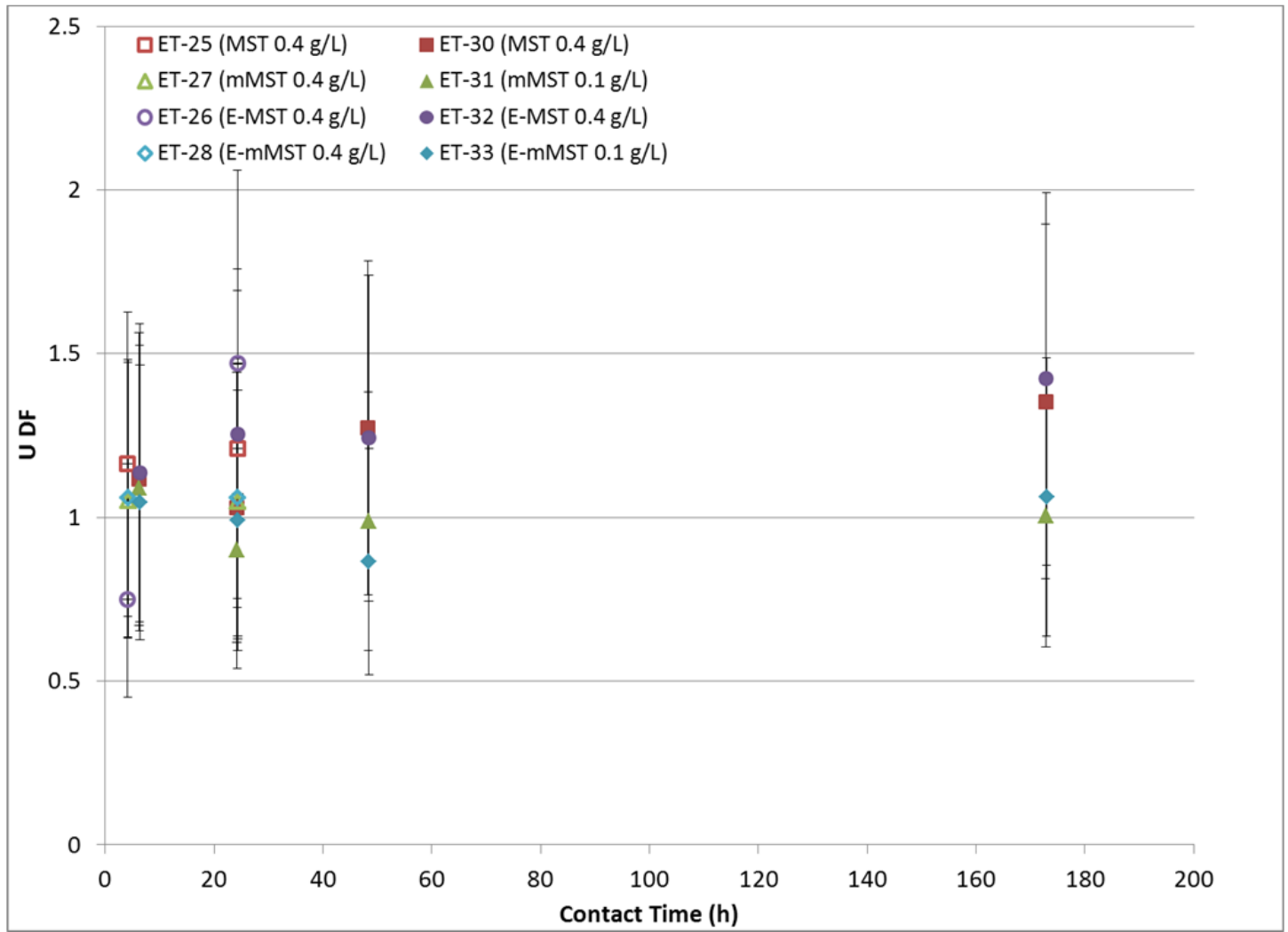

Figure A-8. U DF versus contact time for Tests ET-25 through ET-33. 
SRNL-STI-2012-00193

Revision 0

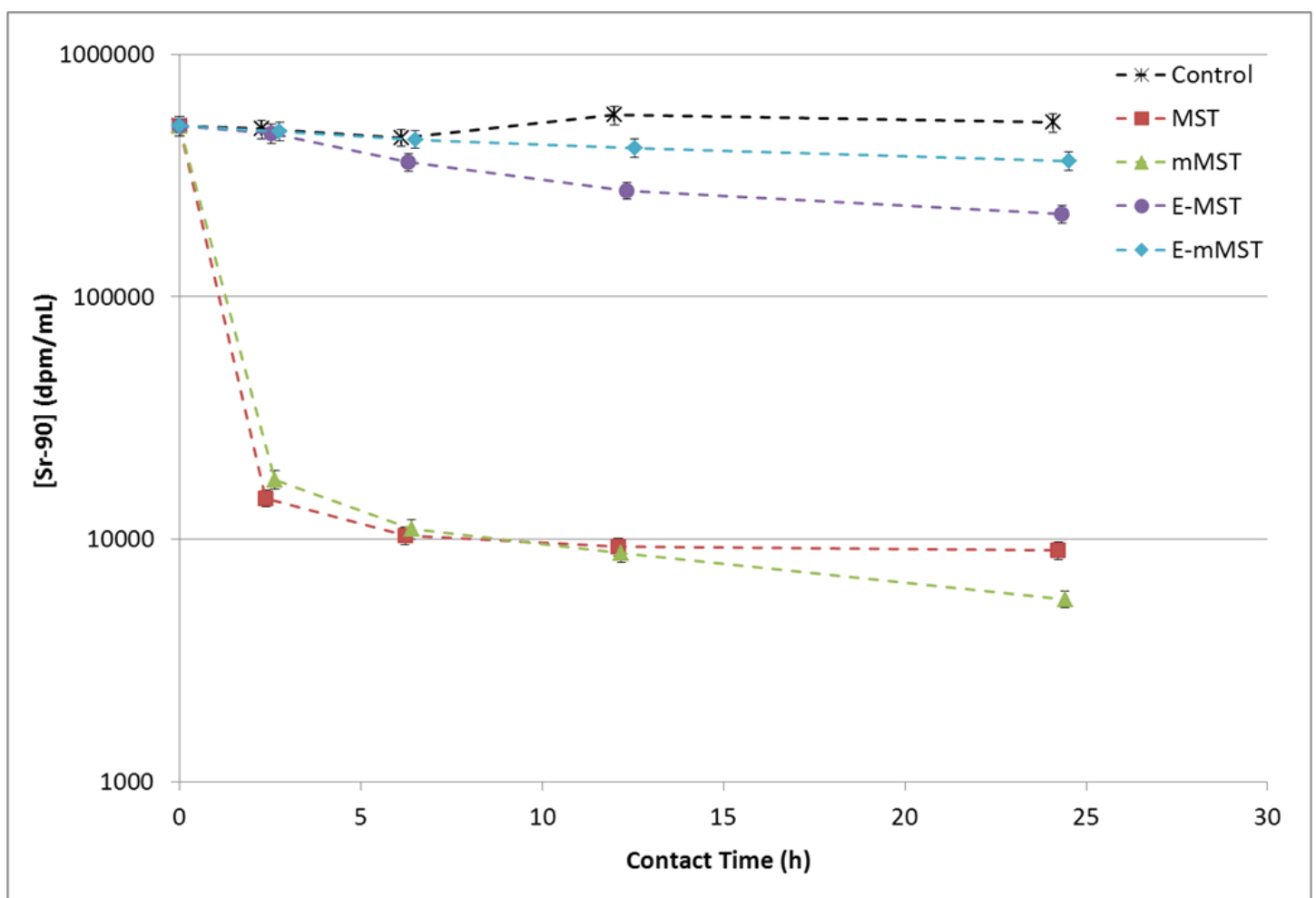

Figure A-9. ${ }^{90} \mathrm{Sr}$ activity versus contact time for real waste tests.

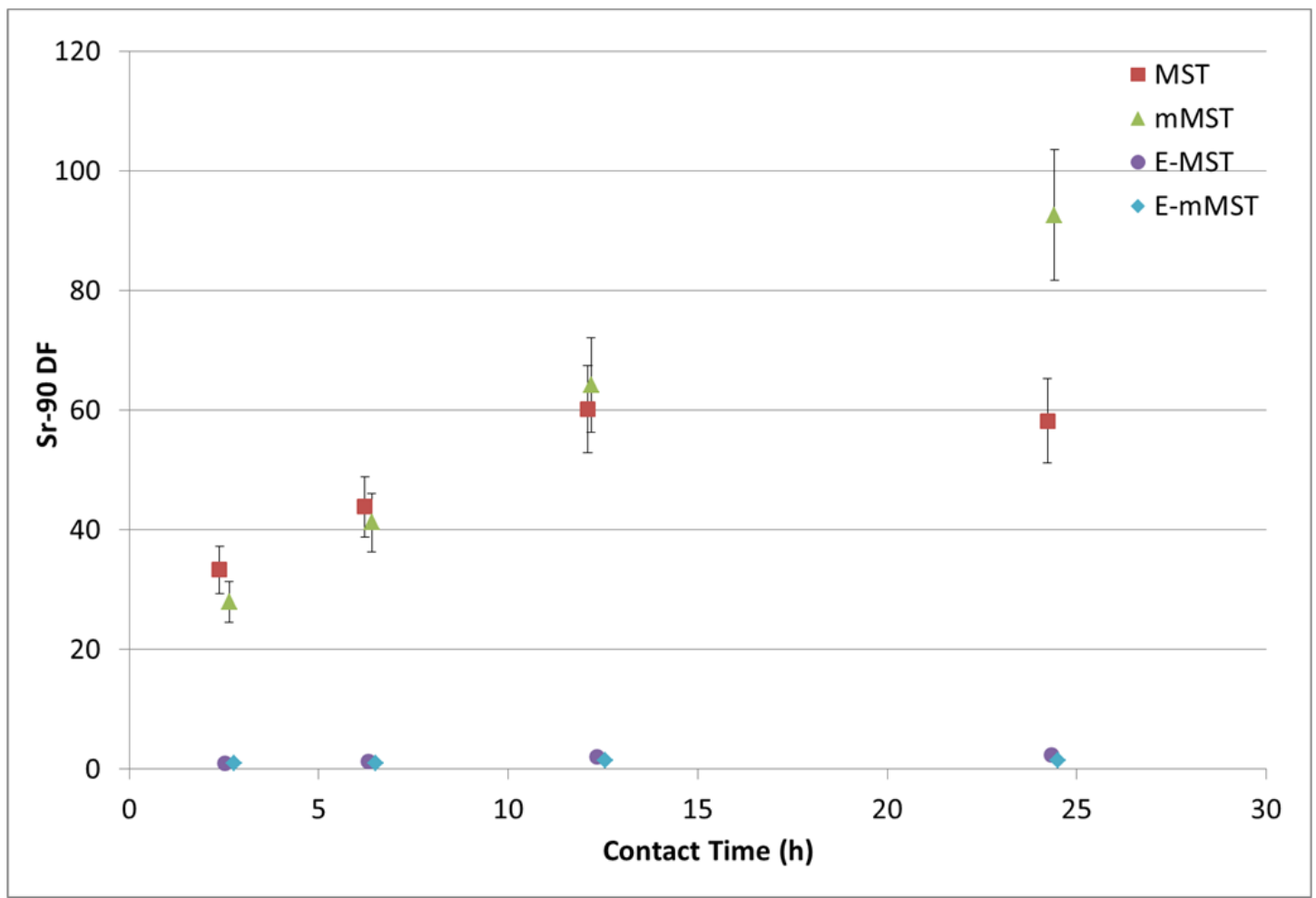

Figure A-10. ${ }^{90} \mathrm{Sr}$ DF versus contact time for real waste tests. 
SRNL-STI-2012-00193

Revision 0

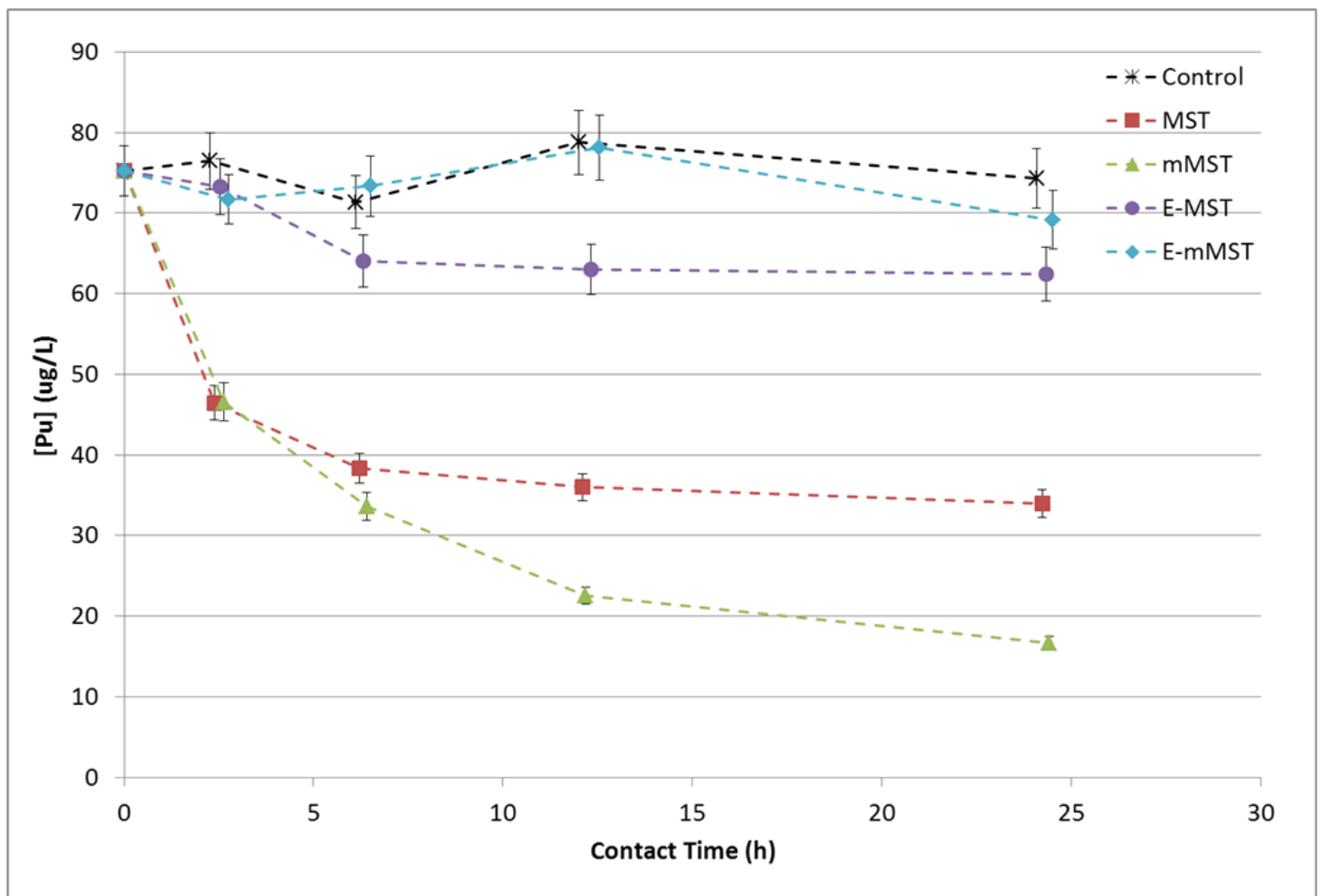

Figure A-11. Pu concentration versus contact time for real waste tests.

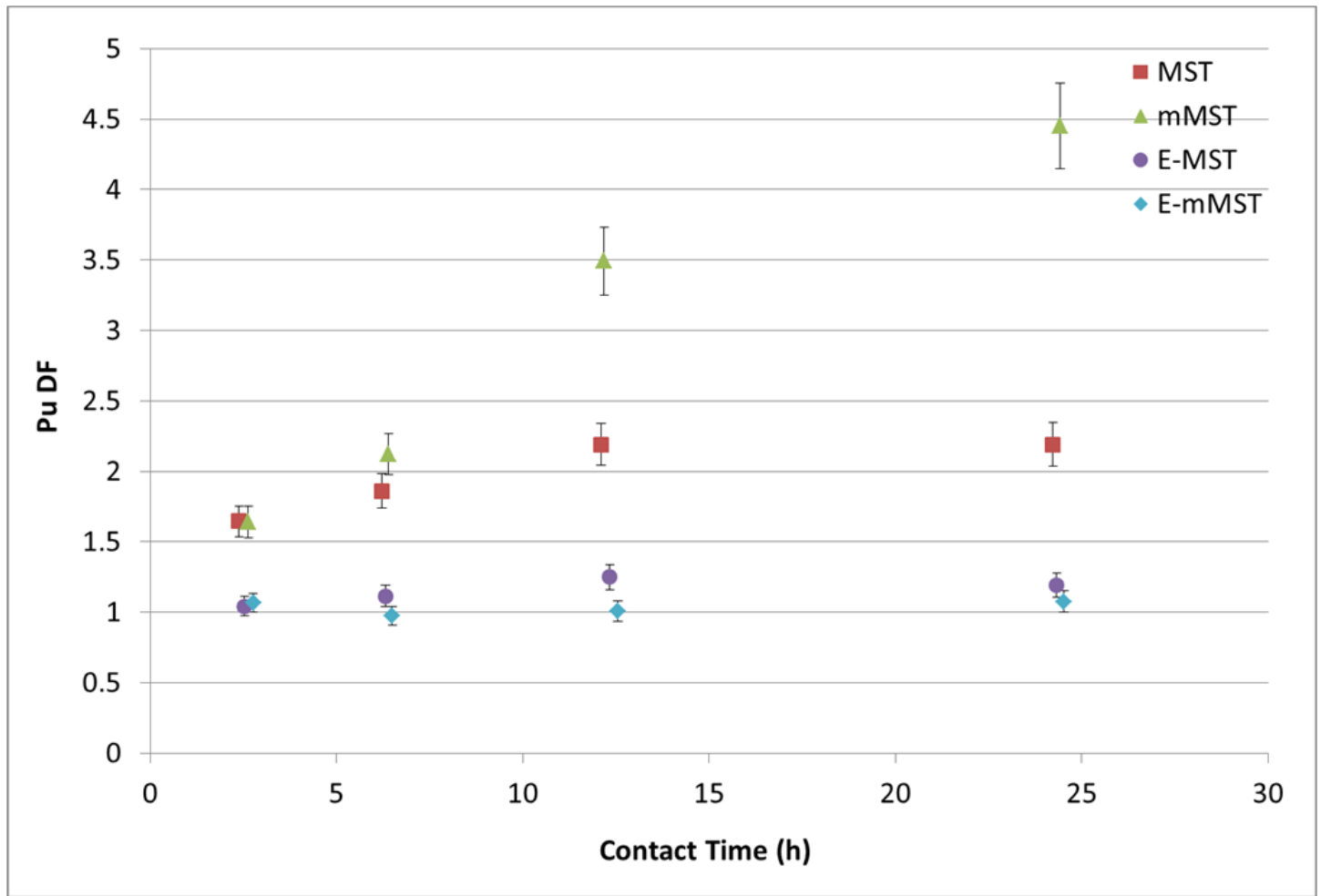

Figure A-12. Pu DF versus contact time for real waste tests. 
SRNL-STI-2012-00193

Revision 0

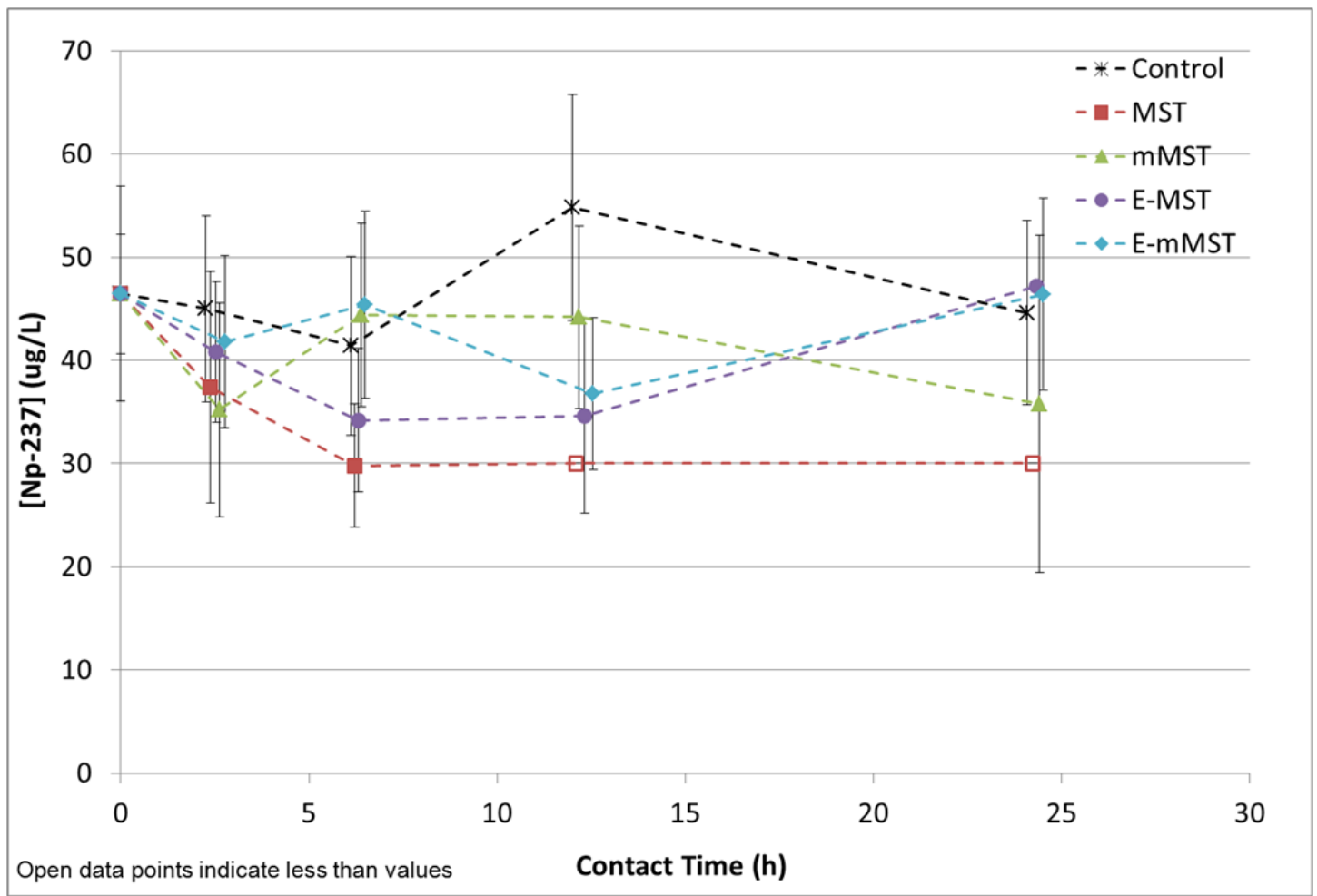

Figure A-13. ${ }^{237} \mathrm{~Np}$ concentration versus contact time for real waste tests.

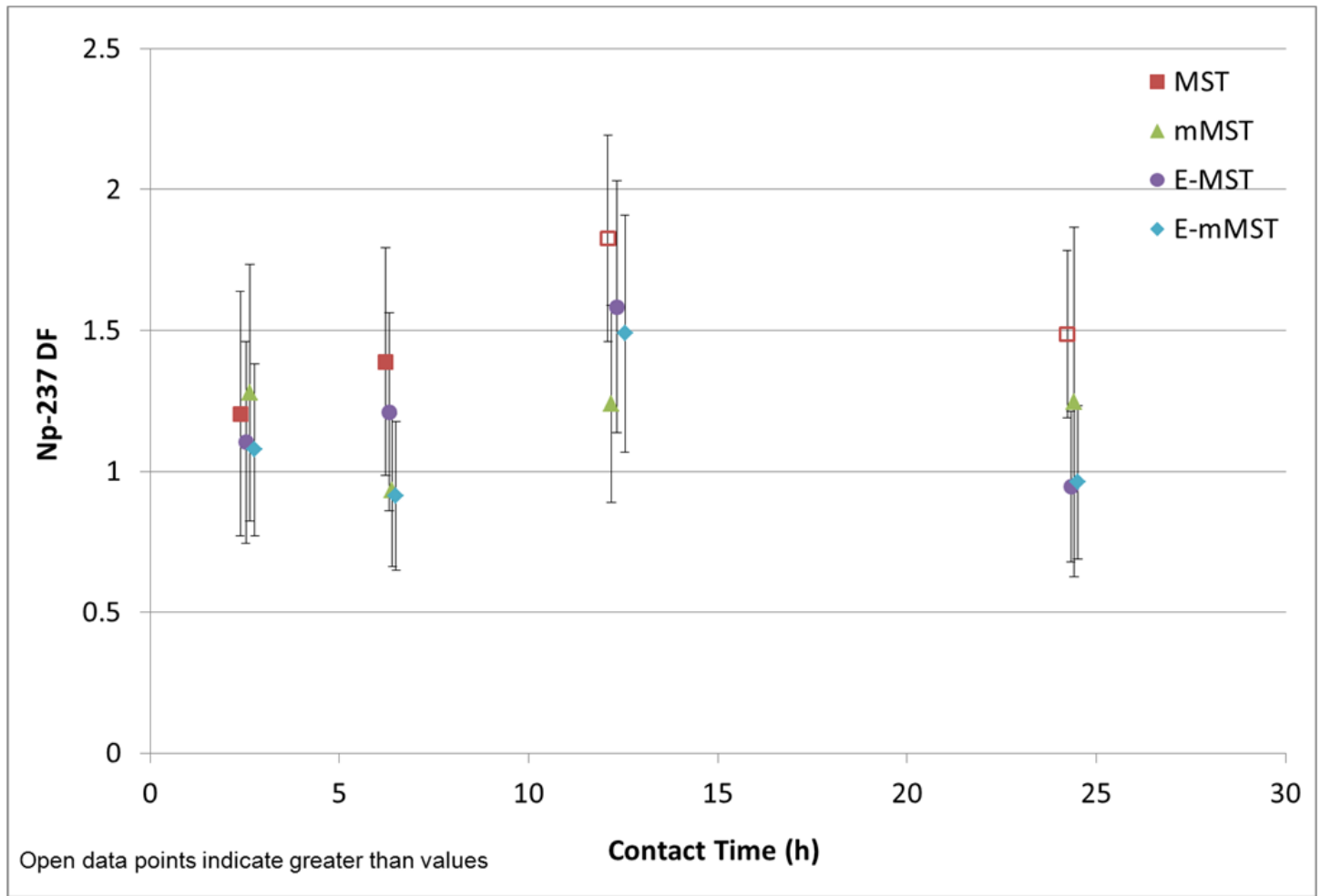

Figure A-14. ${ }^{237} \mathrm{~Np}$ DF versus contact time for real waste tests. 
SRNL-STI-2012-00193

Revision 0

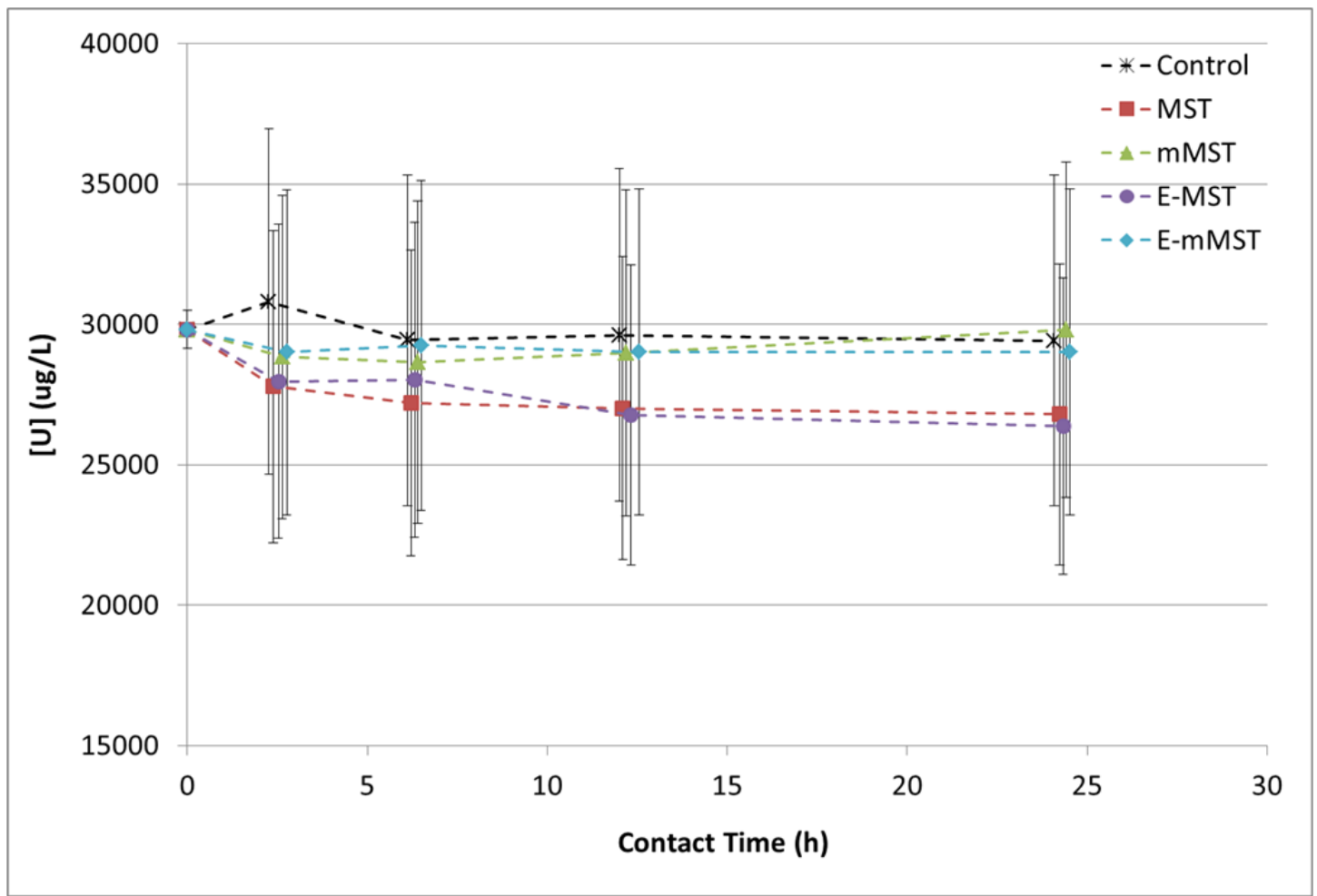

Figure A-15. U concentration versus contact time for real waste tests.

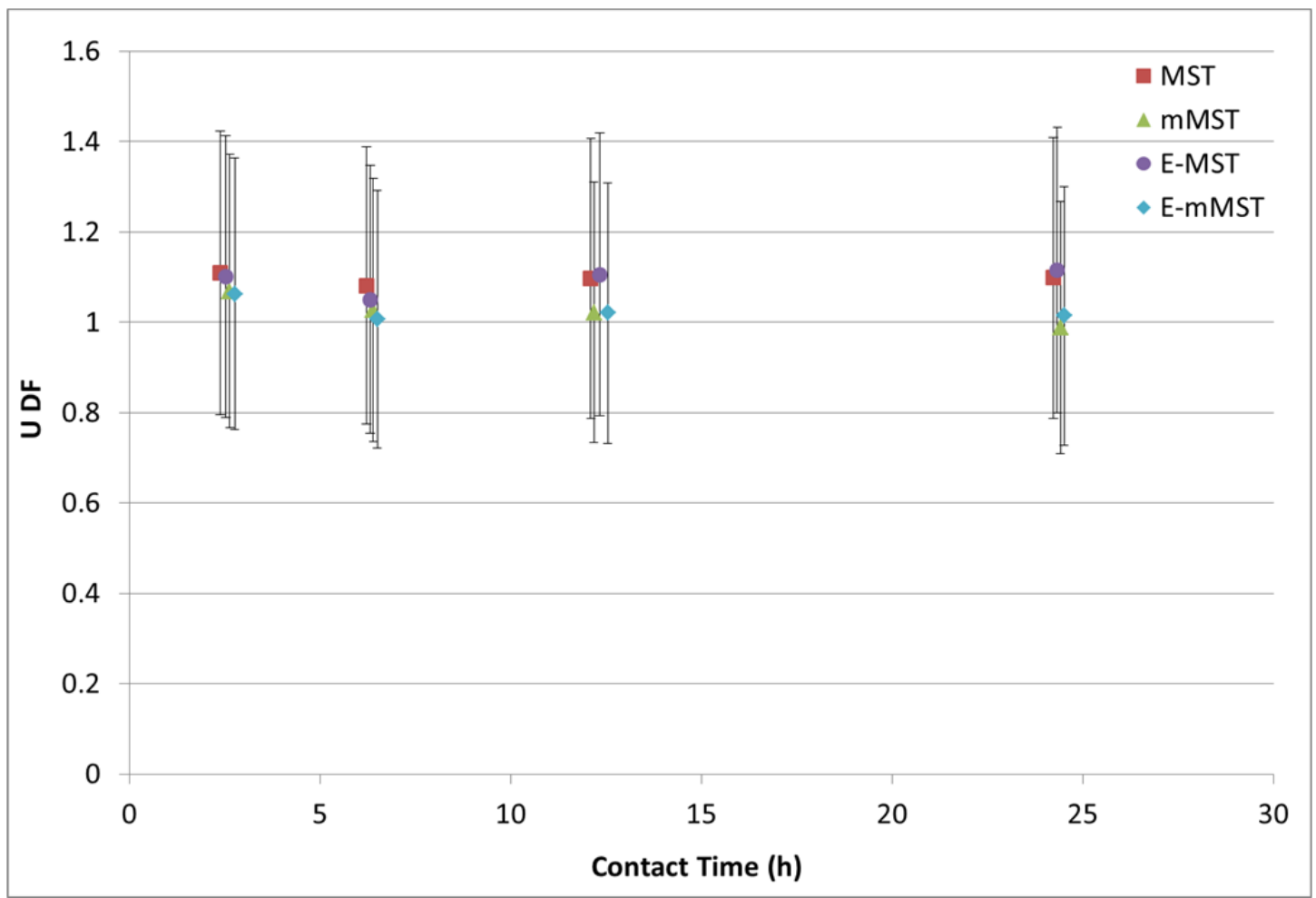

Figure A-16. U DF versus contact time for real waste tests. 
SRNL-STI-2012-00193

Revision 0

Appendix B. Column Data 
SRNL-STI-2012-00193

Revision 0

Table B-1. Data from Column 1 ( $\left.{ }^{\mathrm{E}} \mathrm{MST}\right)$.

\begin{tabular}{|c|c|c|c|c|c|}
\hline Sample ID & Date/Time & $\begin{array}{c}\text { Column } \\
\text { Temp. }\left({ }^{\circ} \mathrm{C}\right)\end{array}$ & $\begin{array}{c}\text { Ave. Flow Rate } \\
\text { (mL/min) }\end{array}$ & $\begin{array}{c}\text { Bed Volumes } \\
\text { Passed }\end{array}$ & $\begin{array}{c}\text { Volume } \\
\text { Passed }(\mathrm{mL})\end{array}$ \\
\hline Startup & $9 / 2 / 1113: 15$ & 25.5 & $\mathrm{n} / \mathrm{a}$ & 0 & 0 \\
\hline Column 1-1A & 9/6/11 10:05 & 26.8 & 0.474 & 690 & 2819 \\
\hline Column 1 - 1B & $9 / 6 / 1115: 51$ & 26.7 & 0.500 & 732 & 2991 \\
\hline Column 1-2A & $9 / 7 / 119: 36$ & - & 0.510 & 864 & 3533 \\
\hline Column 1 - 2B & 9/7/11 16:26 & 27.2 & 0.508 & 916 & 3743 \\
\hline Column 1-3A & 9/8/119:56 & 26.4 & 0.509 & 1046 & 4276 \\
\hline Column 1 - 3B & 9/8/11 14:55 & 26.9 & 0.510 & 1084 & 4430 \\
\hline Column 1 - 4A & 9/9/119:19 & 26.4 & 0.512 & 1222 & 4993 \\
\hline Column 1-4B & 9/9/11 14:20 & 27.0 & 0.513 & 1259 & 5147 \\
\hline Column 1 - 5A & 9/12/11 9:27 & 27.0 & 0.512 & 1764 & 7207 \\
\hline Column 1 - 5B & $9 / 12 / 1114: 44$ & 25.2 & 0.510 & 1803 & 7369 \\
\hline Column 1-6A & 9/13/11 10:48 & 26.6 & 0.508 & 1953 & 7982 \\
\hline Column 1 - 6B & 9/13/11 15:47 & 29.7 & 0.506 & 1990 & 8133 \\
\hline Column 1 - 7A & $9 / 14 / 119: 55$ & 26.2 & 0.509 & 2125 & 8685 \\
\hline Column 1 - 7B & $9 / 14 / 1114: 50$ & 29.5 & 0.507 & 2162 & 8835 \\
\hline Column 1 - 8A & 9/15/11 9:39 & 30.2 & 0.507 & 2302 & 9407 \\
\hline Column 1 - 8B & $9 / 15 / 1115: 16$ & 30.9 & 0.503 & 2344 & 9578 \\
\hline Column 1-9A & $9 / 16 / 118: 47$ & 27.3 & 0.510 & 2475 & 10114 \\
\hline Column 1 - 9B & $9 / 16 / 1114: 16$ & 25.1 & 0.497 & 2515 & 10278 \\
\hline Column 1 - 10A & 9/19/11 9:21 & 24.3 & 0.520 & 3028 & 12373 \\
\hline Column 1 - 10B & $9 / 19 / 1114: 59$ & 24.5 & 0.521 & 3071 & 12548 \\
\hline Column 1 - 11A & 9/20/11 9:14 & 25.0 & 0.508 & 3207 & 13103 \\
\hline Column 1 - 11B & $9 / 20 / 1114: 51$ & 27.6 & 0.519 & 3249 & 13278 \\
\hline Column 1 - 12A & $9 / 21 / 1110: 35$ & 25.8 & 0.508 & 3397 & 13880 \\
\hline Column 1 - 12B & 9/21/11 15:01 & 27.2 & 0.501 & 3429 & 14013 \\
\hline Column 1 - 13A & 9/22/11 10:01 & 25.1 & $0.413^{*}$ & 3545 & 14485 \\
\hline Column 1 - 13B & $9 / 22 / 1114: 33$ & 27.0 & 0.509 & 3578 & 14623 \\
\hline Average & $\mathrm{n} / \mathrm{a}$ & 26.8 & 0.508 & $\mathrm{n} / \mathrm{a}$ & $\mathrm{n} / \mathrm{a}$ \\
\hline
\end{tabular}

Column flow stopped sometime overnight due to low level in feed carboy (not included in average). 
SRNL-STI-2012-00193

Revision 0

Table B-2. Data from Column $2\left(\mathrm{H}_{2} \mathrm{O}_{2}\right.$ treated $\left.{ }^{\mathrm{E}} \mathrm{mMST}\right)$.

\begin{tabular}{|c|c|c|c|c|c||}
\hline Sample ID & Date/Time & $\begin{array}{c}\text { Column } \\
\text { Temp. }\left({ }^{\circ} \mathbf{C}\right)\end{array}$ & $\begin{array}{c}\text { Ave. Flow Rate } \\
(\mathbf{m L} / \mathbf{m i n})\end{array}$ & $\begin{array}{c}\text { Bed Volumes } \\
\text { Passed }\end{array}$ & $\begin{array}{c}\text { Volume } \\
\text { Passed (mL) }\end{array}$ \\
\hline Startup & $9 / 2 / 1113: 15$ & 25.5 & $\mathrm{n} / \mathrm{a}$ & 0 & 0 \\
\hline Column 2 - 1A & $9 / 6 / 119: 39$ & 26.9 & 0.471 & 1411 & 2816 \\
\hline Column 2 - 1B & $9 / 6 / 1115: 37$ & 26.8 & 0.498 & 1498 & 2989 \\
\hline Column 2 - 2A & $9 / 7 / 119: 20$ & - & 0.497 & 1762 & 3517 \\
\hline Column 2 - 2B & $9 / 7 / 1116: 12$ & 27.4 & 0.498 & 1866 & 3723 \\
\hline Column 2 - 3A & $9 / 8 / 119: 43$ & 26.5 & 0.494 & 2126 & 4242 \\
\hline Column 2 - 3B & $9 / 8 / 1114: 42$ & 27.0 & 0.495 & 2200 & 4390 \\
\hline Column 2 -4A & $9 / 9 / 119: 07$ & 26.6 & 0.494 & 2473 & 4936 \\
\hline Column 2 - 4B & $9 / 9 / 1114: 10$ & 27.1 & 0.494 & 2548 & 5085 \\
\hline Column 2 - 5A & $9 / 12 / 119: 16$ & 27.1 & 0.490 & 3535 & 7055 \\
\hline Column 2 - 5B & $9 / 12 / 1114: 30$ & 25.3 & 0.500 & 3615 & 7214 \\
\hline Column 2 - 6A & $9 / 13 / 1110: 37$ & 26.7 & 0.520 & 3929 & 7840 \\
\hline Column 2 - 6B & $9 / 13 / 1115: 34$ & 29.8 & 0.533 & 4008 & 7999 \\
\hline Column 2 - 7A & $9 / 14 / 119: 44$ & 26.3 & 0.534 & 4299 & 8580 \\
\hline Column 2 - 7B & $9 / 14 / 1114: 39$ & 29.7 & 0.532 & 4378 & 8738 \\
\hline Column 2 - 8A & $9 / 15 / 119: 27$ & 30.3 & 0.530 & 4677 & 9335 \\
\hline Column 2 - 8B & $9 / 15 / 1115: 04$ & 31.0 & 0.529 & 4767 & 9513 \\
\hline Column 2 - 9A & $9 / 16 / 118: 34$ & 27.2 & 0.537 & 5048 & 10075 \\
\hline Column 2 - 9B & $9 / 16 / 1114: 05$ & 25.0 & 0.537 & 5138 & 10253 \\
\hline Column 2 - 10A & $9 / 19 / 119: 37$ & 24.3 & 0.535 & 6224 & 12420 \\
\hline Column 2 - 10B & $9 / 19 / 1114: 48$ & 24.6 & 0.492 & 6300 & 12573 \\
\hline Column 2 - 11A & $9 / 20 / 119: 05$ & 25.0 & 0.485 & 6566 & 13104 \\
\hline Column 2 - 11B & $9 / 20 / 1114: 38$ & 27.7 & 0.488 & 6648 & 13268 \\
\hline Column 2 - 12A & $9 / 21 / 1110: 23$ & 25.8 & 0.481 & 6934 & 13838 \\
\hline Average & n/a & $\mathbf{2 6 . 9}$ & $\mathbf{0 . 5 0 7}$ & $\mathrm{n} / \mathrm{a}$ & $\mathrm{n} / \mathrm{a}$ \\
\hline \hline
\end{tabular}




\section{Distribution:}

K. M. Fox, 999-W

A. P. Fellinger, 773-41A

S. D. Fink, 773-A

B. J. Giddings, 786-5A

C. C. Herman, 999-W

S. L. Marra, 773-A

F. M. Pennebaker, 773-42A

W. R. Wilmarth, 773-A

K. M. L. Taylor-Pashow, 773-A

C. A. Nash, 773-42A

D. T. Hobbs, 773-A

F. F. Fondeur, 773-A

M. T. Keefer, 766-H

J. W. Ray, 704-S

H. B. Shah, 766-H

D. C. Sherburne, 704-S

A. V. Staub, 704-27S

P. R. Jackson, DOE-SR, 703-46A

K. H. Subramanian, 766-H

C. E. Duffey, 704-61H

D. J. Martin, 241-152H

K. L. Lang, 241-152H

E. J. Freed, 704-56H

M. W. Geeting, 241-152H

S. P. McLeskey, 704-27S

T. H. Huff, 707-13E

R. E. Edwards, 766-H

P. C. Suggs, 704-S

K. D. Harp, 766-H 